UNIVERSIDADE DE SÃO PAULO

FACULDADE DE FILOSOFIA, LETRAS E CIÊNCIAS HUMANAS DEPARTAMENTO DE LETRAS MODERNAS

PROGRAMA DE PÓS-GRADUAÇÃO EM ESTUDOS LINGUÍSTICOS, LITERÁRIOS E TRADUTOLÓGICOS EM FRANCÊS

ANDREI FERNANDO FERREIRA LIMA

Édouard Glissant e a questão identitária antilhana

Versão corrigida

SÃO PAULO 


\title{
Édouard Glissant e a questão identitária antilhana
}

\begin{abstract}
Dissertação de mestrado apresentada ao Departamento de Letras Modernas da Faculdade de Filosofia, Letras e Ciências Humanas da Universidade de São Paulo para obtenção do título de Mestre em Letras.

Área de concentração: Estudos Linguísticos, Literários e Tradutológicos em Francês.

Orientador: Prof. ${ }^{a}$ Dr. ${ }^{a}$ Véronique Marie Braun Dahlet
\end{abstract}

Versão corrigida 
Autorizo a reprodução e divulgação total ou parcial deste trabalho, por qualquer meio convencional ou eletrônico, para fins de estudo e pesquisa, desde que citada a fonte.

Catalogação na Publicação

Serviço de Biblioteca e Documentação

Faculdade de Filosofia, Letras e Ciências Humanas da Universidade de São Paulo

L732É Lima, Andrei Fernando Ferreira

Edouard Glissant e a questão identitária antilhana

/ Andrei Fernando Ferreira Lima ; orientadora

Véronique Marie Braun Dahlet. - São Paulo, 2017.

$109 \mathrm{f}$

Dissertação (Mestrado) - Faculdade de Filosofia, Letras e Ciências Humanas da Universidade de São Paulo. Departamento de Letras Modernas. Área de concentração: Estudos Linguísticos, Literários e Tradutológicos em Francês.

1. Identidade. 2. Cultura. 3. Língua. 4. Antilhas. 5. Édouard Glissant. I. Dahlet, Véronique Marie Braun, orient. II. Título. 
Nome: LIMA, Andrei Fernando Ferreira

Título: Édouard Glissant e a questão identitária antilhana

Dissertação de mestrado apresentada ao Departamento de Letras Modernas da Faculdade de Filosofia, Letras e Ciências Humanas da Universidade de São Paulo para obtenção do título de Mestre em Letras. Área de concentração: Estudos Linguísticos, Literários e Tradutológicos em Francês.

Aprovado em:

Banca Examinadora

Prof. Dr. Instituição:

Julgamento: Assinatura:

Prof. Dr. Instituição:

Julgamento: Assinatura:

Prof. Dr. Instituição:

Julgamento: Assinatura: 
À memória de meu avô Paulo Ferreira dedico este texto. 


\section{AGRADECIMENTOS}

Gostaria de agradecer principalmente à Prof. ${ }^{a}$ Dr. ${ }^{a}$ Véronique Marie Braun Dahlet pelo apoio que me testemunhou ao longo desta pesquisa. Desde as primeiras reflexões sobre o tema até a redação final, seu vasto conhecimento científico e sua rigorosa atenção constituíram para mim uma luz e um permanente estímulo. Que ela possa encontrar nestas breves palavras a certeza de meu respeito e a expressão sincera de meu reconhecimento.

Registro meus agradecimentos também aos membros da Mesa Examinadora pela leitura e apreciação deste trabalho: Prof. ${ }^{a}$ Dr. ${ }^{a}$ Claudia Consuelo Amigo Pino (Universidade de São Paulo), Prof. ${ }^{a}$ Dr. ${ }^{a}$ Eurídice Figueiredo (Universidade Federal Fluminense) e Prof. ${ }^{a}$ Dr. ${ }^{a}$ Luciane Alves Santos (Universidade Federal da Paraíba).

Estendo tais considerações ainda aos docentes da área de Francês do curso de Letras pelo papel fundamental que tiveram em minha formação, pelo convívio e proximidade dos quais pude tão proveitosamente privar.

Minha cordial lembrança, enfim, àqueles que me deram sua palavra de encorajamento e amizade. 
Porque a memória histórica foi tão frequentemente rasurada, o escritor antilhano deve "escavar" esta memória, a partir de traços por vezes latentes que ele localizou no real.

Porque a consciência antilhana foi balizada por barreiras esterilizantes, o escritor deve poder exprimir todas as ocasiões em que estas barreiras foram parcialmente rompidas.

Porque o tempo antilhano foi estabilizado no nada de uma não-história imposta, o escritor deve contribuir para restabelecer sua cronologia atormentada, isto é, para desvelar a vivacidade fecunda de uma dialética refeita entre natureza e cultura antilhanas.

Édouard Glissant, Le Discours antillais (1981). 


\section{RESUMO}

LIMA, Andrei F. F. Édouard Glissant e a questão identitária antilhana. 2017. 109 f. Dissertação (Mestrado) - Faculdade de Filosofia, Letras e Ciências Humanas da Universidade de São Paulo. Departamento de Letras Modernas. Área de concentração: Estudos Linguísticos, Literários e Tradutológicos em Francês. São Paulo, 2017.

Este estudo procura discutir a presença e as implicações da questão identitária antilhana na obra Le Discours antillais (1981), de Édouard Glissant. Levando em conta o contexto histórico de formação da sociedade antilhana, sua especificidade cultural e o peso da pesquisa de identidade na região, serão avaliados o modo de apresentação dessa problemática no texto glissantiano, suas articulações internas, as possibilidades de diálogo com outras fontes, sua associação ao projeto literário do autor e o papel que desempenha na configuração de sua poética. Escritor de muitas facetas, Glissant é tanto reconhecido por sua ação política frente à assimilação cultural e à departamentalização de sua ilha natal, a Martinica, pela França, quanto pela vasta produção que desenvolveu, a qual reúne gêneros e matérias diversas. $O$ fio condutor de seu trabalho, porém, é inegavelmente a questão identitária antilhana, responsável por seu empenho em afirmar-se como autor independente e em afirmar um campo literário antilhano autônomo, a partir do que contribuiu de maneira significativa para a reflexão acerca dos quadros póscoloniais, das relações interculturais na contemporaneidade e da formação de novas identidades. Em Glissant, as Antilhas são o paradigma de um movimento que hoje abrange todo o mundo, a "crioulização", que consiste na hibridização e nas trocas de elementos culturais, étnicos e linguísticos entre as coletividades, com resultados imponderáveis e surpreendentes. No exame da questão identitária antilhana, o autor desconstrói categorias fixas do pensamento ocidental, propondo novos conceitos, mais flexíveis e dinâmicos como a Relação e o Diverso, que definem a possibilidade de a noção de identidade ser pensada para além de uma origem única, projetando formas originais de identificação. Assim concebida, a análise ora apresentada mostrará a maneira particular segundo a qual o escritor interpreta a busca de identidade nas Antilhas e o lugar central ocupado por Le Discours antillais na organização desse tema, além do alcance das considerações do autor para o entendimento das complexas tramas culturais que irrompem na atualidade. Espera-se, enfim, por meio desta leitura, concorrer em qualquer sorte para o enriquecimento da fortuna crítica sobre tão importante pensador contemporâneo.

Palavras-chave: Identidade. Cultura. Língua. Antilhas. Édouard Glissant. 


\begin{abstract}
LIMA, Andrei F. F. Édouard Glissant and the Antillean identity matter. 2017. 109 f. Dissertação (Mestrado) - Faculdade de Filosofia, Letras e Ciências Humanas da Universidade de São Paulo. Departamento de Letras Modernas. Área de concentração: Estudos Linguísticos, Literários e Tradutológicos em Francês. São Paulo, 2017.

This study aims to discuss the presence and the implications of the Antillean identity matter on the work Le Discours antillais (1981), by Édouard Glissant. Considering the historical context in which the Antillean society was built, its cultural specificities and the importance of identity research in this region, we will evaluate the way this issue is presented on Glissant's text, its internal articulations, the possibilities of interactions with other sources, its association with the author's literary project and the role it plays in the setting of his poetics. A writer of many facets, Glissant is recognized both for his political action against the cultural assimilation and the departmentalization of his home island, Martinique, by France, and for his vast production, which includes various genres and subject matters. Although, the common thread of his work is undeniably the Antillean identity issue, that is responsible for his efforts to assert himself as an independent author and to reinforce the existence of an autonomous Antillean literary field, from what he significantly contributed to the reflections about postcolonial frameworks, intercultural relations in the contemporary world and the development of new identities. For Glissant, the Antilles are the paradigm of a movement that nowadays embraces the whole world, the "creolization", which consists in hybridity and in the exchanges of cultural, ethnic and linguistic elements between the communities, leading to imponderable and surprising results. When examining the Antillean identity matter, the author deconstructs fixed categories of the western thought, proposing new, more flexible and dynamic concepts, such as Relation and Diversity, which define the possibility of an identity notion that goes beyond a unique origin, projecting original forms of identification. Being conceived in this way, this analysis will show the particular manner in which the writer interprets the search for identity in the Antilles and the central role Le Discours antillais plays on the organization of this matter, as well as the outreach of the author's considerations for the understanding of the complex cultural plots that erupt in the present days. Finally, it is hoped that this research will possibly contribute to enriching the critical fortune of such a relevant contemporary thinker.
\end{abstract}

Key words: Identity. Culture. Language. Antilles. Édouard Glissant. 


\section{RÉSUMÉ}

LIMA, Andrei F. F. Édouard Glissant et la question identitaire antillaise. 2017. 109 f. Dissertação (Mestrado) - Faculdade de Filosofia, Letras e Ciências Humanas da Universidade de São Paulo. Departamento de Letras Modernas. Área de concentração: Estudos Linguísticos, Literários e Tradutológicos em Francês. São Paulo, 2017.

Cette étude cherche à discuter la question identitaire antillaise et ses implications dans l'œuvre Le Discours antillais (1981), d'Édouard Glissant. En tenant compte du contexte historique de la formation de la société antillaise, de sa spécificité culturelle et du poids de la quête d'identité dans la région, seront évalués le mode de présentation de cette problématique dans le texte glissantien, ses articulations internes, les possibilités de dialogue avec d'autres sources, son statut par rapport au projet littéraire de l'auteur et le rôle que joue cette problématique dans la configuration de sa poétique. Écrivain à plusieurs facettes, Glissant est autant reconnu par son action politique face à l'assimilation et à la départementalisation par la France de son île natale, la Martinique, que par la vaste production qu'il a développée, laquelle réunit différents genres et divers thèmes. Le fil conducteur de son travail, en tout cas, c'est indéniablement la question identitaire antillaise, qui a provoqué son engagement en tant qu'auteur indépendant et a produit un champ littéraire antillais autonome, à partir de quoi il a contribué de manière significative à la réflexion concernant les cadres post-coloniaux, des relations interculturelles contemporaines et la formation de nouvelles identités. Chez Glissant, les Antilles sont le paradigme d'un mouvement qui aujourd'hui couvre le monde entier: la créolisation. Celle-ci consiste dans l'hibridisation et dans l'échange d'éléments culturels, ethniques et linguistiques entre les collectivités, avec des résultats impondérables et suprenants. Dans l'examen de la question identitaire antillaise, l'auteur déconstruit des catégories fixes de la pensée occidentale, en proposant de nouveaux concepts, plus flexibles et dynamiques comme la Relation et le Divers, qui permettent de penser l'identité au-delà d'une origine unique, en projetant des formes originelles d'identification. Ainsi conçue, l'analyse présentée cherchera à montrer la manière particulière selon laquelle l'écrivain interprète la recherche d'identité aux Antilles et la place centrale occupée par Le Discours antillais dans l'organisation de ce thème, ainsi que la perception des trames culturelles complexes qui apparaissent dans l'actualité. Ainsi, à travers la lecture du Discours antillais, on espère concourir en quelque sorte à l'enrichissement de la fortune critique concernant un penseur contemporain si important.

Mots-clés: Identité. Culture. Langue. Antilles. Édouard Glissant. 


\section{Sumário}

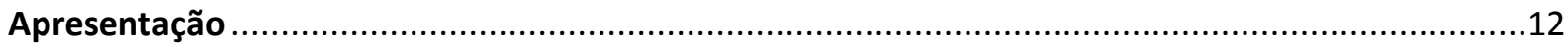

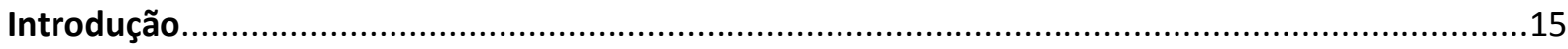

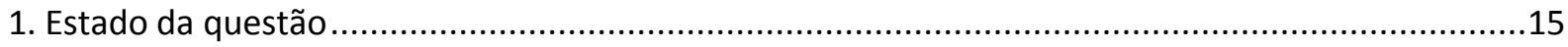

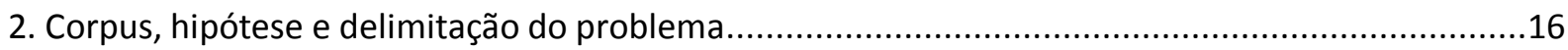

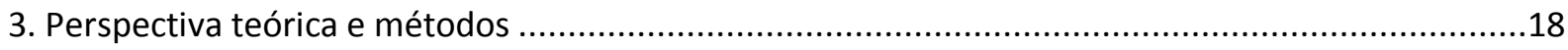

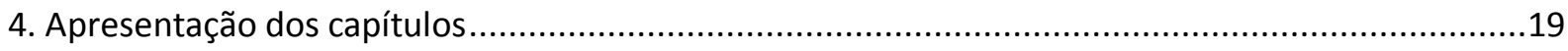

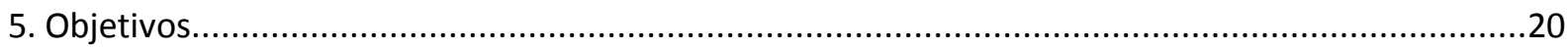

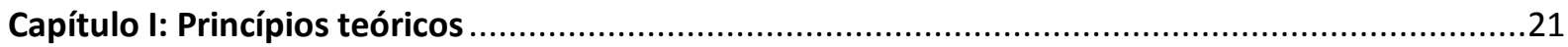

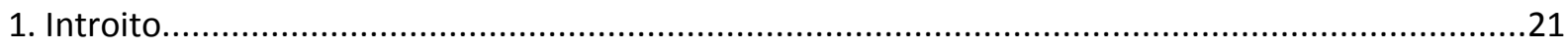

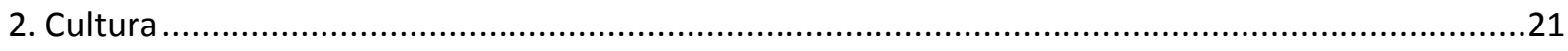

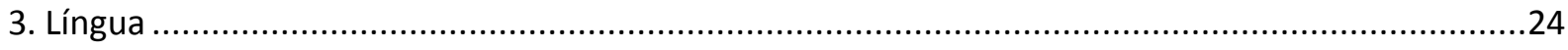

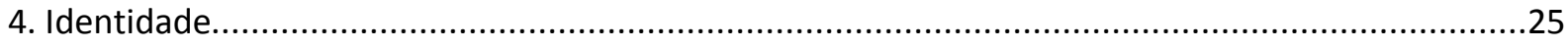

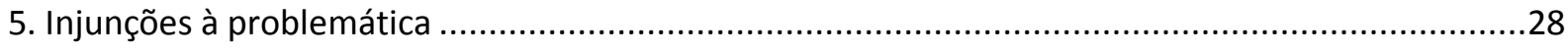

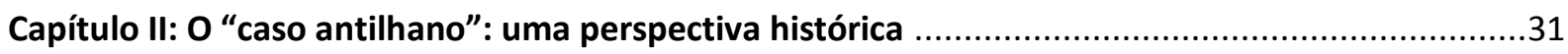

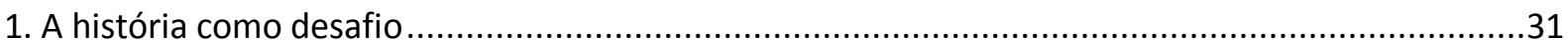

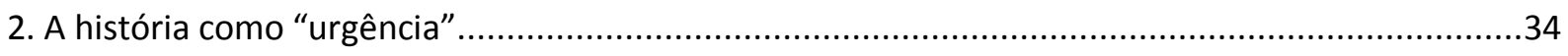

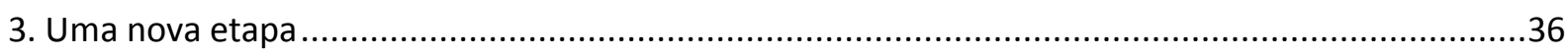

Capítulo III: Duas frentes de abordagem da questão identitária antilhana ....................................38

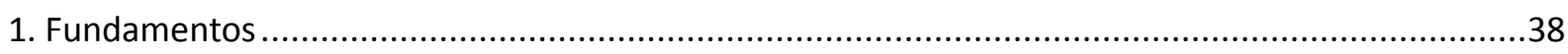

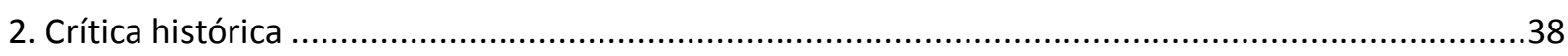

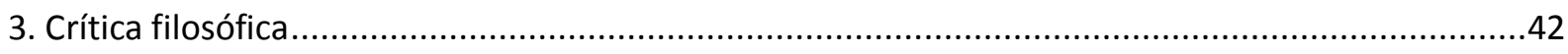

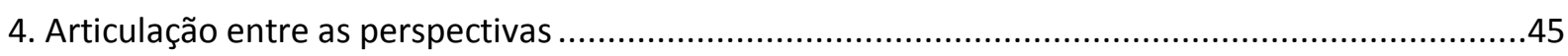

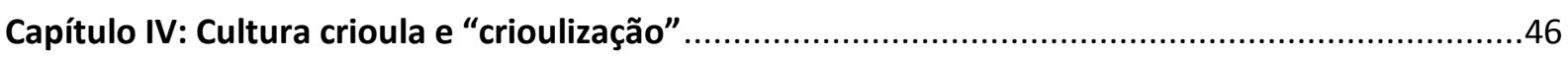

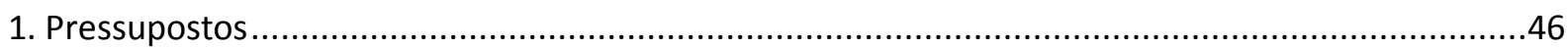

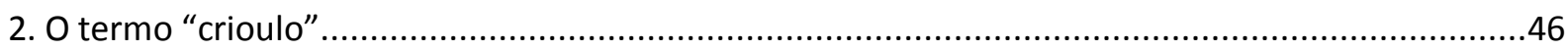

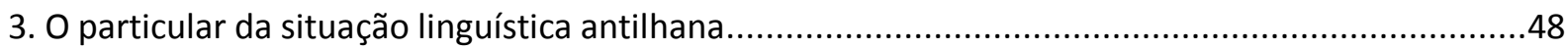

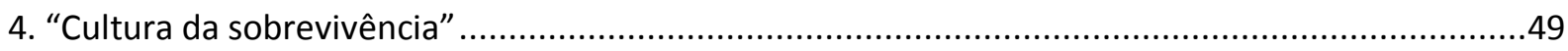

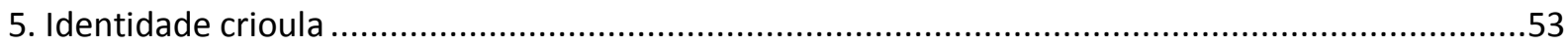

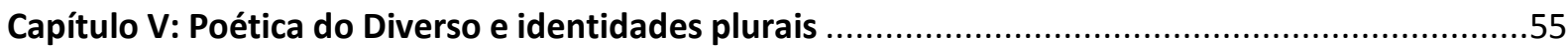

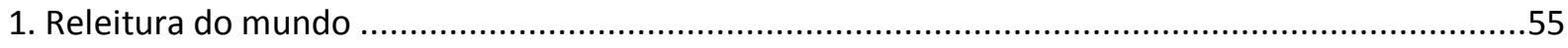

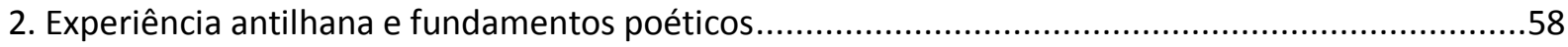

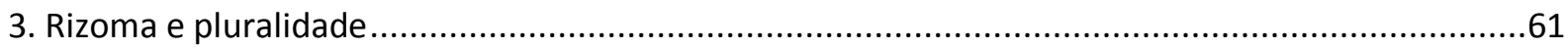

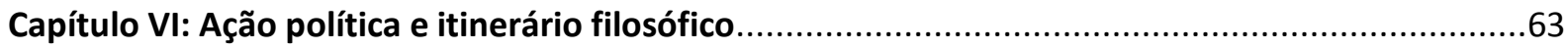

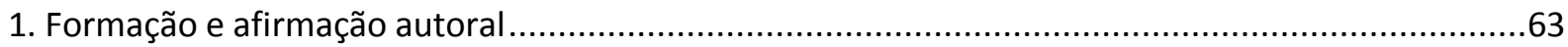




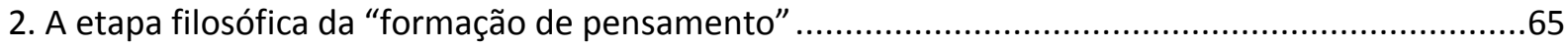

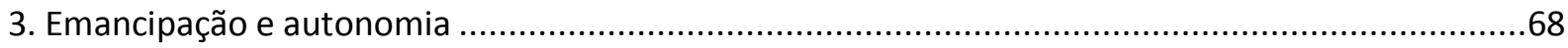

Capítulo VII: O programa identitário em Le Discours antillais .......................................................70

1. Uma intensa relação entre forma e conteúdo ..........................................................................70

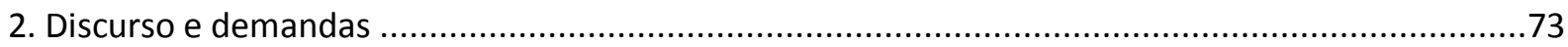

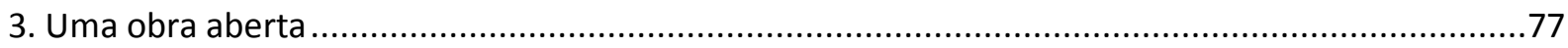

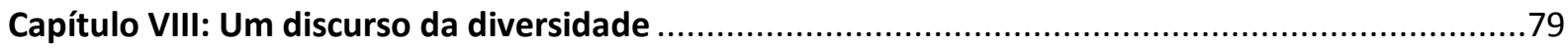

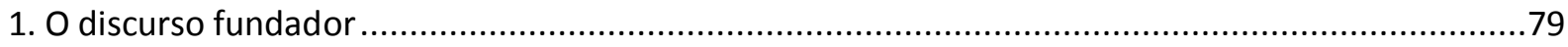

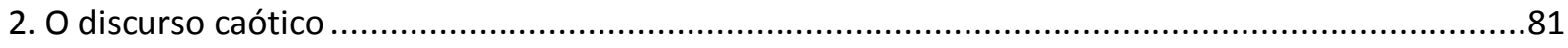

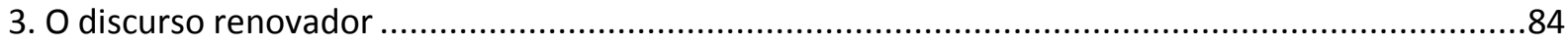

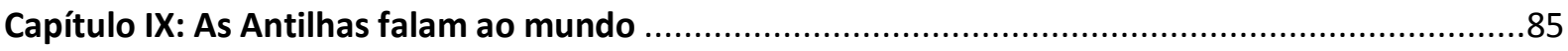

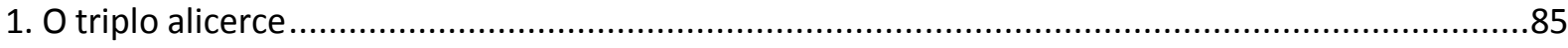

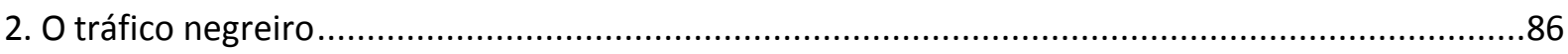

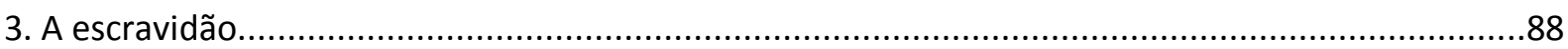

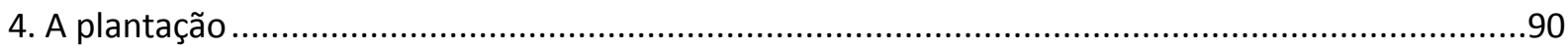

5. Para além da experiência insular, o imaginário das culturas ....................................................91

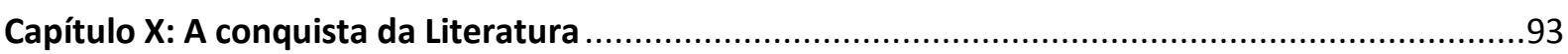

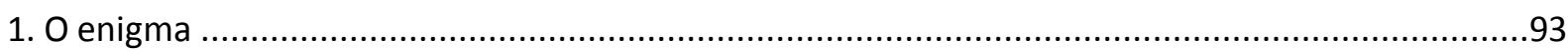

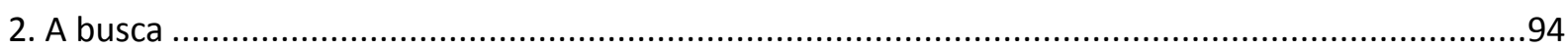

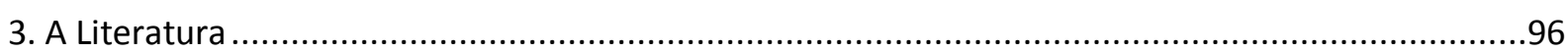

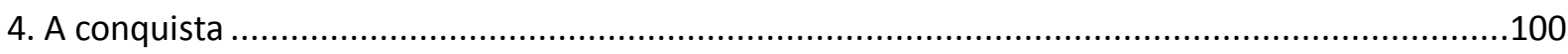

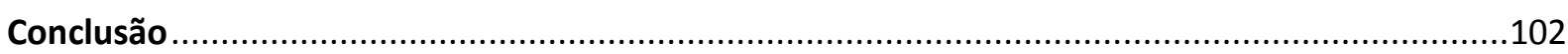

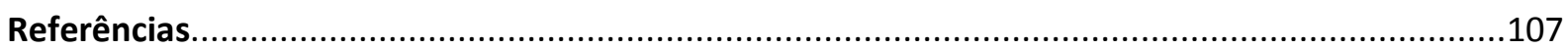




\section{Apresentação}

Autor polígrafo, Édouard Glissant trilhou um percurso de inovações e contribuições para a história do pensamento e a literatura, deixando marcas duradouras em seu tempo ao criar uma obra particularmente vasta. Sua importância pode ser sentida em diferentes gêneros literários e campos do saber, pois como ficcionista publicou romances, contos, peças teatrais e poesias, e como teórico desenvolveu estudos filosóficos, históricos e antropológicos, além de ter introduzido na crítica literária conceitos tais como a Relação, o Diverso e o Todo-mundo ${ }^{1}$. Politicamente engajado, Glissant articulou diversos movimentos liberais nas Antilhas ${ }^{2}$ e no exterior favoráveis à emancipação dos Departamentos franceses de ultramar ${ }^{3}$. Por meio de intensas iniciativas, defendeu a abertura do diálogo intercultural entre os povos, conforme uma série de trabalhos surgidos nos anos 1990 tendo por núcleo as noções que o escritor nomeia "crioulização" e "mundialidade": Poétique de la Relation (1990), Introdução a uma poética da diversidade $(1995)^{4}$ e Traité du Tout-monde (1997). Atuou ainda junto à Unesco e manteve uma dinâmica vida acadêmica como docente na Louisiana State University e na City University of New York, onde dedicou-se ao ensino de literatura francesa. Com esta rica trajetória, Glissant figura ao lado de seu conterrâneo Frantz Fanon e do jamaicano Stuart Hall como um dos mais reconhecidos e influentes escritores do Caribe.

Nascido em 1928 em Bezaudin, localidade rural da Comuna de Sainte-Marie, Martinica, filho de uma dona de casa e de um administrador das plantações canavieiras, Glissant cedo deixou sua cidade natal para seguir com a família ao centro de Lamentin, que oferecia então maiores recursos e oportunidades por se tratar de importante polo econômico na ilha. Neste endereço realizou seus primeiros estudos e, em 1938, conseguiu uma bolsa que lhe permitiu ingressar no prestigiado Liceu Schœlcher de Fort-de-France. Entre 1940 e 1945, em plena Segunda Guerra Mundial, passou por grandes dificuldades, inclusive para assegurar a

\footnotetext{
${ }^{1}$ Conceitos fundamentais da poética de Glissant ligados à proposta de integração ao diálogo intercultural e a um novo modo de leitura das relações humanas na modernidade. Ao longo deste trabalho, tais noções serão retomadas e devidamente esmiuçadas.

${ }^{2}$ Região insular da América Central banhada pelo mar do Caribe que compreende diversos países com línguas e processos de formação étnico-cultural essencialmente distintos, os quais se dividem, a rigor, em duas escalas: as Pequenas Antilhas (Martinica, Aruba, Curaçau, etc.) e as Grandes Antilhas (Jamaica, Haiti, Cuba, etc.). Devido ainda ao passado colonial e às atuais relações político-administrativas entre muitos países da região e a Europa, costuma-se falar em Antilhas francesas, britânicas, holandesas...

${ }^{3}$ Divisão administrativa do território francês. Neste caso, o termo refere-se especificamente aos territórios de ultramar sujeitos ao governo francês.

4 Trad. Enilce Albergaria Rocha. Juiz de Fora: Editora UFJF, 2005.
} 
própria subsistência, mas descobriu igualmente a política e as letras, participando de movimentos juvenis contestatórios e publicando seus primeiros versos.

Decisivo para sua carreira foi o período compreendido entre 1951 e 1956, quando, já estabelecido em Paris há alguns anos, inscreveu-se no curso de filosofia da Sorbonne e obteve o diploma superior com o memorial "Découverte et conception du monde dans la poésie contemporaine", sob coordenação de Jean Wahl, que apresentou em 1953. Paralelamente, vieram à luz seus livros de poesia Un champ d'îles (1953), La Terre inquiète (1955) e Les Indes (1956), além de seu ensaio de estreia, Soleil de la conscience (1956). Nos anos seguintes, continuou uma intensa atividade intelectual, escrevendo críticas, apresentações de exposições artísticas e diversos artigos, a maioria dos quais para a revista Lettres Nouvelles, posteriormente retomados em L'Intention poétique (1969). Antes, porém, lançou o romance La Lézarde (1958), que lhe trouxe o prêmio Renaudot e enorme publicidade.

Os anos 1960 foram talvez os mais atribulados da vida do autor, porque envolveu-se ativamente nos movimentos independentistas do Norte da África, especificamente na causa argelina, e do Caribe. Entre participações em frentes de combate político e denúncia e indisposições com o governo francês, publicou aquela que seria sua única peça teatral, Monsieur Toussaint (1961), sobre o revolucionário haitiano do século XIX e símbolo da luta libertária antilhana. Em 1965 apareceu seu segundo romance, O Quarto Século ${ }^{5}$, pelo qual recebeu o prêmio Charles Veillon, e em 1975, Malemort.

Em 1981 lançou La Case du commandeur e seu mais complexo trabalho sobre a realidade antilhana, Le Discours antillais, resultado de uma pesquisa sustentada junto à Universidade de Paris I. Seguiram-se a essas publicações, Pays rêvé, pays réel (1985) e Mahagony (1987), Tout-monde (1993), Faulkner, Mississipi (1996) e Sartorius, le roman des Batoutos (1999). O autor participou ainda intensamente de palestras, congressos, colóquios e vários outros eventos na Europa, Estados Unidos e América do Sul, a exemplo da conferência realizada no Rio de Janeiro na Universidade Federal Fluminense em 1982: "O escritor diante de sua obra: criação e reflexão".

Nos anos 2000 sua produtividade continuou, com destaque para as obras Le Monde incréé (2000), Ormerod (2003), La Cohée du Lamentin (2005) e Philosophie de la Relation

\footnotetext{
${ }^{5}$ Trad. Cleone Augusto Rodrigues. Rio de Janeiro: Editora Guanabara, 1986.
} 
(2009), além de inúmeras entrevistas que concedeu a diferentes periódicos e revistas, divulgando seu pensamento e seus conceitos e opinando sobre temas contemporâneos.

Distinguido por uma particular delicadeza e generosidade, Glissant desfrutou do reconhecimento de seus pares e de um público cada vez mais amplo e interessado, sempre disposto a compartilhar a visão poética e criativa que nutria acerca da humanidade. Assim, laureado e consagrado, mas principalmente estimado em alto grau, o renovador da literatura antilhana faleceu em Paris em fevereiro de 2011, aos 82 anos.

Suas ideias e obras, atualíssimas, permanecem alimentando reflexões e estudos diversos, como fontes perenes de novas descobertas e possibilidades de interpretação, como marcos na história do pensamento, sempre instigantes e desafiadoras em seu fulgor. 


\section{Introdução}

\section{Estado da questão}

Especialmente rica quanto à reflexão acerca das relações políticas, sociais, linguísticas e identitárias no contexto antilhano, a obra de Glissant tem movimentado um significativo contingente de trabalhos científicos que operam nesta chave ${ }^{6}$. Poucas pesquisas, porém, centram-se com minudência naquele que é tido como núcleo gerador de todo o pensamento amadurecido do autor ${ }^{7}$, o seminal Le Discours antillais. Neste livro de grande fôlego podem ser encontradas, com efeito, as microestruturas de inúmeros conceitos que organizam a poética glissantiana e que posteriormente foram resgatados e ampliados em definições epistemológicas precisas.

Também é Le Discours antillais a expressão maior de um "projeto identitário" antilhano, isto é, do esforço pela redescoberta da cultura nacional do povo caribenho, o que se revela em sua organicidade, uma vez que a obra analisa detidamente eventos, experiências, aspectos humanos, culturais, da paisagem e da história local, como se fora um registro, um documento ou dossiê que testemunha a antilhanidade ${ }^{8}$. E a própria expressão da palavra, quando se pensa no sentido de um discurso antilhano, deixa ver a enorme força intelectual que detém: trata-se de um discurso inaugural que pretende dar àquela comunidade voz simbólica, conferindo-lhe assim uma identidade.

Por tudo isso, entendeu-se serem necessários um exame mais detido sobre tão importante obra do repertório glissantiano e uma avaliação crítica em que Le Discours antillais fosse de fato protagonista, conforme seu peso e relevância ademais exigem. Semelhante disposição foi reforçada também pelo levantamento do estado da questão identitária antilhana a partir deste livro especificamente, o que resultou na surpreendente constatação de que é exíguo o cabedal teórico existente, conforme referido acima. Para tanto, basta considerar que, desde

\footnotetext{
6 "Se destaca da obra literária de Glissant uma consciência aguda, senão uma preocupação obsedante, da significação da História percebida e vivida pelo povo antilhano. Eis uma constatação bastante evidente quando consideramos o número de estudos críticos tratando desta dimensão temática em Glissant" (CROSTA, 1991, p. 21). Todas as traduções neste texto, salvo quando indicado, são nossas.

${ }^{7}$ Isso devido à decantada experiência intelectual do autor, a qual se processa a partir da publicação dos ensaios Soleil de la conscience e L'Intention poétique, onde descreve os fundamentos de uma proposta "poética" ainda insipiente. É de fato com Le Discours antillais que nasce o programa literário-filosófico glissantiano.

${ }^{8}$ Caráter ou qualidade peculiar que particulariza quem é antilhano. O conceito de antilhanidade, enquanto proposta de afirmação da identidade cultural antilhana, precede o conceito de "crioulização" no pensamento de Glissant.
} 
seu aparecimento em 1981, não há estudos integralmente consagrados a Le Discours antillais nem trabalhos de referência que tomem este livro como objeto de pesquisa aprofundada.

No Brasil, vale lembrar, o estudo pioneiro sobre o autor martiniquense foi publicado por Diva Damato, Édouard Glissant: Poética e Política (1996), resultado de sua tese de doutoramento sustentada em 1987, a qual teve como fator decisivo, segundo a própria autora, a publicação de Le Discours antillais. Seguiu-se, então, a contribuição de Enilce Albergaria Rocha, também fruto de um doutorado, “A Utopia do Diverso: O pensamento Glissantino nas Escritas de Édouard Glissant e Mia Couto”, de 2001. Todavia não são estes trabalhos centrados integralmente em Le Discours antillais e não discutem ali a questão de identidade propriamente.

Visando o enriquecimento do arcabouço crítico sobre o tema identitário em Le Discours antillais e o oferecimento de um olhar original sobre a presença e as implicações dessa questão no pensamento de Édouard Glissant, o presente trabalho vem tomar posição enunciativa ao lado dos estudos culturais e pós-coloniais, assumindo a dinâmica das formações culturais em contextos diaspóricos e o alcance da pesquisa de identidade entre os povos colonizados no Ocidente. De forma ainda mais sensível nas Antilhas, tal questão requer um exame atento dos processos históricos, sociais e políticos que levaram à constituição daquela comunidade e aos dilemas (linguísticos, identitários, etc.) trazidos em seu bojo, conforme será definido nas etapas que compõem o exame ora proposto.

Enfim, esta pesquisa coloca-se, pelo objeto escolhido e pelo enfoque adotado, num lugar intelectual sujeito à experimentação e à inovação criativa, sem deixar, no entanto, de manter sempre a rigorosa observação do referencial de conhecimento já consolidado e da coerência frente aos conceitos adotados.

\section{Corpus, hipótese e delimitação do problema}

Esta pesquisa dedica-se, portanto, a explorar o percurso reflexivo de Édouard Glissant em Le Discours antillais a propósito da questão linguística e identitária nas Antilhas, tendo em vista a importância crucial deste debate em semelhante contexto histórico e sócio-político, além evidentemente de suas implicações na literatura e no pensamento antilhanos.

Embora não exaustivo, o corpus de análise não deixa de representar com rigor o modo como esta questão se apresenta para o autor, pois, ainda que o tópico permeie sua produção, é em Le Discours antillais que de fato surge pela primeira vez como objeto de uma discussão 
bem articulada e aprofundada, gerando mais tarde, segundo referido, o manancial crítico de Glissant.

Quais aspectos caracterizam esta aparição inicial do problema? Como o autor percebe a questão e a interpreta? Qual é a proposta que defende e quais recursos mobiliza para sustentála? Procedendo a um exame detido da obra, pretende-se responder a estes questionamentos fundamentais, e mais, investigar e compreender os contornos que a problemática relação entre identidade linguística e cultural nas Antilhas assume na produção do autor.

Sabe-se que as identidades culturais repousam em noções abstratas como língua, religião, pátria, etc., as quais foram profundamente deslocadas no contexto da modernidade e de forma mais aguda ainda entre as ex-colônias europeias, o que levou diversos autores a refletirem sobre a questão identitária em semelhante contexto, a exemplo de Frantz Fanon, Edward Said e Homi Bhabha.

O que está em jogo para estes autores é o fenômeno social da "crise das identidades" em um mundo em transformação, marcado por novas ordens políticas e por novas perspectivas nas relações humanas, onde a "emergência de identidades plurais" (RIVAS, 2005, p. 236) veio assinalar a necessidade de se rever o conceito, até então observado em termos de unidade e particularidade.

Como observa o estudioso Kobena Mercer (1990 apud HALL, 2006, p. 09), “a identidade somente se torna uma questão quando está em crise, quando algo que se supõe como fixo, coerente e estável é deslocado pela experiência da dúvida e da incerteza”, ou seja, quando são abalados os quadros de referência que dão segurança ao indivíduo no mundo social a noção mesma de identidade é posta em jogo e relativizada.

A busca da identidade antilhana em Édouard Glissant é, ao mesmo tempo, um problema a ser resolvido e um projeto de pensamento. Para o escritor não basta apenas instituir uma identidade linguística e cultural que caracterize a acalentada ideia de uma antilhanidade essencial, mas cumpre também propor um novo olhar sobre as identidades no cenário globalizado contemporâneo, cuja leitura pressupõe a percepção da diversidade como um fato.

O problema específico que se propõe discutir aqui liga-se, assim, ao próprio debate das noções de língua, cultura e identidade, e à sua relação na obra do autor. Como inspiração à abordagem deste tema, o estudo de Pierre Rivas (2005, p. 236) traz as exatas linhas de força da problemática ora instaurada: “a relação do escritor dependente com a língua materna e com a 
língua do antigo colonizador; mais ainda, relação entre literatura, língua e nação; mais precisamente, relação entre o escritor da modernidade e a nação na era da pós-modernidade”.

\section{Perspectiva teórica e métodos}

Investigar a questão implica considerar heranças históricas, entrecruzamentos de culturas e tradições, dinâmicas linguísticas, dilemas sociopolíticos e discursos à luz da interdisciplinaridade. Nesta pesquisa, por isso, terão destaque as correntes de estudos póscoloniais e de estudos culturais, a sociologia, a história, a linguística e a teoria literária, que apoiarão as discussões, reflexões e conclusões provisórias aqui desenvolvidas ${ }^{9}$.

Pela ordem descrita, serão distinguidas as teorias de Albert Memmi (1967), Homi Bhabha (1998) e Frantz Fanon (2008), autores que exerceram a crítica do colonialismo; de Stuart Hall (2006) e (2008), cujo trabalho inaugurou uma nova página do pensamento contemporâneo, os cultural studies, com importantes contribuições para as políticas identitárias e para o debate cultural na modernidade; de Denys Cuche (1999), Jacki Dahomay (2000) e Terry Eagleton (2005), de lembrança fundamental sobre a evolução da noção de cultura e sua presença nas ciências sociais; de Paul Ricœur (2007), sobre relações de poder e discursos de dominação em vias históricas; de Bakhtin (1997) e Kramsch (1998), fontes essenciais para a integração sociolinguística e para a leitura comparada dos conceitos de língua e cultura; e por fim ganham ênfase os textos críticos sobre Glissant, especialmente aqueles de Daniel Radford (1982), Suzanne Crosta (1991), Diva Damato (1996), Jean-Pol Madou (1996), Dominique Chancé (2001) e Romuald-Blaise Fonkoua (2002), todos estes responsáveis por análises profundas e rigorosas da obra glissantiana, oferecendo pontos de vista diversificados sobre diferentes temas e noções ali presentes.

À luz dessas interpretações variadas e com base também nas obras de outros nomes que compõem o universo artístico e intelectual antilhano ${ }^{10}$, além do constante diálogo com os

\footnotetext{
${ }^{9}$ A esse propósito, gostaríamos de fazer nossas as palavras de Stuart Hall (2006, pp. 08-09): “A opinião dentro da comunidade sociológica está profundamente dividida quanto a esses assuntos. As tendências são demasiadamente recentes e ambíguas. O próprio conceito com o qual estamos lidando, "identidade", é demasiadamente complexo, muito pouco desenvolvido e muito pouco compreendido na ciência social contemporânea para ser definitivamente posto à prova. Como ocorre com muitos fenômenos sociais, é impossível oferecer afirmações conclusivas ou fazer julgamentos seguros sobre alegações e proposições teóricas que estão sendo apresentadas. Deve-se ter isso em mente ao se ler o restante do livro".

${ }^{10}$ A exemplo de Aimé Césaire, Frantz Fanon, Jean Bernabé, Patrick Chamoiseau, Rafaël Confiant, Gisèle Pineau, etc.
} 
demais trabalhos do próprio Glissant ${ }^{11}$, pretende-se dispor de uma nova dimensão na análise da presença da questão identitária em Le Discours antillais, cuja interrogação parece ser crucial para melhor compreender a proposta de um projeto de afirmação da identidade antilhana pelo escritor, para distinguir suas principais características, para identificar seu valor no âmbito da poética glissantiana e o modo como esta questão se articula à emergência de uma nova concepção de identidade.

\section{Apresentação dos capítulos}

O capítulo inicial é consagrado à apresentação dos princípios teóricos que orientam a pesquisa, ou seja, as noções de cultura, língua e identidade, as quais se espera poder avaliar em termos de evolução histórica e recepção teórica. No capítulo II, são discutidos aspectos referentes à formação histórica da sociedade antilhana, de modo a demonstrar as raízes do problema específico que se busca analisar nesse contexto. No capítulo III, são introduzidas e aprofundadas duas perspectivas epistemológicas que orientam a discussão acerca da questão identitária em Glissant, aqui nomeadas crítica histórica e crítica filosófica. O capítulo IV oferece um panorama da especificidade cultural antilhana, esclarecendo a origem do termo "crioulo" e sua presença no âmbito linguístico, além de dispor sobre a noção de "crioulização" como processo. No capítulo $\mathrm{V}$, discute-se o conceito do Diverso na poética glissantiana e em que medida este conceito está associado à leitura das chamadas "identidades plurais". O capítulo VI versa sobre a ação política de Glissant e suas implicações para o desenvolvimento do itinerário filosófico do autor. A partir do capítulo VII, são tratados os termos em que se apresenta a pesquisa de identidade em Le Discours antillais, com atenção ao programa de investigação da questão identitária segundo as perspectivas histórica, social, linguística e cultural. Assim, no capítulo seguinte, trata-se da ideia de um "discurso da diversidade" como parte da proposta glissantiana de interpretação e penetração da realidade antilhana, onde o discurso representa simbolicamente a voz daquela cultura. Já no capítulo IX procura-se mostrar que o pensamento de Glissant, configurado a partir de sua experiência cultural insular, desborda os limites do Caribe, alcançando o mundo, porquanto contribui para o entendimento dos encontros entre culturas, línguas e identidades que tão fortemente caracterizam a contemporaneidade. O capítulo final, por sua vez, vem apresentar o papel da literatura no

\footnotetext{
${ }^{11}$ Em virtude do claro caráter autoexegético da obra de Glissant, isto é, pela possibilidade de seus textos serem lidos e interpretados à luz dos próprios conceitos que elaborou e que constituem sua "Poética".
} 
contexto da pesquisa de identidade nas Antilhas e como o projeto literário glissantiano contribuiu para a afirmação dessa identidade. De modo que se pretende, no oferecimento destes muitos pontos de vista que se articulam e complementam, chegar a um efeito consistente e objetivo acerca da análise do tema proposto.

\section{Objetivos}

Constitui o principal objetivo desta pesquisa o desenvolvimento de um discurso crítico sobre a presença da questão identitária antilhana em Le Discours antillais, sobre as relações culturais no contexto caribenho, sobre as particularidades linguísticas, sociais e históricas ali observadas, admitindo-se que neste livro Glissant empreende a tentativa mais contundente de abarcar o real antilhano. Na reflexão ora instaurada, buscar-se-á oferecer uma perspectiva da poética glissantiana e dos conceitos que a organizam, bem como revelar o projeto literário do autor martiniquense, através do qual esforça-se por responder àquelas perguntas sempiternas:

Com efeito, o que pode ser a literatura de um povo arrancado de sua origem há quatro
séculos pelo tráfico e que, na ausência de uma memória coletiva, jamais pôde elaborar
por meio de mitos e epopeias, a categoria do passado? O que é um povo nascido
brutalmente na modernidade e que não pôde amadurecer nas profundezas
estratificadas do tempo? (MADOU, 1996, p. 07 , grifo do autor).

A leitura apresentada procura revelar os caminhos da pesquisa identirária em Le Discours antillais, o modo como esta questão se traduz no pensamento glissantiano e as disposições que assume no surgimento de um modelo poético relacional, onde o eu cede espaço ao nós, onde o Um integra-se ao Diverso, onde a História pluraliza-se em histórias, o qual projeta uma nova visão dos contatos entre povos e culturas no mundo.

Espera-se, enfim, por meio deste estudo, contribuir com as pesquisas gerais sobre Glissant, já bastante amplas na Europa e nos Estados Unidos, franqueando o acesso à obra e aos desafios do pensamento deste importante autor contemporâneo. Sem qualquer julgamento definitivo acerca dos voláteis conceitos aqui discutidos, propõe-se basicamente uma reflexão em torno das noções de cultura, língua e identidade, mostrando como a problemática identitária antilhana se configura para Édouard Glissant e quais contornos assume em seu trabalho, o que sem dúvida deve inspirar uma "outra maneira de frequentar este mundo, uma atividade ardente do imaginário, uma transformação real do espírito e da sensibilidade [...]” (GLISSANT, 1993, p. 48). 


\section{Capítulo I: Princípios teóricos}

\section{Introito}

Inicialmente, e como forma de contextualizar a reflexão proposta neste estudo acerca da presença da questão identitária antilhana na obra de Édouard Glissant, serão retomadas no presente capítulo algumas das principais definições para os conceitos de cultura, língua e identidade, considerados princípios teóricos essenciais para o desenvolvimento da problemática aqui instaurada, o que permitirá acompanhar a evolução desta discussão ao longo da história moderna e assim avaliar suas implicações para a pesquisa desenvolvida.

\section{Cultura}

Podem ser encontrados diversos registros para a conceituação de cultura na tradição filosófico-literária ocidental. Conforme assinala Terry Eagleton (2005, p. 09), trata-se de "uma das duas ou três palavras mais complexas de nossa língua, e ao termo que é por vezes considerado seu oposto - 'natureza' - é comumente conferida a honra de ser o mais complexo de todos". Todavia - ainda recuperando o pensamento desse autor -, "embora esteja atualmente em moda considerar a natureza como um derivado da cultura, o conceito de cultura, etimologicamente falando, é um conceito derivado do de natureza" (EAGLETON, 2005, p. 09).

De fato, a origem primeira do vocábulo data da latinidade, quando pertencia, conforme assinala Cuche (1999, p. 19), ao léxico relativo às práticas agropastoris, designando "o cuidado dispensado ao campo ou ao gado" ou "parcela de terra cultivada". Em sua forma original, o verbo colere significava exatamente "cultivar" (EAGLETON, 2005, p. 10), mas ainda durante o período romano passou a expressar um sentido, por assim dizer, mais abstrato como polidez e civilidade no trato pessoal.

Durante a Idade Média este sentido ligado às lides da terra manteve-se. Na França, o mesmo pode ser identificado desde o século XIII até o início do século XVI, momento em que ocorre uma decisiva transformação. A partir das novas perspectivas oferecidas pelo Renascimento, movimento responsável pela redescoberta dos valores característicos do pensamento greco-latino, cultura passou a refletir uma instância vinculada ao espírito, isto é, ao intelecto, e ao aprimoramento de uma faculdade. 
Porém, dois séculos mais tarde, sob a influência do Iluminismo, a noção de cultura finalmente atingiu uma dimensão epistemológica próxima do sentido moderno do termo, consistindo na "soma dos saberes acumulados e transmitidos pela humanidade, considerada como totalidade, ao longo da sua história" (CUCHE, 1999, p. 21).

Assim, a ideia de cultura acompanhou a multiplicidade sugerida, no decorrer da história, pelo caráter polissêmico do vocábulo, transitando por diversas tendências e correntes de pensamento, combinando "de maneira estranha crescimento e cálculo, liberdade e necessidade, a ideia de um projeto consciente mas também de um excedente não planejável" (EAGLETON, 2005, p. 14). Nesse processo evolutivo, muitos conceitos e propostas surgiram, com maior ou menor êxito.

Transposta para o campo antropológico, a discussão em torno da noção de cultura ganhou novo relevo, pois esta passou a ser descrita segundo uma linha disciplinar específica, estabelecida por contraponto às definições formuladas pelas demais áreas do conhecimento como, por exemplo, história, sociologia ou psicanálise. Assim, conforme ressalta Terry Eagleton:

Se a palavra "cultura" guarda em si os resquícios de uma transição histórica de grande importância, ela também codifica várias questões filosóficas fundamentais. Neste único termo, entram indistintamente em foco questões de liberdade e determinismo, o fazer e o sofrer, mudança e identidade, o dado e o criado (EAGLETON, 2005, p. $11)$.

É no âmbito da tradição antropológica, mais especificamente, que nasce o conceito de "identidade cultural", o qual compreende um sistema de representação das relações entre os membros de um grupo social ou entre grupos sociais diferentes, que reflete a totalidade das características que lhe são peculiares e envolve o compartilhamento de propriedades comuns como a língua, as crenças, as artes, os costumes e as atividades ${ }^{12}$.

Em permanente construção, a identidade cultural de uma comunidade pressupõe um processo altamente complexo e dinâmico que opera no tempo e no espaço, cobrindo a diversidade das relações humanas e o conjunto de aspectos referentes à realidade social. Nas palavras de Santos (2006), a cultura, sob a perspectiva oferecida pela antropologia, seria

[...] uma construção histórica, seja como concepção, seja como dimensão do processo social. Ou seja, a cultura não é "algo natural", não é uma decorrência de leis físicas

\footnotetext{
${ }^{12}$ Stuart Hall (2006, p. 08) também fala em identidades culturais como "aqueles aspectos de nossas identidades que surgem de nosso 'pertencimento' a culturas étnicas, raciais, linguísticas, religiosas e, acima de tudo, nacionais".
} 
ou biológicas. Ao contrário, a cultura é um produto coletivo da vida humana (SANTOS, 2006, p. 45).

Ainda conforme esta visão, Santos (2006, pp. 23-24) apresenta duas concepções fundamentais de cultura, pensadas a partir de núcleos distintos - porém que se complementam. A primeira destas concepções refere-se à realidade social de um grupo organizado em comunidade ou nação, a tudo aquilo que envolve essa mesma realidade, sendo a forma moderna básica do conceito, cuja definição encontra-se intimamente ligada ao desenvolvimento das teorias sociais de viés científico durante o século XIX. Já a segunda delas, trata da totalidade de aspectos característicos de um grupo social, nela incluídos valores e ideias cujos significados podem ser observados nos hábitos, tradições, crenças, conhecimentos e instituições de um povo.

Também Ulmann (1991) assume a cultura em duas vias epistemológicas. O sentido primeiro, mais geral, corresponde ao modus vivendi criado pelos indivíduos que compõem uma sociedade, o qual é desenvolvido e transmitido ao longo do tempo. O sentido seguinte, mais particular, designa o modus vivendi próprio de uma determinada comunidade. Tomados estes dois pressupostos, o autor descreve a cultura como sendo "a superação daquilo que é dado pela natureza. Logo, é aquilo que o homem transforma" (ULMANN, 1991, p. 84).

Eagleton também explora a dialética cultura/natureza, numa linha de pensamento paralela àquela de Ulmann:

A cultura, assim, é uma questão de auto-superação tanto quanto de auto-realização. Se ela celebra o eu, ao mesmo tempo também o disciplina, estética e asceticamente. [...] Se somos seres culturais, também somos parte da natureza que trabalhamos. Com efeito, faz parte do que caracteriza a palavra "natureza" o lembrar-nos da continuidade entre nós mesmos e nosso ambiente, assim como a palavra "cultura" serve para realçar a diferença.

Nesse processo de automoldagem, unem-se mais uma vez ação e passividade, o ardorosamente desejado e o puramente dado - desta vez nos mesmos indivíduos. Nós nos assemelhamos à natureza, visto que, como ela, temos de ser moldados à força, mas diferimos dela uma vez que podemos fazer isso a nós mesmos, introduzindo assim no mundo um grau de auto-reflexividade a que o resto da natureza não pode aspirar (EAGLETON, 2005, p. 15).

Significa dizer que a cultura, concebida no âmbito da natureza - posto que os homens a ela estão integrados -, acaba por ultrapassar suas fronteiras. A cultura, portanto, é uma construção histórica relacionada às experiências e saberes de um povo, que compreende seus patrimônios simbólicos (a língua, a religião, as instituições, etc.) e participa de um processo continuado de transformações na esfera social.

É justamente no domínio histórico, considerando-se a cultura como resultado da articulação de ideias e valores cujos sentidos se traduzem no conjunto dos conhecimentos e 
tradições de um grupo social, que ocorre a convergência entre os conceitos de identidade cultural e língua. Kramsch (1998, p. 10) aponta para a primazia da língua como meio de expressão da cultura, definindo esta última como elemento de "uma comunidade discursiva que partilha um espaço social e história comuns [...]”.

Ora, a noção de uma comunidade discursiva historicamente organizada leva a pensar nas relações entre língua e identidade cultural e no modo como tais relações geram os próprios alicerces da sociedade, promovendo mecanismos institucionais, traçando os limites para o exercício de poder e, por fim, gerando a ideia mesma de civilização.

\section{Língua}

Nesse caso, há uma forte justificativa para retomar nesta discussão o trabalho de um dos grandes responsáveis pela inovação em teorias sociais no início do século XX, o linguista Ferdinand de Saussure. Para ele, os indivíduos não são os agentes por trás dos significados expressos através da linguagem, dado que esta abrange diversos domínios, apresentando um caráter "heteróclito e multifacetado" que impede que se possa classificá-la em qualquer "categoria de fatos humanos, pois não se sabe como inferir sua unidade" (SAUSSURE, 2006, p. 17).

Assim, a linguagem coloca problemas que pressupõem a investigação de outros campos disciplinares, como a história, a antropologia, etc., exigindo da linguística, enquanto ciência, a separação de um objeto de análise mais tangível e coeso. Esse objeto corresponde a uma parte essencial da linguagem, a língua, que pode ser definida como "um produto social da faculdade de linguagem e um conjunto de convenções necessárias, adotadas pelo corpo social para permitir o exercício dessa faculdade nos indivíduos" (SAUSSURE, 2006, p. 17). Em outras palavras, a língua é

[...] "um sistema de signos" - um conjunto de unidades que se relacionam organizadamente dentro de um todo. É a "parte social da linguagem", exterior ao indivíduo; não pode ser modificada pelo falante e obedece às leis do contrato social estabelecido pelos membros da comunidade (PETTER, 2010, p. 14).

A partir do postulado saussuriano da linguística da língua, programa em que esta é vista como um "sistema supraindividual que a sociedade impõe ao falante" (PETTER, 2010, p. 14), tornou-se mais claro o entendimento acerca das relações indissociáveis existentes entre língua e cultura. $\mathrm{O}$ contato entre os conceitos ocorre dialogicamente, com trocas constantes e 
constantes transformações, sendo a língua o principal veículo de transmissão da cultura. Para Brown (1994, p. 165), trata-se de duas instâncias que "estão intrinsecamente interligadas de modo que uma não pode se separar da outra sem a perda do significado da língua ou da cultura”.

Importa lembrar, todavia, que a ideia de identidade cultural não acompanha o conceito de cultura, tal como este foi legado pela tradição. A identidade cultural abrange as próprias noções de língua e cultura, pois integra os sentidos oriundos das relações verificadas entre ambas, os quais se refletem nos diferentes aspectos que particularizam um grupo social ou comunidade. No campo dos estudos culturais, além disso, devido às tendências e demandas postas pela época moderna, a ideia de identidade passou por uma significativa mudança, deixando de restringir-se aos limites traçados pela filosofia na antiguidade, para incorporar novas propostas trazidas pela sociologia e antropologia ${ }^{13}$.

\section{Identidade}

A identidade cultural se configura a partir de contextos socioculturais concretos, o que significa que o meio externo, o ambiente, desempenha função das mais relevantes nessa construção. São as manifestações culturais, as tradições, os costumes e crenças que ajudam a compor o imaginário de um povo, suas representações simbólicas e espirituais. Esses saberes, transmitidos, fundamentalmente, por meio da língua, são historicamente incorporados por um grupo social, definindo a identidade cultural que os distingue de outros grupos.

Assim surge a moderna concepção de cultura nacional, caracterizada pelo sentimento de pertencimento que experimentam os membros de uma comunidade expostos aos mesmos padrões de percepção da realidade social, dos valores e atitudes desenvolvidos ao longo do tempo. Na concepção de Stuart Hall (2006), um dos teóricos de maior prestígio no campo da antropologia,

As culturas nacionais, ao produzir sentidos sobre "nação", sentidos com os quais
podemos nos identificar, constroem identidades. Esses sentidos estão contidos nas
estórias que são contadas sobre nação, memórias que conectam seu presente com seu
passado e imagens que dela são construídas. Como argumentou Benedict Anderson
(1983), a identidade nacional é uma "comunidade imaginada" (HALL, 2006, p. 50,
grifo do autor).

13 Tais limites correspondem, mais precisamente, à noção restritiva de "unidade" a partir da qual se assumia a identidade na filosofia clássica, a exemplo da perspectiva aristotélica. 
Ainda segundo Hall (2006, p. 50, grifo do autor), uma cultura nacional é essencialmente "um discurso - um modo de construir sentidos que influencia e organiza tanto nossas ações quanto a concepção que temos de nós mesmos”. E é esta importante definição de identidade cultural que deve orientar o percurso reflexivo aqui proposto, uma vez que a premissa segundo a qual a "cultura nacional é um discurso" - assim como Kramsch fala em "comunidade discursiva" ao discutir o conceito - vem ao encontro da problemática posta por Édouard Glissant em suas obras, e de maneira mais acentuada em Le Discours antillais (1981), onde o sentido de "discurso" representa a inauguração de todo um pensamento de descoberta das fundamentos culturais antilhanos.

É importante ter em conta que os conceitos em análise são abertos e revelam-se em constante modificação. Sob a influência de variantes políticas e ideológicas, as relações entre estas noções, especialmente na sociedade moderna, têm sofrido significativas transformações, o que termina por atestar sua natureza permeável e dinâmica. Afinal, como sugere Santos (2006, p. 83), "se a cultura não mudasse, não haveria o que fazer senão aceitar como naturais as suas características, e estariam justificadas assim as suas relações de poder”.

A partir da década de 1960, graças às pesquisas divulgadas por Bakhtin e com o florescimento da linha de estudos sociolinguísticos, abriu-se uma nova perspectiva acerca das relações entre língua e cultura, que passou a integrar às discussões teóricas conceitos como discurso, comunicação e ideologia. A língua, enquanto alicerce das relações sociais, é também uma plataforma, um meio necessário e indispensável para que os indivíduos acessem a cultura, as tradições e os saberes da comunidade a qual pertencem, entrando, assim, em contato com sua identidade e referentes.

Como acontece com a cultura, o sentido da língua é a dinamicidade, a plasticidade, características que representam seu caráter mutável, de contínua transformação ao longo do tempo. Para Bakhtin, a língua está em permanente processo de construção e cabe aos falantes encaminhar tal processo:

[...] a língua não se transmite; ela dura e perdura sob a forma de um processo evolutivo contínuo. Os indivíduos não recebem a língua pronta para ser usada; eles penetram na corrente da comunicação verbal; ou melhor, somente quando mergulham nessa corrente é que sua consciência desperta e começa a operar. [...] Os sujeitos não "adquirem" sua língua materna; é nela e por meio dela que ocorre o primeiro despertar da consciência (BAKHTIN, 1997, pp. 107-108).

O que o autor chama de "despertar da consciência" poderia ser interpretado, sem prejuízo para o sentido da frase, como a descoberta da identidade cultural pelo membro da 
comunidade discursiva. Essa descoberta é mediada pela língua, que responde pela atualização e divulgação da cultura. Língua, cultura e identidade são, enfim, conceitos que mantêm entre si uma relação de interdependência, não podendo a cultura existir na ausência da língua ou a identidade sem que haja o contato formador entre ambas.

Sendo a identidade um aspecto manifesto pela relação imanente entre língua e cultura, não é de se admirar que estes dois conceitos tenham sido frequentemente debatidos nas extensas discussões sobre a questão identitária em teoria social. Tomados como termos moventes, isto é, sujeitos às transformações que ocorrem constantemente na trama das relações sociais, língua, cultura e identidade participam de um esquema reflexivo comum na confluência epistemológica de diferentes campos de estudo.

Por ocasião da emergência das políticas em cultural studies, estes conceitos passaram a ser vistos, mais especificamente, como "fenômenos sociais" inseparáveis e interdependentes, dada sua complexa articulação no âmbito das interações humanas.

Também segundo a perspectiva oferecida pelos cultural studies, isso a partir dos anos 1990, a ideia mesma de identidade cultural passou a ser problematizada e relativizada frente às profundas alterações observadas no contexto da modernidade. Stuart Hall (2006, p. 08), por exemplo, aborda o tema aceitando como premissa a afirmação de que "as identidades modernas estão sendo 'descentradas', isto é, deslocadas ou fragmentadas”. O autor argumenta que

Um tipo diferente de mudança estrutural está transformando as sociedades modernas no final do século XX. Isso está fragmentando as paisagens culturais de classe, gênero, sexualidade, etnia, raça e nacionalidade, que, no passado, nos tinham fornecido sólidas localizações como indivíduos sociais (HALL, 2006, p. 09).

Assim, Hall defende que a tradicional concepção de imutabilidade das identidades culturais já não é mais válida atualmente e tampouco pode ser aplicada com acerto ao sujeito moderno. Da mesma forma que seus termos análogos, a língua e a cultura, a identidade também sofre transformações, as quais "estão também mudando nossas identidades pessoais, abalando a ideia que temos de nós próprios como sujeitos integrados" (HALL, 2006, p. 09). Por fim, diz o pesquisador:

Esta perda de um "sentido de si" estável é chamada, algumas vezes, de deslocamento ou descentração do sujeito. Esse duplo deslocamento - descentração dos indivíduos tanto de seu lugar no mundo social e cultural quanto de si mesmos - constitui uma "crise de identidade" para o indivíduo (HALL, 2006, p. 09). 
O conceito de língua, neste processo de mudança, é percebido pelas novas teorias em formação como de fundamental importância para que se possa repensar as identidades culturais no plano contemporâneo. De acordo com Hall (2008):

As práticas de representação implicam sempre uma posição de onde se fala e de onde
se escreve - uma posição de enunciação. As recentes teorias de enunciação sugerem
que, ainda que falemos de nós mesmos e de nossa experiência, por assim dizer, "em
nosso nome", aquele que fala e o sujeito de quem se fala jamais são idênticos nem
estão exatamente no mesmo lugar. A identidade não é tão simples ou transparente
quanto pensamos. Talvez devêssemos, em lugar de concebê-la como um elemento já
plenamente constituído que as novas práticas culturais não fariam senão representar,
considerar a identidade como uma "produção" sempre em curso, jamais acabada, e
que se constitui no interior e não no exterior da representação. Esta visão problematiza
a autoridade e a autenticidade que reivindica o termo "identidade cultural" (HALL,
2008, p. 311).

Daí o resgate de alguns dos postulados da sociolinguística, principalmente quanto à cognição e à enunciação, em termos de representação simbólica do sujeito pela língua (considerada como veículo fundamental da comunicação social), para colocar em questão a identidade cultural.

\section{Injunções à problemática}

Ora, o pensamento de Édouard Glissant, nesse sentido, parece refletir muitas das colocações e propostas surgidas na esfera dos cultural studies, tais como a noção da multiplicidade das identidades, a dinâmica intercultural, a mobilidade conceitual que caracteriza a língua, a cultura e a identidade no cenário moderno. Pois Glissant sugere uma visão dos fenômenos sociais a partir do contato formador entre tradições e culturas diversas, sempre no caminho de uma pluralidade de discursos e ideias integrados ao esforço maior de afirmar o Diverso, que se traduz num modelo relacional da identidade - onde as noções de fragmentação e dissolução possuem grande ênfase. Na verdade, a ideia da diversidade, como sistema ou programa poético-filosófico em Glissant, baseia-se na contestação da unicidade do sujeito e da fixidez das identidades, ambos princípios canônicos.

Simpático à suposição de uma fragmentação das identidades modernas, Hall assinala:

O sujeito, previamente vivido como tendo uma identidade unificada e estável, está se tornando fragmentado; composto não de uma única, mas de várias identidades, algumas vezes contraditórias ou não-resolvidas. Correspondentemente, as identidades, que compunham as paisagens sociais "lá fora" e que asseguravam nossa conformidade subjetiva com as "necessidades" objetivas da cultura, estão entrando em colapso, como resultado de mudanças estruturais e institucionais. O próprio processo de identificação, através do qual nos projetamos em nossas identidades culturais, tornou-se mais provisório, variável e problemático. 
Esse processo produz o sujeito pós-moderno, conceptualizado como não tendo uma identidade fixa, essencial ou permanente. A identidade torna-se uma "celebração móvel": formada e transformada continuamente em relação às formas pelas quais somos representados ou interpelados nos sistemas culturais que nos rodeiam (HALL, 2006, pp. 12-13).

Particularmente no caso das comunidades e nações que emergiram dos escombros do mundo colonial, a questão da identidade, tanto em sua dimensão linguística quanto cultural, tornou-se objeto das mais amplas discussões. É sintomático que este tema tenha sido incorporado à agenda de órgãos internacionais como a Unesco, que passaram a tratar de aspectos relativos à soberania e autonomia, bem como aos direitos humanos, sob a ótica das relações identitárias entre grupos com um passado comum de dominação e imposições por países estrangeiros.

O indivíduo submetido às condições que caracterizavam o sistema colonial europeu, seja na África, nas Américas ou na Ásia, não podia contar com as mesmas referências partilhadas pelos demais povos, pois a própria formação histórica de suas comunidades e a conformação social eminentemente heteróclita de seu meio impedia a ideia de regularidade e permanência reclamada pela tradição antropológica para a exata definição do conceito de identidade.

Se, conforme visto até o momento, a identidade cultural não pode ser compreendida senão como o resultado da relação intrínseca entre a língua e a cultura, como então supor os contornos identitários entre povos etnicamente híbridos? É este questionamento fundamental que nutre a obra de pensadores e artistas como Aimé Césaire, Frantz Fanon, Édouard Glissant, Patrick Chamoiseau, Maryse Condé e Gisèle Pineau, entre tantos outros autores caribenhos que procuram problematizar e relativizar a questão das identidades culturais. Suas vivências e experiências nas Antilhas, espaço geográfico que metaforicamente reflete a fragmentação identitária do sujeito autóctone, trazem consigo os sinais distintos de uma percepção aguda e crítica da realidade social cujo exame é feito em suas produções.

O autor de Le Discours antillais concede à questão identitária um lugar destacado em sua obra, exigindo uma análise concentrada do tema e de suas implicações no ambiente das excolônias caribenhas. Seu olhar abrangente esmiúça as singularidades e subjetividades étnicoculturais antilhanas e contempla a dimensão que a pesquisa de identidade alcança naquele espaço e naquele contexto específico. A partir desta perspectiva, ou melhor, deste "lugar enunciativo", Glissant concentra-se no exame do real antilhano, por meio do qual busca 
reavaliar as ideias de pertencimento e memória, sempre necessárias à estruturação das identidades culturais.

É semelhante visão, portanto, que deverá nortear a investigação desta complexa problemática nas próximas etapas da pesquisa ora apresentada. 


\section{Capítulo II: O "caso antilhano": uma perspectiva histórica}

\section{A história como desafio}

As rupturas ou disjunções culturais e identitárias que caracterizam o Caribe sempre alimentaram as reflexões de intelectuais e literatos da região, que buscaram descrever um novo olhar acerca da problemática social e política latente naquele contexto. Glissant, particularmente, discute a questão segundo uma dupla operação: por um lado, retomando os vestígios da cultura africana decantados na comunidade antilhana em formação colonial; e por outro, elegendo um sistema discursivo capaz de integrar as noções de totalidade e multiplicidade à análise da experiência local vivida como uma "não-história".

$\mathrm{Na}$ semântica glissantiana, esses dois níveis epistemológicos correspondem a conceitos específicos que organizam um quadro de valores simbólicos e imagéticos relacionados à tentativa de descoberta ou criação de uma memória coletiva, tais como a Relação e o Diverso. Nesse sentido, é curioso observar como o autor define a cultura e ainda o modo segundo o qual interpreta as relações entre língua e identidade neste cenário insular de "abertura" que é o Caribe ${ }^{14}$.

Memória histórica e consciência coletiva são expressões análogas frequentes no texto de Glissant, onde surgem ligadas ao debate em torno da carência identitária do povo antilhano e à problemática cultural caribenha. Na origem dessa carência ou déficit está o desenraizamento dos povos africanos sob o tráfico, que o autor nomeia como transbord, isto é, o movimento descontínuo de passagem entre "as identidades culturais ou étnicas precedentes que definiam o quadro de vida, o conjunto de formas simbólicas que instituíam o mundo para os negros africanos, e [...] a situação de escravos que lhes foi imposta na América" (DAHOMAY, 2000, pp. 99-100).

Essa súbita mudança de condição, porquanto traumática, impediu a sedimentação de um sentimento de pertencimento ao lugar, bem como o desenvolvimento progressivo e regular de uma memória coletiva baseada na partilha de referentes comuns, levando à ruptura cultural e à perda de identidade. A perda em qualquer sorte irremediável dos laços interpessoais de

\footnotetext{
${ }^{14}$ Para Glissant (1981, p. 249), no Caribe "cada ilha é uma abertura". Significa dizer que cada parcela deste espaço insular é uma imagem viva da diversidade e da "multi-relação" que presidem o encontro de culturas e tradições no contexto antilhano.
} 
origem entre os indivíduos submetidos ao sistema escravagista e, mais ainda, a fratura cultural assim provocada, como considera Jacky Dahomay (2000), é

[...] tão mais trágica para o escravo por tudo ser feito para que ele não possa criar um mundo comum com outros escravos, os colonos reagrupando (pela força das coisas mais que pela vontade), nos espaços das plantações, africanos de origem étnica diferente que não falam então a mesma língua (DAHOMAY, 2000, p. 100).

Trata-se, pois, de um processo no qual o indivíduo se vê privado dos elementos básicos para poder expressar seus valores tradicionais e suas idiossincrasias culturais, um processo que despoja o sujeito de sua própria identidade, ao mesmo tempo em que cria situações que o impedem de restaurá-la ou de construir uma nova. Em outras palavras, "porque mercadoria, o escravo não possui o direito à uma identidade cultural, no sentido de identidade coletiva, e menos ainda a um mundo comum tal como ele poderia ser forjado num espaço político" (DAHOMAY, 2000, p. 100).

Essa situação colonial paradigmática, em que o dominador pretende por diferentes meios destituir o cativo de seus liames culturais para transformá-lo em objeto passivo e mais facilmente controlável ${ }^{15}$, levou a uma espécie de divórcio entre a comunidade local e a História ${ }^{16}$, ou a uma "querela com a História"17, como prefere Édouard Glissant. Ora, consiste esse atrito na impossibilidade de o povo antilhano, em virtude do referido processo de alienação a que foi submetido pelo colonizador na aurora de sua formação, haver criado cadeias temporais associativas entre o conhecimento objetivo de seu país (do qual dispunham) com uma "datação mesmo que mistificada desse país", de tal modo que "natureza e cultura não formaram para ele [aquele] todo dialético de onde um povo tira o argumento de sua consciência" (GLISSANT, 1981, p. 131).

A leitura que Glissant faz desse quadro sociocultural característico das colônias da América e, mais significativamente para ele, das Antilhas demonstra uma concepção de história

\footnotetext{
${ }^{15}$ Cumpre avaliar os meios de que se vale o colonizador para realizar este intento. Parece haver aí a instituição, através das práticas coloniais, inclusive discursivas, daquilo que Homi Bhabha (1998, p. 111) define como uma "forma de governamentalidade que, ao delimitar uma 'nação sujeita', apropria, dirige e domina suas várias esferas de atividade", servindo ao propósito de tornar o colonizado "apreensível" e inteiramente passivo.

${ }^{16}$ Em Glissant, quando grafada com "h" maiúsculo, esta palavra expressa o caráter unívoco, totalizante, linear e hierarquizado que lhe foi atribuído pela tradição ocidental em termos de uma construção discursiva de exercício de poder. O autor rejeita tal concepção, dizendo: "A História é um fantasma fortemente operante no Ocidente, contemporâneo precisamente ao tempo em que este era o único a 'fazer' a história do mundo" (GLISSANT, 1981, p. 132).

17 "La querelle avec l'Histoire" corresponde à entrada da seção 27 de Le Discours antillais, onde o autor discute a problemática cultural e identitária nas Antilhas a partir do conceito de história, que procura relativizar. Seus apontamentos, conforme indica, tiveram por base o texto de Edward Baugh "The West Indian Writer and his Quarrel with History” (1976), lido no Colóquio Carifesta de Kingston naquele ano.
} 
baseada na ligação orgânica entre o indivíduo ou grupo e seu lugar de pertencimento, implicando a construção de um sentido particular de valores tradicionais (língua, religião, costumes) a partir de um tempo, de uma periodização, de um calendário, em suma, que responda por uma cronologia. Para o autor, é justamente a ideia de cronologia que sustenta a história, por pressupor a existência de uma relação dialética entre natureza e cultura, na qual se assenta a noção mesma de comunidade.

A problematização da história no contexto em causa, contudo, não significa sua negação, mas antes a tentativa de um resgate ou restabelecimento da cronologia antilhana. A "não-história" local diz respeito, assim, às sucessivas rupturas experimentadas por aquela comunidade, pela dramática disjunção entre natureza e cultura ali observada e, consequentemente, pela impossibilidade de consolidação de uma memória coletiva. Vale lembrar, a esse propósito, a lúcida e consistente introdução que Glissant propõe ao acercar-se desta questão:

Se é incongruente pretender que um povo "não tem história", pode-se sustentar que, em certas situações contemporâneas, agora mesmo que um dos dados do alargamento planetário é a presença (e o peso) da consciência histórica cada vez mais generalizada, um povo seja confrontado com a desordem dessa situação que ele pressente que lhe é "necessária", mas que ele é incapaz de "fazer emergir" ou de "fazer passar no cotidiano": porque os dados imediatos desse cotidiano não se inscrevem para ele em um continuum, isto é, que sua referência ao entorno (isto que chamaríamos sua natureza) está em uma relação descontínua com a acumulação de suas experiências (isto que chamaríamos sua cultura). Num tal contexto, a história enquanto disciplina e na medida em que ela pretende aclarar a realidade que vive esse povo sofrerá de uma carência epistemológica grave: ela não saberá por qual meio se fixar (GLISSANT, 1981, p. 130).

Segundo essa visão, o descompasso na relação referencial do indivíduo com seu meio (natureza) e a acumulação de suas experiências (cultura) determina um tipo de "curto-circuito paralisante" da história tradicional (GLISSANT, 1981, p. 130), uma vez que esta revela-se insuficiente diante de tal conjuntura, padecendo daquilo que Glissant considera como uma grave "carência epistemológica". O fato de não haver uma cadência, um continuum, em que possam figurar as experiências do grupo conduz à imediata "rasura da memória coletiva" (GLISSANT, 1981, p. 131), ou seja, ao apagamento da consciência histórica e à dissolução do tempo cronológico. O autor exemplifica essa situação referindo-se ao desvanecimento de grandes episódios do passado da memória popular antilhana, justamente em razão das constantes rupturas compreendidas pela "não-história" local:

O fator negativo desta não-história é então a rasura da memória coletiva. Quando o coronel Delgrès saltou com seus trezentos homens sobre o paiol do Forte Matouba em Guadalupe (1802), para não se render aos seis mil soldados franceses que os cercavam, o ruído dessa explosão não reverberou imediatamente na consciência dos 
martiniquenses e guadalupenses. É que Delgrès foi vencido uma segunda vez pelo subterfúgio silencioso da ideologia dominante, que chegou por um tempo a desnaturalizar o sentido de seu ato heroico e a apagá-lo da memória popular. Assim, a proclamação do governo francês aos escravos martiniquenses (março de 1848) afirma que os guadalupenses reclamaram eles mesmos o restabelecimento da escravidão em 1802. E quando os heróis antilhanos, Toussaint ou Marti, foram vitoriosos, isso não foi senão em seus respectivos países. O bloco ideológico funcionou tanto quanto os blocos econômicos ontem para o Haiti e hoje para Cuba. Se Bolívar conseguiu ajuda e repouso no Haiti, se então por um tempo a ideia de uma história antilhana global se concretizou, esse tempo não durou nada. Hoje, portanto, nós percebemos o estrondo de Matouba (GLISSANT, 1981, p. 131).

Essa frase final deve ser especialmente sublinhada, pois aponta para um percurso a ser seguido pela comunidade antilhana na busca pelo tempo de sua história, por conseguinte de sua cronologia, que vem a constituir o alicerce de toda identidade cultural. De modo mais amplo, o trecho parece ilustrar com precisão aquilo que Paul Ricœur (2007, p. 93) chama de “manipulação concertada da memória e do esquecimento por detentores de poder", o procedimento dos dominadores baseado no agenciamento ideológico da consciência histórica. Contra isso, Glissant sugere efetivamente um movimento de desconstrução da trama ideológica colonial, sob cuja superfície se encontraria um sentido próprio e independente para a memória coletiva naquele contexto.

\section{A história como "urgência"}

$\mathrm{Na}$ verdade, este ponto de vista alimentou também o trabalho de jovens escritores martiniquenses que, no início dos anos 1990, propuseram uma nova interpretação da história antilhana. Estes autores, Jean Bernabé, Patrick Chamoiseau e Raphaël Confiant, assinaram o revolucionário manifesto Éloge de la créolité (1989), no qual afirmam: "Nossa História (ou mais exatamente nossas histórias) está naufragada na crônica colonial. A memória coletiva é nossa urgência. Aquilo que acreditamos ser a história antilhana não é senão a história da colonização das Antilhas" (BERNABÉ, CHAMOISEAU, CONFIANT, 1993, p. 37). Ora, é fácil perceber o quanto a tríade foi sensível ao pensamento glissantiano, compreendendo o alcance da ideia de memória coletiva e a "urgência" de instituí-la como um dado da realidade.

Separar a matéria ideológica colonial da matéria cronológica local, isto é, aquilo que é produto das estratégias de dominação do colonizador daquilo que responde por uma memória lastreada em tradições ancestrais, é o grande desafio proposto por Glissant como parte da vasta reivindicação identitária que permeia sua obra. Nesse âmbito, a constituição de um discurso 
sobre a formação cultural é um imperativo para a comunidade antilhana, e mormente para os Departamentos franceses ${ }^{18}$, onde a procura da identidade resta em curso.

Logo, ao discutir a questão, o autor faz mais do que descrever um quadro sociopolítico particular, propondo um verdadeiro projeto - por que não dizê-lo - de emancipação histórica por meio de um discurso social preciso, que corresponde à "urgência". Nessa dicção, diz o autor:

A memória coletiva é nossa urgência: falta, necessidade. Não apenas o detalhe "histórico" de nosso passado perdido (não isso somente), mas os fundos ressurgidos: a extirpação à matriz África, o homem bífido, a medula remodelada, a mão violenta inútil [...].

O relato minucioso das datas e dos fatos nos ocultam o movimento contínuo (a significação árdua, a qual amiúde nos recusamos) de nosso passado. Tudo esquecer de sua história: essa graça nos é interdita, pois nada aprendemos (GLISSANT, 1969, p. 187, grifo do autor).

Vê-se que a "urgência" a que se refere corresponde a uma necessidade premente da sociedade antilhana, a necessidade de uma história independente e não determinada pelo colonizador, uma história, em resumo, que possa conferir a essa sociedade voz cultural e feição identitária próprias. Nesse sentido, o "pensamento da urgência" sobressai como um fio condutor do trabalho de Glissant. Seja em sua diversificada produção ficcional, seja no conjunto ensaístico de seu trabalho, o escritor procura preparar essa base histórica tão imperativa para os antilhanos.

Desde a publicação de romances como La Lézarde, passando por O Quarto Século e Malemort, até La Case du commandeur, é flagrante a busca pela memória coletiva e pela identidade cultural; paralelamente, seus textos críticos, ensaios e reflexões filosóficas, os quais nomeia como sua "Poética", inauguram um discurso e um modo de interpretar a realidade comprometidos antes de tudo com a afirmação da pluralidade e da partilha.

Não por acaso, a questão se cristaliza no discurso glissantiano como signo de uma demanda pela liberação da consciência das Antilhas, não meramente em caráter revisionista (aquilo que o autor trata como "um pranto nostálgico" do passado), mas enquanto plataforma para a efetiva formulação do presente e do futuro antilhano:

Nosso futuro nos impacta com uma brusquidão que atordoa. A emergência desta unidade difratada (desta conjunção despercebida de histórias) que constitui as Antilhas neste momento nos surpreende, antes mesmo que tenhamos meditado essa conjunção. Significa dizer também que nossa história é presença no limite do

\footnotetext{
18 Pela Lei de Assimilação de 1946, portanto no contexto do pós-guerra, a Martinica passou à condição de Departamento, o que, para Glissant (1981, p. 335), correspondeu "a uma mudança profunda na maneira como os martiniquenses se veem e concebem suas relações com o outro”.
} 
suportável, presença que devemos religar sem transição à trama complexa de nosso passado. O passado, nosso passado sofrido, que não é ainda história para nós, é no entanto aí (aqui) que nos lancina. A missão do escritor é explorar esse dilaceramento, é "revelá-lo" de maneira contínua no presente e atual. Essa exploração não vem então nem para uma esquematização nem para um pranto nostálgico. Vem para deslindar um sentido doloroso do tempo e para projetá-lo tão logo em nosso futuro, sem o recurso destas sortes de praias temporais que os povos ocidentais beneficiaram, sem o seguro desta densidade coletiva que dá antes um país cultural ancestral. É isto que eu chamo uma visão profética do passado (GLISSANT, 1981, p. 132).

O pensador sugere que a compreensão do passado, sua investigação crítica, longe de confinar o sujeito à situação de "prisioneiro da História" ou de "escravo da Escravidão", como propõe Fanon (2008, pp. 189-190), é uma premissa para o estabelecimento dos alicerces do futuro antilhano. $\mathrm{O}$ indivíduo deve antes desenvolver a consciência dos entrecruzamentos de histórias que constituem a "trama complexa" do passado daquela comunidade, para então ser capaz de elaborar seu porvir social, político e cultural. A missão que Glissant define para o escritor é a missão pessoal que leva a cabo em sua própria obra, a árdua missão de dar às Antilhas um passado, revelando um sentido histórico decisivo tanto para o presente quanto para o futuro projetado.

Para o autor martiniquense a busca da identidade cultural parece ser indissociável da pesquisa histórica. Como referido, já em seus primeiros escritos, Glissant oferece margem a essa interpretação, sendo suficiente lembrar que o protagonista de La Lézarde, o jovem Mathieu Béluze, é nada mais nada menos do que um historiador envolvido na tarefa de reconstituir o passado de seu povo. Na verdade, a perspectiva da "urgência" descortinada em L'Intention poétique e assumida por uma nova geração de escritores antilhanos admite em seu cerne o exame da história, do passado, como meio para a construção da memória coletiva. Conforme expressa Gisèle Pineau em sua prosa ficcional, a consciência da história independente das Antilhas leva ao entendimento profundo e legítimo da identidade da comunidade local: "Digame a história verdadeira, eu a escreverei para aqueles que vêm... Eu me farei papel, tinta e caneta para entrar na carne do país" (PINEAU, 1996, p. 168).

\section{Uma nova etapa}

No debate acerca da problemática identitária nas Antilhas, Le Discours antillais inaugura uma nova etapa, onde a questão linguística e cultural é perspectivada pelo viés histórico da formação da comunidade local. Glissant, nesse caso, procura responder à "urgência" antilhana através de uma tradução não hierarquizada e não linear da história, 
portanto avessa à tradicional concepção ocidental da disciplina. Segundo indicado anteriormente, o autor propõe uma leitura dialética da história do Caribe, mesmo por se tratar de uma necessidade colocada pelo próprio sentido da conformação daquela comunidade. Afinal, essa leitura dialética faz face à exigência daquilo que o autor considera ser indispensável ao assentamento de todo grupo social, a "conjunção dinâmica natureza-cultura" (GLISSANT, 1981, p. 132).

O trabalho sobre a identidade antilhana se faz paralelamente à defesa da multiplicidade cultural no contexto da modernidade, o que situa o pensamento de Glissant nas imediações dos estudos culturais e das políticas identitárias. Em seu projeto "poético" o autor faz a leitura da diversidade que toma espaço na atualidade a partir da própria "experiência da diversidade" vivida nas Antilhas, experiência essa que concentra uma visão multiforme da realidade sociocultural do mundo. Assim, a descoberta da história e da identidade locais desdobra-se num modo complexo de interpretação da realidade cultural global, marcada por entrecruzamentos, intercâmbios, conjunções, ou mais precisamente, pelo movimento que Glissant nomeia como “crioulização".

Toda abordagem dessa questão em Édouard Glissant deve, portanto, passar pelo crivo do Diverso e da Relação, conceitos que elabora para discutir a determinação diacrônica das novas culturas deflagradas pelo colonialismo, as quais cobram uma mobilização crítica satisfatória para descrever, no presente, aquilo que estabelece os próprios conceitos de cultura e identidade na (para a) modernidade. Daí a urgência de um encontro positivo e eficiente entre teoria e objeto, com a promoção de uma perspectiva suficientemente ampla para abranger as imprevisíveis variações dos fenômenos sociais surgidos na esfera mundial. 


\section{Capítulo III: Duas frentes de abordagem da questão identitária antilhana}

\section{Fundamentos}

A leitura crítica da obra de Glissant faz ver que o desenvolvimento da discussão acerca da questão identitária antilhana pelo autor se configura segundo duas vias epistemológicas, sendo a primeira delas a crítica histórica e a segunda a crítica filosófica. Entende-se, aqui, por crítica histórica a abordagem da questão sob a ótica do processo histórico de formação e organização da comunidade local, considerados os aspectos que caracterizam tal processo, entre os quais se destacam o estabelecimento das instituições, a implementação de leis e códigos sociais, a criação dos símbolos que representam a unidade e identidade nacionais, etc. Já a crítica filosófica diz respeito à avaliação do problema suscitado a partir de suas ressonâncias na esfera das atividades intelectuais realizadas no interior da comunidade, isto é, a partir de sua problematização no campo das ciências humanas e das artes, especialmente a filosofia, a linguística e a literatura. Nesse sentido, valem como metáforas da atitude de Glissant diante das perspectivas exploradas (a crítica histórica e a crítica filosófica) dois conceitos fundamentais: alteridade e diversidade ${ }^{19}$.

\section{Crítica histórica}

A ideia de alteridade relaciona-se à crítica histórica da relação entre língua e identidade cultural em Le Discours antillais e, diga-se, ao longo da obra de Glissant tomada integralmente, no sentido de uma interação dialógica entre o Eu e o Outro, isto é, no sentido de integrar o Outro ao processo de construção identitária, e não de excluí-lo do mesmo. Cumpre lembrar que já em L'Intention poétique, texto de 1969, Glissant discutia a alteridade sob essa luz, dizendo: “O Outro está em mim, porque eu sou eu. Assim, o Eu perece, quando o Outro está ausente" (GLISSANT, 1969, p. 101).

Daí o fato de o autor considerar que o "pensamento do Outro é a generosidade moral que me inclinaria a aceitar o princípio da alteridade, a conceber que o mundo não é feito de um

\footnotetext{
${ }^{19}$ Isso de acordo com a observação feita por James Tully (2000, p. 195): “a identidade não é jamais completamente idêntica a ela mesma: ela contém sempre um irredutível elemento de alteridade. A identidade é múltipla, ela apresenta diversas facetas".
} 
bloco e que ele não é senão uma verdade, a minha” (GLISSANT, 1990, p. 169). Assim, a alteridade surge, através da proposta teórica desenvolvida por Glissant e formalizada nos moldes de uma poética da Relação, como elemento crucial para a abordagem e discussão do problema da identidade.

A definição das marcas de identificação de um grupo social se dá pelo seu contato com outros grupos em contextos amplamente diversificados, sendo preciso observar nessa dinâmica intergrupal, conforme sugere Viertler (2006, p. 47), dois níveis: “o primeiro, o das causas mais profundas, que explicam a emergência de estigmas, estereótipos e atributos sociais; o segundo, o dos conteúdos concretos, muito variáveis no decorrer do processo histórico". Essas marcas podem se referir a certas especificidades do ambiente físico ou ainda a certos hábitos e costumes que participam da construção do sentido de cultura e, por extensão, de identidade, no âmbito de um grupo ou comunidade.

Ao identificar-se com dadas caraterísticas, o indivíduo se insere em determinado “espaço do cosmo" (VIERTLER, 2006, p. 48) e com isso ajuda a forjar as fronteiras étnicas que irão distinguir seu próprio grupo dos demais existentes, isso em termos sociais, históricos, linguísticos, etc. Cabe considerar, portanto, que o fenômeno das identidades culturais se explica por meio das relações de alteridade, sempre envolvendo a ideia de pertencimento do sujeito ou grupo a um cenário particular da vida social. Assim, de acordo com Viertler,

[...] a identidade do indivíduo, a consciência que ele tem de si mesmo, repousa sobre um processo dialético entre ele, Ego, e um outro, Alter, sem mencionar as clivagens que nele existem entre aspectos conscientes, subconscientes e inconscientes do seu psiquismo. E, se considerarmos Alter, o outro, os referenciais externos que acabaram sendo internalizados pela experiência social do Ego, compreenderemos em termos mais profundos atitudes, motivações e sentimentos humanos criados por estímulos que podem tanto ser reais, quando decorrentes da história de vida do indivíduo, quanto imaginários, quando emergem de construções simbólicas e representações criadas pelo grupo social a que pertence. A consciência de si mesmo corresponde a um sujeito clivado, espelhando-se em outros. Ao falar de alteridade, o sujeito afirma algo sobre si mesmo, expressão de sua própria identidade (VIERTLER, 2006, p. 48).

Na crítica histórica, Glissant problematiza a questão das identidades culturais a partir das rupturas político-ideológicas que acompanharam a formação das colônias caribenhas desde seus primórdios e que encetaram aquilo que Hall (2008, p. 313) nomeia "experiência da dispersão e fragmentação" pelas diásporas forçadas, ou seja, a experiência de “desenraizamento" sofrida pelos povos africanos escravizados, os quais vieram a compor uma comunidade multiétnica carente de referências culturais e históricas que pudessem lhes assegurar as noções de memória e pertencimento, indispensáveis ao sentido de identidade. Refletindo sobre essa questão, diz Glissant: 
As Antilhas são o lugar de uma história de rupturas cujo começo é uma extirpação brutal, o tráfico de escravos. Nossa consciência histórica não podia se "sedimentar", se assim se pode dizer, de maneira progressiva e contínua, como entre os povos que engendraram uma filosofia geralmente totalitária da história, os povos europeus, mas se agregava sob os auspícios do choque, da contração, da negação dolorosa e da explosão. Esse descontínuo no contínuo, e a impossibilidade para a consciência coletiva percorrê-lo, caracterizam isso que chamo uma não-história (GLISSANT, 1981, pp. 130-131).

O movimento convulsivo designado pelas expressões "choque", "contração", "negação" e "explosão", remete ao déficit histórico dos povos caribenhos, que, "nascidos do ato colonial" (GLISSANT, 1981, p. 131), na ausência de referentes linguísticos, religiosos, de valores tradicionais comuns, não lograram estabelecer sua episteme cultural, opondo resistência aos dominadores e, simultaneamente, afirmando sua própria identidade.

Este movimento presente em Glissant e já observado na obra de autores como Frantz Fanon participa de uma concepção de identidade cultural que está no centro dos embates póscoloniais e mesmo do projeto político de emancipação das comunidades caribenhas. Tal concepção pode ser assumida, conforme propõe Hall, segundo duas maneiras distintas, sendo que a primeira define a ideia de identidade cultural em termos de "cultura partilhada, isto é, como uma espécie de 'verdadeiro eu' coletivo que se dissimularia em diversos outros 'eu' impostos, superficiais e artificiais, que dividem aqueles que têm uma história e ancestrais comuns" (HALL, 2008, p. 312). Ainda de acordo com o pesquisador:

Segundo os termos desta definição, nossas identidades culturais refletem as
experiências históricas comuns e os códigos culturais partilhados que nos fornecem -
nós, no sentido de "um só povo" - quadros estáveis, imutáveis e contínuos de
referência e significação, para além das divisões e das vicissitudes da história real
(HALL, 2008, p. 312).

As "experiências históricas comuns" no caso das comunidades caribenhas, no entanto, estão restritas a "deportação, a escravidão e a imigração" (HALL, 2008, p. 313) que compreendem o "drama da separação e da "perda de identidade"” (HALL, 2008, p. 313) dos povos africanos que vieram a constituí-las, os quais, oriundos de civilizações diferentes em seu continente de origem, não puderam também partilhar os mesmos códigos culturais, não tendo assim acesso aos quadros de referência estáveis necessários à integração de qualquer grupo social. Daí o dilema vivido pelos membros dessas comunidades compósitas iniciadas a partir de um colapso de enormes proporções - a diáspora forçada - e o sentimento de perda e desorientação que nutriram face à "história interrompida de [seu] passado" (HALL, 2008, p. 313).

A partir desta perspectiva, pode-se explorar a segunda concepção de identidade cultural apresentada por Stuart Hall, a qual 
[...] reconhece que existem, ao mesmo tempo em que muitos pontos de similitude, numerosos pontos críticos de diferença profunda e significativa que constituem "aquilo que somos realmente" ou antes - porquanto a história teve lugar - "aquilo que nos tornamos". Assim, não é mais possível evocar "uma experiência", "uma identidade", sem reconhecer sua outra face: as descontinuidades e rupturas que constituem precisamente a "singularidade" caribenha. A identidade cultural, conforme esta segunda acepção, revela tanto do "ser" quanto do "devir". Ela pertence ao futuro tanto quanto ao passado. Não é algo que já existe e que seria transcendente ao lugar, ao tempo, à história e à cultura. As identidades culturais vêm de qualquer parte, elas têm histórias. Destarte, como tudo que é histórico, elas se fazem também objeto de transformações. Longe de estarem fixadas para a eternidade em algum passado essencializado, elas estão sujeitas ao "jogo" contínuo da história, da cultura e do poder. Longe de estarem fundadas sobre uma simples "redescoberta" do passado, que aguardaria ser feita, e que, logo que o fosse, asseguraria para a eternidade nosso sentimento de sermos nós-mesmos, as identidades são os nomes que damos às diversas maneiras de sermos situados pelos relatos do passado e de ali nos situarmos (HALL, 2008, p. 314, grifo do autor).

Nessa linha pode ser lida, precisamente, a noção de alteridade em Glissant. O autor, ao discutir as relações entre língua e cultura, assume que não há como pensar as identidades culturais segundo uma ótica parcial, forjada na noção de unicidade tão cara à tradição ocidental, mas, contrariamente, é necessário admitir o conceito a partir de uma multiplicidade de pontos de vista, o que permite abarcar a ideia em sua total extensão e, desse modo, compreender o processo corrente de transformação das identidades em sentido plural e dialógico.

Esse modelo vem, portanto, sustentar a proposta de relativização do passado colonial das Antilhas - aspecto este que alimenta as reflexões de Hall:

As diferentes maneiras pelas quais o povo negro e as experiências negras se situaram e subordinaram nos regimes dominantes de representação foram o resultado de um exercício crítico do poder e da normalização culturais. Nós não fomos apenas construídos por esses regimes, no sentido "orientalista" de Said, como outros e diferentes no seio das categorias do saber ocidental; houve também por consequência que fôssemos nós mesmos vistos e vividos como "Outro". Todo regime de representação é um regime de poder formado, como recorda Foucault, pelo par fatal "saber-poder". Mas esse tipo de saber é interno e não externo. Uma coisa é situar um sujeito ou um povo como "Outro" em um discurso dominante; outra é submetê-lo a esse "saber", não somente em meio a uma dominação e uma vontade impostas, mas também por uma inflexão interna e uma conformação subjetiva à norma (HALL, 2008, p. 314, grifo do autor).

No seio da crítica histórica, a ideia de alteridade participa, portanto, de um movimento epistemológico de reavaliação das identidades culturais no âmbito antilhano, trazendo os conceitos de experiência, memória e discurso como vetores de uma intensa redescoberta cultural. Segundo Hall:

Esta ideia de alteridade como confronto interno modifica nossa concepção de “identidade cultural". Nesta perspectiva, esta não é absolutamente uma essência fixa que repousaria, imutavelmente, no interior da história e da cultura. Ela não é em nenhum caso uma espécie de espírito universal e transcendente que portaríamos em nós e sobre o qual a história não teria deixado marca fundamental. Ela não é uma vez por todas. Ela não é uma origem fixa a partir da qual poderíamos fazer, de maneira 
absoluta e definitiva, retorno. Bem entendido, ela tampouco é um fantasma. O passado continua a nos falar. Simplesmente, ele não se dirige a nós como um simples "passado" factual, pois nossa relação com esse passado, como a de uma criança com sua mãe, se situa sempre "depois da ruptura". Ela é sempre construída por meio do relato, do mito, da memória e da imaginação. As identidades culturais são os pontos instáveis de identificação ou de sutura no coração dos discursos culturais ou históricos. Não uma essência, mas um posicionamento (HALL, 2008, p. 315, grifo do autor).

Desta feita, a identidade se constrói historicamente, portando as marcas de cada período e processo, de modo que não se mantém fixa no tempo, mas transforma-se produtivamente e desdobra-se em nova identidade. A ideia de partilha de determinadas constantes identitárias, nesse sentido, deve-se a memória que se constrói e reafirma ao longo das épocas através do discurso, em sua simbiose com a própria ideia de cultura.

\section{Crítica filosófica}

O questionamento de Glissant face à noção tradicional de identidade justifica-se, nesse sentido, por uma tomada de consciência da realidade social das Antilhas e pela consequente proposição de um novo modo de olhar a questão identitária, que vem a constituir o núcleo do pensamento glissantiano. $\mathrm{O}$ autor assume que, no cenário contemporâneo, a ideia de identidade não pode ser concebida senão em termos de pluralidade, multiplicidade, heterogeneidade e variação, opondo-se, assim, à visão consagrada que determina a particularidade, a homogeneidade e a permanência como predicados absolutos do conceito ${ }^{20}$.

Em outras palavras, Glissant defende a revisão epistemológica do princípio e sua passagem do plano da identidade enquanto raiz para o plano da identidade enquanto rizoma, isto é, do plano linear e fixo definido pela tradição para um plano mais vasto e dinâmico ${ }^{21}$. Destarte, como base da crítica filosófica, nasce a Relação, conceito forjado pelo autor martiniquense que procura sugerir que o sentido de toda identidade é dado pelo contato com o Diverso, num processo contínuo de trocas e assimilação dirigido a uma construção linguística e poética que encontra na latência e na relatividade seus fundamentos indispensáveis.

\footnotetext{
${ }^{20}$ Valeria antecipar a seguinte reflexão assentada por Deleuze e Guattari (1995, p. 17) acerca do que foi dito neste parágrafo: "A noção de unidade aparece unicamente quando se produz numa multiplicidade uma tomada de poder pelo significante ou um processo correspondente de subjetivação: é o caso da unidade-pivô que funda um conjunto de correlações biunívocas entre elementos ou pontos objetivos, ou do Uno que se divide segundo a lei de uma lógica binária da diferenciação no sujeito".

${ }^{21}$ A proposta de distinção entre as noções de raiz e rizoma é apresentada por Gilles Deleuze e Felix Guattari no primeiro volume de Mil Platôs, obra publicada em 1980. Uma observação mais atenta das implicações desta proposta no pensamento glissantiano será feita no capítulo $\mathrm{V}$ da presente pesquisa.
} 
Os fundamentos da poética da Relação surgem, ainda em germe, na seção 45 de $L e$ Discours antillais - precisamente sob o frontispício "Poética da Relação" -, onde Glissant parte da noção de uma poética do texto oral africano para discutir o relativismo no espaço-tempo das narrativas oriundas dessa tradição. $\mathrm{O}$ autor sugere a existência de um elemento nuclear, o "dizível”, o qual participa de um regime que nomeia "poética da duração", e cujo papel nas narrativas épicas ancestrais seria o de manter e preservar a memória comum ao povo que as partilha. Por contraste, no discurso ocidental detecta o "indizível", presente numa "poética do instante", que se opõe àquele fundamento presente no texto oral africano, havendo aí uma distinção entre instâncias epistemológicas particulares.

Nesses relatos primeiros de uma tradição, a palavra possuía um sentido profundo, comunicado entre os membros da comunidade discursiva em que se manifestava, e guardava a própria expressão das características culturais e identitárias dessa comunidade, assegurando sua "legitimidade no mundo" (GLISSANT, 1981, p. 247). Mas o mistério da palavra oral, considera Glissant, acabou sendo penetrado e dissipado pela ação do colonizador europeu, que, participante de um sistema filosófico racionalista, não podia "conceber a poética, que [1he] parecia fraqueza e renúncia (GLISSANT, 1981, p. 247).

A oposição entre o sentido da palavra entre os povos africanos e a organização do discurso entre os ocidentais é, então, marcante e reveladora de uma dissimetria nas relações sociais estabelecidas a partir da experiência colonial:

Na poética do texto oral africano tudo é dizível. [...]

O indizível poético me parece consagrado no ocidente a isso que se chama a dignidade da pessoa humana, ela mesma transcendida a partir da aparição histórica da propriedade privada. Essa abreviação audaciosa nos permite supor que a paixão poética, enquanto exigência de um eu, prevê de início que a comunidade esteja despojada de seu direito fundamental de estabelecer e esteja organizada à volta de direitos privados. O indizível poético é a economia suprema do direito de propriedade. Paradoxalmente, ele é transparência e não opacidade.

Eu constantemente opus a esse sentido agudo da pessoa humana o sentimento não menos forte do consentimento à dignidade comum, tal como me pareceu se afirmar em muitas civilizações não ocidentais. No percurso propriedade privada - dignidade da pessoa - indizível poético, eu oporia um outro que me parece igualmente fundador: indivisibilidade da terra - dignidade da comunidade - explicitação do canto. Uma tal oposição civilizatória permitiria também compreender as rupturas na civilização antilhana, onde a herança africana (do sentimento da dignidade comum) colidia com um impossível (a não possessão coletiva da terra) e onde a explicitação do canto (a cultura oral tradicional) estava barrada pela educação ocidental (a iniciação ao indizível poético) (GLISSANT, 1981, p. 248).

No sistema colonial, o produto deste processo, conforme defende Glissant, seria a ideia contrária às subjetividades individuais e às particularidades identitárias, nomeada "universal generalizante". Assim, o détour feito por Glissant pela tradição das narrativas orais africanas 
pode ser explicado pela necessidade de se descrever o quadro das relações sociais (lastreadas no plano discursivo), não apenas para melhor investigar a natureza das "rupturas na civilização antilhana", como também para problematizar a questão das identidades linguística e cultural naquele cenário/contexto. No programa da poética da Relação, faz-se então a crítica do universal generalizante, no sentido de afirmação das identidades possíveis:

O universal generalizante é a pretensão suficiente que permite sublimar a dignidade da pessoa a partir da realidade da propriedade privada. É também a arma mais concludente no processo de despersonalização de um povo despojado. Contra o universal generalizante o primeiro recurso é a vontade áspera de permanecer no lugar. Mas o lugar, naquilo que nos concerne, não é somente a terra onde nosso povo foi deportado, é também a história que ele partilhou (vivendo-a como não-história) com outras comunidades, cuja convergência aparece hoje. Nosso lugar é as Antilhas (GLISSANT, 1981, p. 249).

O modelo relacional das identidades culturais proposto por Édouard Glissant compreende, por isso, a noção de diversidade como principal veículo conceitual da crítica filosófica, assim como a ideia de alteridade surge para a crítica histórica. A diversidade é, em outras palavras, um verdadeiro conceito-chave assumido como contraponto a tendência à parcialidade e unicidade dominante na visão histórica ocidental. Afinal, como lembra Joan Scott (1995, p. 05): “'Diversidade' refere-se a uma pluralidade de identidades, e é vista como uma condição da existência humana e não como o efeito de uma enunciação de diferença que constitui hierarquias e assimetrias de poder".

É a partir da diversidade que Glissant concebe a ideia de identidade, pensada em termos de memória e sentimento de pertencimento:

A antilhanidade, sonhada pelos intelectuais, ao mesmo tempo que nossos povos a viviam de maneira subterrânea, nos desvencilha da intolerância própria aos nacionalismos necessários e nos introduz à Relação, que, hoje, os atenua sem alienálos.

O que são as Antilhas, com efeito? Uma multi-relação. Nós todos o percebemos, nós o exprimimos sob toda sorte de formas ocultas ou caricaturais, ou nós o negamos tenazmente (GLISSANT, 1981, p. 249).

É também a partir da diversidade que o autor discute a relação entre língua e cultura (discurso e tradição) e suas implicações para a noção mais ampla de identidade cultural:

E assim como penso que a fulguração poética é o acme da exaltação do eu, do mesmo modo posso eu conjecturar que o permanente retorno do discurso é a medida de um Nós. Mas esse Nós não se dá como transcendência. Estamos mesmo no direito de afirmar que ele supõe por natureza este dado primeiro da Relação que é a mestiçagem (GLISSANT, 1981, p. 250).

A diversidade é uma proposição discursiva que engloba diferentes conceitos formulados por Glissant (desde a Relação até o Diverso, passando pelo Todo-mundo, até a 
“criulização" e o pensamento-arquipélago) e por meio da qual o autor expressa sua visão de mundo pluralista, voltada para a integração e o diálogo intercultural.

\section{Articulação entre as perspectivas}

Então, com base na crítica histórica, articulada à noção de alteridade, Glissant pôde repensar as tradicionais categorias do $\mathrm{Eu}$ e do Outro, que veio a problematizar na crítica filosófica, cuja articulação com a noção de diversidade ajudou a construir um sentido de Todo, que preserva tanto o Eu quanto o Outro sem os opor. A diversidade, enquanto instância da poética da Relação, se faz uma solução para o dilema da alteridade - por meio deste conceito Glissant explora caminhos alternativos que o levam a conceber que não há universalidade e sim uma "totalidade-mundo" 22 e, principalmente, que na construção identitária "todas as culturas têm necessidade de todas as culturas" (GLISSANT, 2005, p. 156).

Nesse sentido, as duas perspectivas que conduzem a discussão da relação entre língua e identidade cultural em Glissant, aqui referidas em linguagem experimental como crítica histórica e crítica filosófica, complementam-se e definem um quadro epistemológico estável, onde as noções de alteridade e diversidade alimentam novas reflexões sobre a questão identitária. São, em suma, perspectivas que comportam uma leitura mais precisa da dinâmica intercultural e da multiplicidade de identidades características do cenário moderno, transformando a experiência da diversidade em "uma outra maneira de frequentar este mundo [...]" (GLISSANT, 1993, p. 48).

\footnotetext{
${ }^{22}$ Expressão congênere ao conceito do Todo-mundo, referida em Traité du Tout-monde: "A totalidade-mundo em sua diversidade física e nas representações que ela nos inspira: que nós não saberíamos mais cantar, dizer ou trabalhar à pena a partir de nosso lugar somente, sem prolongar ao imaginário dessa totalidade" (GLISSANT, 1997, p. 176).
} 


\section{Capítulo IV: Cultura crioula e "crioulização"}

\section{Pressupostos}

O conceito de "crioulização" é, a um só tempo, a síntese da diversidade como traço maior das Antilhas e a expressão mais contundente da busca por uma identidade cultural naquele contexto. Não surpreende, portanto, que a análise deste conceito seja tarefa árdua, envolvendo um esforço conjunto de leitura em distintas frentes - a histórica, a antropológica, a linguística, principalmente -, as quais se confundem sem cessar. No percurso reflexivo ora proposto procurar-se-á recuperar a origem primeira do termo, seu sentido mais remoto, sua evolução, discutir sua recriação epistemológica no século XX para servir aos novos movimentos socioculturais que então emergiam no Caribe e, ao cabo, mostrar como a elaboração da noção de "crioulização" revelou-se decisiva para a tomada de consciência de autores e intelectuais de origens variadas e com diferentes biografias para a problemática cultural e identitária na região. Como se há de constatar, a discussão será providencial para que se possa avançar mais um passo pelas sendas do pensamento glissantiano, de modo a verificar sua participação nesse processo e, sobretudo, a presença e as consequências do conceito na obra do autor.

\section{O termo "crioulo"}

O termo crioulo surgiu no século XVI para designar uma proveniência em particular, no caso aquela de pessoas e produtos os mais variados ligados ao Caribe, e somente mais tarde passou a referir-se às línguas híbridas oriundas do contato do francês, do inglês, do holandês, com línguas nativas locais ou importadas (de origem africana). Desde então, têm-se usado expressões como "línguas de contato", "línguas mistas" e outras para indicar o crioulo em suas variadas manifestações diacrônicas e diatópicas, na tentativa de conferir-lhe uma definição, um roteiro de formação e uma especificidade. Mais importante, porém, e passando ao largo de descrições tipológicas mais formais e por vezes vagas, é considerar os elementos que essa noção traz à linguística e à sociolinguística quanto ao debate dos efeitos possíveis do contato entre línguas e culturas diversas para a formação de uma comunidade como a antilhana. 
Uma vez que a tradição historiográfica estabeleceu que estas línguas se configuraram no âmbito da colonização, numa situação comunicacional entre senhores e escravos, acrescido seu caráter exclusivamente oral, discutir a presença do conceito em semelhante quadro sóciohistórico significa tanger ao ponto questões de identidade e representação próximas ou comparáveis àquela relativa à alteridade e diversidade.

Mais do que designar uma língua, o termo crioulo determinava uma distinção de classe e condição social. Nas colônias francesas do Caribe, por exemplo, eram correntes as expressões "Blanc créole" e "Nègre créole", que funcionavam para indicar os descendentes de colonos europeus e os descentes de escravos africanos nascidos nas ilhas, respectivamente. Assim, desde o começo, impõe-se uma espécie de categorização que objetivava diferenciar, no interior da "naturalidade" crioula comum, diferentes extratos étnicos da população. Em paralelo, no entanto, convém ressaltar que já nesta época (séculos XVII-XVIII) o traço de aculturação faziase presente, isto é, havia já um movimento pela integração dos escravos crioulos, aqueles ali nascidos, ao sistema de valores da vida colonial.

Do termo espanhol "criollo", aplicado aos indivíduos nascidos nas ilhas filhos de pais estrangeiros, a noção aos poucos fluiu para o plano linguístico, cobrindo de modo genérico expressões distintas e bastante particulares a depender do contexto em que surgiam. Assim, referiu-se como crioula à língua de base inglesa falada na Jamaica, ao papiamento corrente em Curaçao e à língua de base francesa falada no Haiti e em outras ilhas caribenhas de colonização francesa.

O caso das Antilhas chama a atenção, mais que qualquer outro, pela própria diversidade de línguas ditas crioulas constituídas a partir da base espanhola, portuguesa, francesa e mesmo inglesa, o que está intimamente relacionado aos processos sócio-históricos e políticos marcantes em cada região.

Esta complexa dinâmica linguística responde, enfim, pelo sentido da cultura caribenha, destilado em múltiplas variantes da modalidade oral, desde o vasto cancioneiro local, passando pelo folclore, fábulas e contos, até a poesia. Interessante é notar, nesse sentido, como a especificidade destas línguas oriundas de uma singular situação comunicacional, aparecidas no núcleo de instável conformação étnico-cultural, concorreu para definir ou ao menos sugerir os traços identitários daquela comunidade. 


\section{O particular da situação linguística antilhana}

Para avaliar as implicações do crioulo na elaboração da cultura antilhana deve-se antes esclarecer que a questão linguística ocupa uma das instâncias da experiência da diversidade ali observada, nomeadamente a diglossia.

Termo de raiz grega introduzido no campo da sociolinguística por Charles Ferguson (1959), a diglossia refere-se à situação linguística em que duas línguas coexistem, sendo que o uso de uma está sujeito à condição comunicativa da outra, acrescido o valor de hierarquia que distingue este conceito da noção mais simples de bilinguismo. Está presente nessa definição a ideia de dominação de uma língua A sobre uma língua B, numa dada comunidade e em determinado contexto, como acontece na Martinica entre o francês e o crioulo.

Na seção 70 de Le Discours antillais, nomeada “A linguagem da nação", Glissant observa criticamente esta relação, afirmando que

O particular das Antilhas francófonas é que a língua oficial é uma língua de consumo. A situação que resulta disso é que o locutor está deportado entre e por estes dois impossíveis: o caráter "em suspensão" de uma língua que não serve para produzir nem para criar o que quer que seja (o crioulo), o caráter "irresponsabilizado" de uma língua que não serve senão para consumir (o francês).

Nenhuma consideração sobre as vantagens sociais que beneficiam passivamente os martiniquenses impedirá que se reporte esta situação ao mesmo tempo política, econômica e linguística à condição de um colonizado" (GLISSANT, 1981, p. 357, grifo do autor).

Ora, talvez de forma mais plangente do que qualquer outro aspecto da realidade antilhana, a diglossia expõe a fissura que há entre o plano da dominação (política, econômica, cultural) colonial europeia e o plano social no qual está inserida a sociedade local diacronicamente constituída ${ }^{23}$. O francês, nesse cenário, é uma língua imposta, língua que representa o poderio do colonizador, ao passo que o crioulo é a língua investida das qualidades afetivas que respondem pela memória e pelo sentimento de pertencimento a uma cultura, é a língua que simboliza determinação e independência.

Para Albert Memmi (1967, p. 98) esta é a situação clássica do “drama linguístico” dos povos colonizados ${ }^{24}$, em que se vive o dilema da expressão e da comunicação na língua do antigo opressor ou na língua popular cada vez mais ameaçada pelo avanço maciço daquela ${ }^{25}$.

\footnotetext{
${ }^{23}$ Deriva da observação deste fato a posição crítica de Glissant acerca da diglossia. O autor resume a questão da seguinte forma: "O discurso diglóssico é a medida da vivência alienada" (Glissant, 1981, p. 85).

${ }^{24}$ Memmi refere-se especificamente à realidade do escritor francófono colonial.

25 “O antilhano corre o risco de perder sua identidade, sua cultura, sua história; os meios de assimilação não fizeram que aliená-lo ainda mais. Sua economia é assistida, sua língua, o crioulo, se afrancesa cada vez mais; a
} 
Esta peculiar questão atravessa a literatura antilhana, onde materializa-se sob a forma de uma reflexão sobre a dimensão da escrita, conforme testemunha Patrick Chamoiseau (1997):

\begin{abstract}
A língua francesa batendo as colinas, os canaviais, as ravinas, as usinas. Não podendo nada desertar por vias poéticas, ela se prende sobre alteridades indescritíveis e sobre soluços de crioulo reprimido. Eis-me abandonado. A língua que não sabe o que pôr na boca dos negros-da-terra, e que mal abarca os eventos de seu espírito. A língua, então, que impõe sua ronda secreta, remodela o país, transforma o povo das canas-deaçúcar em camponeses da Europa (CHAMOISEAU, 1997, p. 79).
\end{abstract}

A passagem descreve o estranhamento provocado pela presença do francês como idioma de uma comunidade compósita marcada por traços culturais próprios, onde se impõe artificialmente e de forma incompatível com aquela realidade espacial e humana, conforme bem exprime a sentença "a língua que não sabe o que pôr na boca dos negros-da-terra, e que mal abarca os eventos de seu espírito". Há, ao mesmo tempo, uma denúncia sutil à fixação da língua do colonizador em tal contexto, quando se diz que o francês "transforma o povo das canas-deaçúcar em camponeses da Europa", o que reflete a postura crítica e o empenho que muitos intelectuais da região demonstraram em causa da emancipação política e cultural das Antilhas.

Flagra-se, então, exatamente neste olhar compartilhado por literatos e pensadores, a emergência de um movimento pela afirmação do crioulo como língua nacional, mas não apenas - sobretudo como identidade étnico-cultural.

Na elaboração das identidades, no entanto, o dado linguístico é indissociável do dado cultural, conforme visto no capítulo inicial, sendo a partir da comunhão de ambos que a noção mesma de identidade se constitui. A questão linguística aparece, assim, como uma plataforma inicial por meio da qual se pode acessar o quadro de valores culturais da comunidade caribenha, em cujo seio a língua crioula foi gerada.

\title{
4. "Cultura da sobrevivência"
}

Em meio às vicissitudes do regime colonial, o crioulo surge forçosamente como parte das muitas criações que encerraram aquilo que Jacky Dahomay (2000, p. 101) chama de uma "cultura da sobrevivência"26, um modo precário e provisório encontrado pelos escravos para

autonegação e a imitação do modelo metropolitano se desenvolvem, significando profundamente aviltamento e subserviência" (RADFORD, 1982, p. 26).

${ }^{26}$ A autora, na verdade, retoma aqui a expressão "ato de sobrevivência" definida por Glissant em Poétique de la Relation, modificando-a. 
"reinventar formas simbólicas ou culturais que [lhes permitissem] viver" na ausência de uma "cultura tecida ao longo das épocas e fundada sobre uma tradição imemorial [...]" (DAHOMAY, 2000, p. 101).

Com isso, não apenas do ponto de vista exclusivamente linguístico, mas ainda do ponto de vista antropológico, social, cultural e até mesmo geográfico, o hibridismo é o traço mais notável dentre as idiossincrasias antilhanas e alicerce de toda pesquisa identitária neste "território".

Ora, a questão identitária antilhana, em Glissant, remete às instâncias da experiência da diversidade vivida nas Antilhas, integrando um sistema de análise social altamente produtivo para o autor martiniquense. Este sistema vem a ser a "crioulização", amadurecido ao longo dos trabalhos Introdução a uma poética da diversidade e Traité du Tout-monde como parte de uma nova proposta de apreensão e interpretação da cultura antilhana e também das demais culturas em formação no mundo contemporâneo, que Glissant (1997, p. 37) define da seguinte maneira: “A crioulização é o contato de muitas culturas ou ao menos de muitos elementos de culturas distintas, num endereço do mundo, tendo por resultado um dado novo, totalmente imprevisível em relação à soma ou à simples síntese destes elementos".

O modelo, assim, define o próprio caráter da cultura crioula antilhana, uma cultura de assimilação, sempre aberta à comunicação com outras culturas. Como fica evidente no texto tardio Philosophie de la Relation, a "crioulização" caracteriza-se por sua intensa dinâmica, na qual os elementos culturais e linguísticos não são reduzidos à uma simples "mescla" geral e indistinta, mas mantém suas propriedades e especificidades:

Na crioulização, nenhum dos componentes se dissolve nos outros que seriam
instituídos como mais poderosos e agressivos. Como complemento este paradoxo
impactante: quando a crioulização se cumpre, as línguas crioulas não tendem mais a
desaparecer, elas proliferam sobre e para elas mesmas, na pior condição de uso, não
produtiva, elas confirmam com todos, e mantém suas fulgurâncias, seu imprevisível,
seu impredizível. É abertura e vento.
A crioulização não é esta mescla informe (uniforme) onde cada um perder-se-ia, mas
uma sequência de surpreendentes resoluções, cuja máxima fluída dir-se-ia assim: "Eu
mudo para cambiar com o outro sem me perder todavia, nem me desnaturar".
Precisamos admiti-lo frequentemente, oferecê-lo sempre (GLISSANT, 2009, pp. 65-
66).

A ideia mesma de "crioulização" assume, nesta linha, uma outra dimensão enquanto processo de assimilação pelos negros cativos dos elementos que constituíam o heterogêneo substrato cultural ao qual estavam expostos. A noção de cultura crioula como "cultura da sobrevivência” exige, neste caso, uma aproximação mais acentuada. 
Os elementos característicos desta cultura, então, seriam aqueles já insistentemente apontados pela antropologia: “[...] relações de parentesco e sexualidade, relações com o culto dos mortos, com a religião, constituição da língua crioula, etc.” (DAHOMAY, 2000, p. 102). Especialmente a formação da língua crioula representa um aspecto decisivo para o desenvolvimento da "cultura da sobrevivência" neste contexto, pois seu aparecimento esteve associado a uma necessidade comunicacional básica entre membros de comunidades linguísticas distintas subitamente postos em contato, conforme visto em definição anterior. $\mathrm{O}$ que merece ser recobrado, porém, é a situação comunicacional específica da língua crioula e o espaço comum em que se realizava.

Para isso, cumpre considerar uma expressão marcante usada pelos falantes nativos ao se referirem ao crioulo: "parole de nuit" ou "fala da noite", porque era justamente à noite, à roda de uma fogueira ou ao abrigo das feitorias, após a árdua jornada de trabalho, que os escravos se reuniam para trocar experiências e falar de assuntos diversos, valendo-se assim da língua híbrida ${ }^{27}$. Conforme sustenta Ralph Ludwig (1994):

A noite [...] foi sempre o lugar da fala crioula. É ao crepúsculo que o contador crioulo reunia seu auditório. É uma vez caída a noite que se conta a vida dos ancestrais às crianças, e é aí ainda que se festeja sua morte ao curso das vigílias. A noite é o universo do lazer, do prazer sensual e da insubmissão frente às restrições do dia (LUDWIG, 1994, p. 18).

Ora, aí está esboçada a circunstância básica a partir da qual o crioulo internalizou-se como língua afetiva para seus usuários, tornando-se mais tarde uma língua de circulação "popular", propriamente dita. Por outro lado, pode-se dizer que o plano espacial de referências comuns ao escravo em tais condições é o universo da plantação ${ }^{28}$, isto é, o espaço das vastas extensões de terras cultivadas onde se empregava a mão-de-obra negra, base do sistema agrícola colonial $^{29}$.

$\mathrm{Na}$ verdade, o desenvolvimento da cultura crioula nas Antilhas se justifica, por assim dizer, pela associação ou dependência da comunidade local em relação ao modelo econômico

\footnotetext{
${ }^{27}$ A expressão é de Bertène Juminer (1994, pp. 147-148, grifo do autor), que a explica da seguinte maneira: "a fala da noite, assim nomeada porque intervindo ritualmente depois do pôr do sol e germinando dos sedimentos de uma memória coletiva. Corolário de uma intimidade natural com a grande idade, ela informava e formava, confortando uma certeza identitária."

${ }^{28} \mathrm{O}$ termo plantation (plantação), em francês e inglês, é específico para um modelo de cultivo agrícola de produtos tropicais que vigorou nas colônias do Novo Mundo. Segundo Glissant (1990, p. 89): "A Plantação é um dos ventres do mundo, não o único, um dentre tantos outros, mas que apresenta a vantagem de que se possa perscrutá-lo com a maior precisão possível".

29 "No universo mudo da Plantação, a expressão oral, a única possível para os escravos, se organiza de maneira não contínua. $\mathrm{O}$ aparecimento de contos, provérbios, ditados, canções, tanto no mundo crioulófono quanto alhures, está marcada pelo signo deste descontínuo" (GLISSANT, 1990, p. 82).
} 
metropolitano centrado fundamentalmente na monocultura da cana-de-açúcar, o que configura logo à primeira-mão o ambiente onde se nutriu esta cultura.

Neste ponto, há que se reconhecer, as noções de língua e cultura parecem confundirse. E não é fortuita essa impressão, uma vez que observar o processo de formação cultural das Antilhas é como acompanhar em tempo real o próprio nascimento desses conceitos e sua disposição numa dada estrutura social.

A emergência da língua crioula foi acompanhada paralelamente pelo surgimento de um modus vivendi característico da comunidade que começava a se formar, ou seja, à medida em que a língua ganhava substância e se assentava como código primário da comunicação oral certas práticas, hábitos e costumes partilhados pelos seus usuários começavam a dar feições particulares ao grupo que integravam. Conforme observa Bertène Juminer (1994):

Tudo bem considerado, a transferência histórica dos africanos para a imensa tortura americana, ainda mais que um ultraje à sua integridade física e moral, foi um grave atentado à sua cultura, isto é, à sua memória e à sua fala. Para eles, se lembrar, falar e criar, apesar do exílio e da degradação, tornavam-se tantos atos de resistência, logo de salvaguarda. Cativos perdidos nas trevas do Novo-Mundo, eles apreendiam a essência e a existência através de uma outra noite fugidia e densa, cuja exploração não podia advir senão fora de sempiternos trabalhos forçados sob as línguas de fogo do sol, este inimigo mortal cúmplice de olhos dominadores e de braços assassinos (JUMINER, 1994, p. 131, grifo do autor).

Segundo esta concepção da elaboração primeira da língua/cultura antilhana originaram-se os alicerces da "crioulização", perspectiva inaugurada por Glissant para tratar não apenas da questão identitária naquele contexto, como também das relações entre línguas, culturas e identidades no mundo contemporâneo. É como se a pesquisa da "crioulização" no Caribe, seu berço histórico, fosse uma abertura para a pesquisa do fenômeno em crescente expansão no panorama global, permitindo uma nova avaliação das fronteiras das identidades na modernidade:

Eu supunha que uma língua crioula, não um dialeto nem um patoá, nem a deformação genial e agressiva de uma língua dominante, é a resultante imprevisível, impredizível e fulgurante, num tempo e num lugar, do encontro de dados linguísticos (léxicos, sintaxes e modos de falar, absolutamente heterogêneos, com resultantes inesperadas: que a crioulização das culturas tem estes diversos caracteres e não uma essência de uma natureza crioula. Quando os países se crioulizam, eles não se tornam crioulos à maneira dos habitantes das ilhas antilhanas, por exemplo, eles entram no imprevisto consentido de suas diversidades, às vezes dramaticamente (GLISSANT, 2009, p. 65). 


\section{Identidade crioula}

Do ponto de vista da busca identitária, a língua/cultura antilhana foi explorada continuamente no último século. A procura das raízes crioulas levou à ênfase literária em determinados elementos e imagens que configuram a vasta tradição popular local, os quais integram o imaginário comum e correspondem a modelos de referência representativos de uma ideia de pertencimento partilhada pelos membros da comunidade. Por um lado, isso pode ser observado na própria tradição oral crioula, através das canções de trabalho, dos cânticos rituais, dos provérbios, das lendas e fábulas que compõem o patrimônio ancestral antilhano; e por outro, pela atenção a figuras como a do feiticeiro e do marron, o escravo fugido, ambas muito marcantes quanto àquilo que sugerem em termos de práticas religiosas e mediação espiritual, no primeiro caso, e de resistência ao jugo do colonizador e bravura, no segundo. Daí a presença constante de aspectos dessa natureza na ficção antilhana, como em Glissant e Maryse Condé, por exemplo, onde testemunham o esforço pela valorização da herança simbólica de seus antepassados e pela descoberta de uma identidade pulsante por parte destes autores.

A "crioulização" é a síntese da diversidade linguística, étnica, cultural e até mesmo geográfica do Caribe - espaço de encontros, câmbios e diálogos interculturais. Assim, o conceito exprime a ideia primeira de que as Antilhas seriam uma espécie de anteporta para a multiplicidade que caracteriza as relações culturais ao redor do mundo contemporâneo, simultaneamente um resumo e uma introdução à diversidade presente nas diferentes esferas de contato humano.

A “crioulização", enquanto processo gerador da própria cultura antilhana, passa a presidir, segundo Glissant, a elaboração das culturas na modernidade: "Eu chamo de crioulização o encontro, a interferência, o choque, as harmonias e desarmonias entre culturas na totalidade realizada do mundo-terra" (GLISSANT, 1997, p. 194). Sendo assim, suas principais características seriam:

\footnotetext{
- a rapidez fulminante das interações colocadas em obra;

- a "consciência da consciência" que temos;

- a intervalorização que daí provém e que torna necessário que cada um reavalie para si os componentes postos em contato (a crioulização não supõe uma hierarquia de valores);

- a impredizibilidade dos resultantes (a crioulização não se limita a uma mestiçagem, cujas sínteses poderiam ser previstas) (GLISSANT, 1997, p. 194).
}

O autor não propõe apenas o resgate de uma identidade antilhana subjacente ao jugo colonial, mas investe em um modelo poético-filosófico que, partindo da realidade caribenha, 
abrange toda a rede de culturas e de conhecimento que se sobrepõe a quaisquer fronteiras políticas ou ideológicas. Esta é, enfim, a decisiva conquista do pensamento glissantiano para os novos territórios do saber hoje em formação, quando se torna cada vez mais urgente falar e escrever "na presença" de todas as línguas e culturas (GLISSANT, 2005, p. 49).

O estudo da questão identitária antilhana em Glissant revela, desse modo, outros modos de se perceber noções como diglossia e diversidade cultural, porque mostra que o entrecruzamento de línguas e culturas, longe de ser uma abstração teórica, é um fato no cenário globalizado da atualidade. A “crioulização" em curso na comunidade antilhana pelos últimos quatro séculos é curiosamente revista pelo escritor como um fenômeno atual capaz de responder pelos trânsitos e trocas em fluxo continuado pelo mundo, ou seja, aquilo que se considerava como aspecto restrito e endêmico característico de uma determinada comunidade revela-se enquanto mensagem da "abertura e da partilha" intercultural (GLISSANT, 1997, p. 231).

A “crioulização", por isso, emerge como canal de passagem e travessia entre línguas, culturas e lugares, descrevendo um "trajeto de errância, do lugar à totalidade, e inversamente" (GLISSANT, 1997, p. 183) que perpassa as identidades em múltiplas formas ou perspectivas através do tempo e do espaço. 


\section{Capítulo V: Poética do Diverso e identidades plurais}

\section{Releitura do mundo}

No horizonte do pensamento glissantiano, a "crioulização" representa um novo modo de perceber o conceito de identidade no mundo moderno - não mais como algo fixo e estanque, mas como noção aberta e em constante transformação. Na verdade, ao defender uma "multirelação" entre culturas e identidades e ao insistir em uma concepção poética baseada na diversidade, o autor sinaliza para uma interpretação original dos contatos humanos sob o signo dos fenômenos socioculturais que caracterizam o cenário contemporâneo, tais como o plurilinguismo, os fluxos transnacionais e a dinamização dos meios de informação.

Daí a afirmação da parte de Glissant (1997, p. 194) de que "hoje o mundo inteiro se criouliza e arquipeliza", a qual vem confirmar uma tendência geral de abertura à diversidade e ao contato dinâmico entre povos e culturas no sentido da construção de novas identidades, movimento contingente descrito por James Clifford (1997) através da ideia das "traveling cultures" e também por Zygmunt Bauman (2000) a partir da imagem da "modernidade líquida".

O veículo conceitual deste novo olhar é o Diverso, que vem se contrapor ao Mesmo generalizante, o qual está relacionado ao primado do eu na tradição filosófica ocidental, afeita à centralização e baseada na busca pelo chamado absoluto ou universal totalitário. Glissant, por seu turno, contesta tal percepção da realidade desde os primeiros ensaios que publica, ainda na década de 1950, propondo uma interpretação aberta das identidades culturais, vistas agora como parte de um processo em permanente devir que tem lugar nas vias de contato entre culturas e comunidades diversas.

Procede deste exame a emergência da noção de identidades "multiformes", surgidas de confluências étnicas e linguísticas em diferentes ambientes e situações relacionais e comunicacionais, conforme os próprios caminhos de construção da cultura crioula antilhana levavam a supor quando esta se originou, isto é, pela hibridização de elementos culturais de variadas proveniências.

Assim, a apreensão dos novos conceitos de identidade deflagrados na contemporaneidade leva a um proporcional entendimento dos meios de aproximação entre as sociedades, quando são imprevisíveis as trocas e convergências ou os conflitos e tensões 
produzidos no bojo da Relação - uma vez admitida a presença incontornável deste princípio na esfera das ações humanas.

Para Glissant este cenário pode ser bem ilustrado pela emergência do Diverso, "que 'passa' pela totalidade dos povos e das comunidades" (GLISSANT, 1981, p. 191) e vem substituir o Mesmo como parte de um processo de transformação histórica e de renovação de perspectivas, onde a multiplicidade convida à partilha e ao diálogo. O Diverso enseja uma temporalidade própria e uma nova força poética que acompanha este movimento de passagem da civilização.

Diva Damato (1996), sob esta luz, interpreta o conceito glissantiano como meio de transição, como ponte entre a percepção da diversidade e sua efetiva experiência:

O tempo do Diverso corresponde à poética da Relação: o Um é substituído pelo plural, o absoluto, pelo relativo, a hierarquia, pela relação igualitária, a História, pelas histórias.

O Diverso não significa a eliminação do Um mas o fim de sua dominação. Os povos emergentes ao contestarem a predominância do Ocidente integram-no no mundo, forçam-no a relativizar-se.

O Diverso é plural. Assistiríamos então à substituição do eu pelo nós, mas um nós que não esmague nem dilua o eu, onde o nós implique o eu. O Diverso não é um conjunto de indivíduos mas um feixe de relações (DAMATO, 1996, p. 185, grifo do autor).

O Diverso parte, assim, da recusa dos termos homogeneizantes e generalizantes que acompanham as vias da história ocidental e processos como o colonialismo e o imperialismo. Ao se questionar a dominação do eu, põe-se em jogo a própria centralização étnica, linguística, política e filosófica europeia e aquilo que ela representa, ou seja, a oposição à diferença, a sagração do mito da origem única, a ideia mesma de permanência e fixidez. $\mathrm{O}$ eu equivale, nesse sentido, ao Mesmo e define a "ideologia do universal" que as grandes nações hegemônicas do velho continente procuraram a todo custo implantar em suas dependências coloniais:

Se não retemos os aspectos fundamentais desta passagem (do Mesmo ao Diverso) que são a luta política, a sobrevivência econômica, e se não compatibilizamos os episódios centrais (massacre dos povos, emigrações, deportações, talvez este mais grave dos avatares que é a assimilação), e que tomemos uma vista global, nos apercebemos que o Mesmo, imaginário do Ocidente, conheceu um enriquecimento progressivo, um estabelecimento harmonioso no mundo, tais que ele pôde "passar", quase sem ter que se admitir, da ideia platônica ao foguete lunar. Os conflitos nacionais marcaram do interior o impulso do Ocidente acerca de uma única ambição, que era impor ao mundo como valor universal o conjunto de seus valores particulares (GLISSANT, 1981, p. 191, grifo nosso).

A passagem do Mesmo ao Diverso, como se vê, não se dá de forma tranquila, mas envolve uma série de tensões e lutas em torno do contraditório e do não-solucionado. Trata-se 
de um movimento deflagrado no contexto da chamada "aceleração da história", fenômeno que "provém da saturação do Mesmo, como uma água que transborda de seu recipiente, e por todo lado 'desbloqueou' a exigência do Diverso” (GLISSANT, 1981, p. 191).

E são fortes as reverberações deste processo na atualidade, quando conflitos nas antigas periferias coloniais levam a diásporas forçadas e ao aumento do fluxo migratório internacional, cobrando novas posturas diante da diversidade cultural, linguística e religiosa, e da urgência colocada pelos contados entre diferentes comunidades ${ }^{30}$.

Para o pensador martiniquense o Diverso estabelece outros modos de aproximação entre os povos na "totalidade-mundo", pois está além das fronteiras entre dominadores e dominados, entre metrópoles e colônias, promovendo a igualdade relacional em lugar do absoluto arbitrário:

O Diverso, que não é o caótico nem o estéril, significa o esforço do espírito humano em direção a uma relação transversal, sem transcendência universalista. O Diverso tem necessidade da presença dos povos, não mais como objeto a sublimar, mas como projeto a ser posto em relação. O Mesmo requer o Ser, o Diverso estabelece a Relação (GLISSANT, 1981, p. 190).

Glissant problematiza então as noções de unidade e homogeneidade, mostrando, por meio do Diverso, que as novas dinâmicas culturais exigem a participação de um nós e a comunhão das singularidades em uma fulgurante pluralidade, a qual, no entanto, não dissolve ou apaga as idiossincrasias dos elementos individuais, de acordo com a própria "alquimia da crioulização", que é "processo e não fixidez” (GLISSANT, 2009, p. 64).

A poética do Diverso é um desdobramento ou uma das faces múltiplas da Relação que nasce, assim como esta, a partir da proposta do Discours antillais. É outro esforço de leitura e apreensão das novas identidades culturais apoiado em pares dialéticos (raiz x rizoma; eu x nós; diglossia x multilinguismo), pelo qual se procura interpretar os modos variados de participação da sociedade no movimento relacional, bem como os valores aí envolvidos.

A presença deste conceito em Glissant também diz bastante sobre sua percepção acerca das imprevisíveis consequências do encontro de culturas, geralmente envolvendo poder político

\footnotetext{
${ }^{30}$ Valeria, nesse sentido, a lembrança das inéditas e profundas transformações políticas e sociais que advieram a partir da chamada Primavera Árabe (2011) nos países islâmicos do norte da África e também da grave crise humanitária no Oriente-Médio, particularmente na Síria. Os desdobramentos destes dois importantes movimentos na contemporaneidade incluem o êxodo em massa de refugiados em direção à Europa e a exigência, desde então, de novos posicionamentos governamentais e de novos modos de se lidar com a diversidade em tal contexto. Conforme refletia Glissant e tem sido possível acompanhar, o encontro de culturas envolve necessariamente tensões, conflitos e choques, antes que se possa chegar à partilha e ao diálogo.
} 
e econômico. A ação expansionista europeia foi acompanhada por um discurso da "diferença contida dentro da fantasia da origem e da identidade” (BHABHA, 1998, p. 106), cuja articulação se deu através do Mesmo, tornado vetor de um "modo de representação da alteridade" (BHABHA, 1998, p. 107, grifo do autor) onde os povos dominados são introduzidos como "inferiores" e incapazes de se autogovernarem. Nesse cenário, Glissant interpreta o Diverso como uma resposta social à hegemonia do Mesmo, isto é, como resultado dos movimentos de liberação frente ao jugo do colonizador.

Se o discurso de dominação estimula a diferença entre dominadores e dominados, ao mesmo tempo em que cria para estes últimos um "espaço comum” que suprime particularidades étnicas, culturais e históricas ${ }^{31}$, o novo discurso da diversidade propõe a coexistência e o compartilhamento. Daí a afirmação: "O Mesmo é a diferença sublimada; o Diverso é a diferença consentida" (GLISSANT, 1981, p. 191).

E vale ressaltar que aqui a ideia de diferença não corresponde exatamente à voga do chamado "direito à diferença", pois, como explica o autor martiniquense em nota a esta derradeira referência ${ }^{32}$, tal proposição implicaria no estabelecimento de "uma hierarquia de naturezas", quando, ao contrário, deve-se compreender que "o Diverso introduz a Relação: é a implicação moderna das culturas, em suas errâncias, sua reivindicação 'estrutural' de uma igualdade sem reserva" (GLISSANT, 1981, p. 191).

\section{Experiência antilhana e fundamentos poéticos}

Ora, para perceber como se estrutura a poética glissantiana do Diverso e o modo pelo qual está associada à visão das identidades plurais, urge retomar, ainda uma vez, certos aspectos latentes da realidade antilhana e da experiência da diversidade ali observada. Por oportuno, seja vista a seguinte declaração do autor em entrevista concedida à Philippe Artières (2003), na qual refere-se às três dimensões que lhe parecem essenciais na orientação da poesia:

- A primeira dimensão é aquela da paisagem. Ela é, claramente, capital, porque, nesta relação das culturas do mundo, e em particular nesta relação entre colonizados e

\footnotetext{
${ }^{31}$ Este pensamento é expresso por Homi Bhabha (1998, p. 111), que considera o discurso colonial como um "aparato de poder" que "se apoia no reconhecimento e repúdio de diferenças raciais/culturais/históricas" acerca dos povos dominados. Segundo o autor: "Sua função estratégica é a criação de um espaço para 'povos sujeitos' através da produção de conhecimentos em termos dos quais se exerce vigilância e se estimula uma forma complexa de prazer/desprazer. [...] O objetivo do discurso colonial é apresentar o colonizado como uma população de tipos degenerados com base na origem racial de modo a justificar a conquista e estabelecer sistemas de administração" (BHABHA, 1998, p. 111).

${ }^{32}$ Cf. nota 1 da página indicada.
} 
colonizadores, o espaço é um dos elementos fundamentais. Quando não memorizamos, quando não frequentamos livremente seu espaço, que entre a paisagem e você existe toda uma série de barreiras que são as da depossessão e da exploração, a relação com a paisagem é evidentemente limitada e garroteada. Por conseguinte, liberar a relação com a paisagem pelo ato poético, pelo dizer poético, é fazer obra de liberação.

- A segunda dimensão é aquela do tempo. Retornamos aqui, de chofre, aos contatos das culturas do mundo entre elas, a um fenômeno fundamental nos colonialismos: o colonizador priva o mais das vezes o colonizado de sua memória histórica, da capacidade de compreender os eventos e suas causas. Por conseguinte, a relação com o tempo pelo viés da relação com a história, com a memória histórica, torna-se fundamental do ponto de vista político e poético. Por exemplo, para nós antilhanos, que sofremos uma forma bem particular de colonização cuja expressão última e maior foi a assimilação à cultura francesa, à história da França, etc., a memória histórica que foi aplainada, usada, corroída pelo ato colonizador se apresenta como um caos. Não há linearidade temporal na memória histórica do colonizado mas uma espécie de caos no qual ele cai e rola; eis por que eu digo sempre que "nós precipitamos as rochas do tempo". Em nossa memória coletiva, um evento pode se desdobrar hoje e ser imediatamente rejeitado em nosso inconsciente coletivo, como ele pode ter se passado a quatro séculos e ressurgir com uma luz e uma força extraordinárias. [...]

- A terceira dimensão é evidentemente tão importante quanto, a partir do momento em que concebemos o processo poético e político nesta espécie de globalidade que é o mundo atual tal como ele nos foi legado pelas histórias dos colonizadores: é aquela da linguagem. Pois, ou bem as linguagens dos povos colonizados foram restringidas a um uso derrisório - não um uso de conhecimento -, ou bem ela se formou de linguagens novas que chamamos de linguagens crioulas. Nós levamos muito tempo para compreender que essas linguagens tinham um interesse fundamental, pois elas eram "linguagens de linguagens" e não linguagens originais, e que essas linguagens pressagiavam o que se passa na hora atual onde as línguas do mundo se crioulizam mutuamente.

Se não integramos em profundidade estas três dimensões, não compreendemos nem esses abalos que encontramos nas poéticas modernas, nem essas impossibilidades contra as quais colidem as políticas modernas (ARTIÈRES, 2003, pp. 11-12).

Este excerto exige, sem dúvida, uma análise pormenorizada a fim de melhor interpretar os pontos de articulação entre a noção de poesia defendida pelo autor como uma outra maneira de conceber as relações interpessoais e a estética do Diverso, que vem a constituir uma nova proposta de leitura dos fenômenos socioculturais na modernidade.

Assim sendo, que se possa agora passar em exame cada uma das dimensões que orientam o pensamento poético de Glissant.

Paisagem: é a dimensão que corresponde à poética do espaço, cujo valor encontra-se vinculado à própria dinâmica geográfica antilhana, também representada pelo escritor através da metáfora do arquipélago. Trata-se de uma potência, que é o lugar, o lugar (re)conquistado e aberto para o imaginário do mundo. As Antilhas são, deve-se lembrar, um conjunto irradiado de ilhas, as Ilhas do Vento, descritas por um vasto arco fractal, um espaço de entremeio da unidade para a totalidade, simbolizando e antecipando a diversidade que para além se estende e cada vez mais: 
O imaginário do meu lugar está religado à realidade imaginável dos lugares do mundo, e inversamente. $\mathrm{O}$ arquipélago é esta realidade fonte, não única, de onde são secretados estes imaginários: o esquema do pertencimento e da relação, ao mesmo tempo. $\mathrm{O}$ arquipélago é difratado, nós insistiremos até repetir, à maneira desses praticantes das ciências do caos, que ele é fractal (nós damos sentidos não autorizados a esse termo), necessário em sua totalidade, frágil ou eventual em sua unidade, passando e ficando, é um estado do mundo (GLISSANT, 2009, p. 47).

Tempo: é talvez a mais complexa das dimensões tratadas, pois se faz totalmente abstrato e impalpável, enquanto que a paisagem e a linguagem desfrutam de materialidade expressiva. O tempo relaciona-se à memória coletiva e ao sentimento de pertencimento, avatares da identidade cultural solapados pela ação colonial, a qual visava justamente impedir que se sedimentasse no imaginário dos povos dominados o valor da consciência histórica e social. Daí o tempo estar implicado na questão identitária antilhana e revelar-se tão incerto naquele contexto, sendo sua reintegração e restabelecimento parte do empenho poético do escritor: "Porque o tempo antilhano foi estabilizado no nada de uma não-história imposta, o escritor deve contribuir para restabelecer sua cronologia atormentada, isto é, para desvelar a vivacidade fecunda de uma dialética refeita entre natureza e cultura antilhanas" (GLISSANT, 1981, p. 133).

Linguagem: veículo de expressão poética, é vista como um princípio e uma construção que enseja a pluralidade. Uma das consequências do colonialismo foi o surgimento de línguas híbridas a partir de determinadas situações comunicacionais entre membros de comunidades linguísticas distintas, a exemplo do crioulo de base francesa falado na Martinica. Na realidade do mundo globalizado, Glissant entende que o processo de "crioulização" das línguas em permanente contato é um dado posto irreversível, assim como a progressiva "crioulização" cultural: "A linguagem de si e a linguagem do distante se interrogam (é a intimidade cósmica), a linguagem de si em direção à linguagem do outro se adivinha (em tentação da diversidade) [...]" (GLISSANT, 2009, p. 105).

O pensador martiniquense fala, portanto, da relação entre povos, línguas e culturas na "totalidade-mundo", refletindo acerca das possibilidades oferecidas pelo movimento sempre latente do Diverso. Com efeito, a poética da diversidade ilumina novos modos de assumir as identidades que surgem (e também aquelas que se transformam através do tempo) a partir das várias dinâmicas culturais e dos diferentes processos em devir. Deixa-se para trás, nesse sistema relacional do Diverso, as inadequadas noções de raiz e origem única, que são substituídas pela ideia de identidades rizomáticas, isto é, identidades que não pressupõem hierarquias ou supremacias, mas coexistência e mutualidade. 


\section{Rizoma e pluralidade}

Quanto à essa percepção específica das identidades, cumpre retomar o conceito de rizoma, desenvolvido por Deleuze e Guattari (1995), que abre discussão filosófica sobre formas epistemológicas não lineares. O rizoma opõe-se à raiz: trata-se de uma configuração multidirecional, de uma abertura que explora dimensões moventes, como desdobramento de feixes que se entrelaçam e multiplicam ao infinito. O paradigma formal, nesse caso, provém da morfologia vegetal, do sistema de crescimento de certas plantas que se desenvolvem em complexos aglutinantes, mas encontra correspondências igualmente na paisagem antilhana, com a mangrove ou manguezal, tipo de floresta das regiões tropicais caracterizado por árvores de raízes aéreas que, confundindo-se com galhos e ramos em profusão, formam um emaranhado vertiginoso.

O traço de difusão ampla e em todas as direções é fundamental, firmando o contraponto entre o princípio rizomático e a ideia de raiz, vinculada à verticalidade e linearidade: "um rizoma pode ser conectado a qualquer outro e deve sê-lo. É muito diferente da árvore ou da raiz que fixam um ponto, uma ordem” (DELEUZE; GUATTARI, 1995, p. 15). Diz Glissant em Poétique de la Relation:

Gilles Deleuze e Félix Guattari criticaram as noções de raiz e talvez de enraizamento. A raiz é única, é uma base que toma tudo sobre ela e mata em torno; eles lhe opõem o rizoma, que é uma base desmultiplicada, estendida em rede na terra ou no ar, sem que nenhuma base intervenha como predador irremediável. A noção de rizoma manteria então o fato do enraizamento, mas recusa a ideia de uma raiz totalitária. $\mathrm{O}$ pensamento do rizoma estaria no princípio daquilo que chamo uma poética da Relação, segundo a qual toda identidade se estende num reporte ao Outro (GLISSANT, 1990, p. 23).

Assim, por meio do Diverso e da perspectiva de "identidades plurais" descortinada nessa poética, o autor chega a contestar consistentemente aquela “concepção sublime e mortal que os povos da Europa e as culturas ocidentais veicularam no mundo; ou seja, toda identidade é uma identidade de raiz única e exclui o outro" (GLISSANT, 2005, p. 27). Segundo Glissant, esta visão limitada legada pela tradição ocidental "se opõe à noção hoje 'real', nas culturas compósitas, da identidade como fator e como resultado de uma crioulização, ou seja, da identidade como rizoma, da identidade não mais como raiz única mas como raiz indo ao encontro de outras raízes" (GLISSANT, 2005, p. 27).

Significa dizer, em outras palavras, que na modernidade os preceitos identitários baseados na unidade, na permanência e no mito da origem já não têm razão de ser, pois as 
relações interculturais renovaram-se e expandiram-se na variação, na "crioulização" e na diversidade.

O gesto de interlocução linguística e cultural efetiva-se então, e a interdependência torna-se signo da mudança anunciada:

Enquanto não tivermos aceitado a ideia - não apenas através do conceito, mas graças ao imaginário das humanidades - de que a totalidade-mundo é um rizoma no qual todos têm necessidade de todos, é evidente que haverá culturas que estarão ameaçadas. Não será nem através da força, nem através do conceito que protegeremos essas culturas, mas através do imaginário da totalidade-mundo, isto é, através da necessidade vivida do seguinte fato: todas as culturas têm necessidade de todas as culturas (GLISSANT, 2005, p. 156).

O Diverso é comunhão na pluralidade, é presença na contingência das identidades que variam e se constroem, e é através dele que se afirma a potência do imaginário das culturas em sua dinâmica e fulguração. 


\section{Capítulo VI: Ação política e itinerário filosófico}

\section{Formação e afirmação autoral}

Concebido na mesma época em que Édouard Glissant atuava junto à Unesco, Le Discours antillais reverbera as mais significativas reivindicações políticas do autor para as Antilhas, ao mesmo tempo em que estabelece os fundamentos de uma nova perspectiva filosófica acerca das noções de cultura e identidade. Sua estrutura, sua organização, o conteúdo de seus tópicos e seções, tudo enfim, nesta obra, deixa ver a intenção de um projeto de independência das ilhas caribenhas, senão ao menos de afirmação de sua autonomia numa América livre.

Daí a espécie de revisão da história, da formação étnica e social, da língua e da cultura antilhanas levada a cabo por Glissant ao longo de um surpreendente percurso de reflexões, contestações e proposições que culmina no gesto de abertura à comunhão e ao diálogo sob os auspícios da Relação.

O desempenho junto ao organismo internacional, por isso, merece destaque, uma vez que remete ao envolvimento, desde há muito consolidado, do autor em causas sociais e na luta pela liberação de antigos territórios sob tutela francesa. Na medida em que esta ação se reflete na construção da obra poética-crítica-filosófica, justifica-se a sondagem do ativismo de Glissant e do papel que assumiu daí então para a orientação intelectual dos jovens autores da nova literatura antilhana, pois é notável que a publicação de Le Discours antillais tenha representado tanto um divisor de águas na obra do pensador martiniquense, quanto no alcance e projeção de suas propostas para além das comuns fronteiras ideológicas.

Porque a dominação política interfere diretamente na relação do homem com a história, com a língua e a paisagem locais, mais intensa é a demanda de Glissant pela efetiva legitimação de sua posição de escritor e mais agudo o esforço que despende para conquistar o discurso antilhano ou, recuperando as palavras de Dominique Chancé (2000, p. 136), para "fundar a legitimidade do escrito".

A configuração do pensamento glissantiano, ela mesma, ocorre em um momento decisivo daquilo que poderia ser chamado de reorganização discursiva das ciências sociais, quando a sociologia aplicada ao estudo dos povos e culturas de ultramar principiou a separar- 
se da episteme etnológica colonial, anunciando um devir de emancipação com os trabalhos de Claude Lévi-Strauss e Michel Leiris, entre outros.

Há que se destacar ainda a inauguração de um novo capítulo na pesquisa identitária antilhana graças ao aparecimento dos textos Discours sur le colonialisme (1950), de Aimé Césaire, e o célebre Pele negra, máscaras brancas (1952), de Fanon, ambos de forte inspiração sobre o autor, que passou a partir daí a nutrir-se destas importantes referências e aportes teóricos na busca pela formulação de uma nova ideia de identidade e ser no mundo antilhano.

As transformações no cenário político no período do pós-guerra, com a desagregação do domínio colonial europeu e com o florescimento de movimentos independentistas em várias partes do mundo, também contribuíram para a tomada de consciência de Glissant acerca da premente necessidade de mobilizar esforços pela autonomia das Antilhas, o que dará ensejo à formalização de todo um discurso filosófico sobre o dever do escritor de restituir à comunidade despojada de história e de memória coletiva os subsídios para a (re)construção de seu imaginário.

No sentido de levar a efeito este intento, pavimentando o caminho que conduz à identidade e à consciência nacional, o autor idealizou o Institut Martiniquais d'Études (I.M.E) ${ }^{33}$ e a revista $A \operatorname{coma}^{34}$, iniciativas voltadas à divulgação científica e artística e à conexão da rede local de intelectuais, além de ter investido, em seus próprios trabalhos, em uma análise cada vez mais aprofundada do estado de dependência antilhana e de suas consequências.

$\mathrm{Na}$ verdade, este inconformismo com a dominação e todas as reações daí derivadas convergem para um mesmo ponto, o qual corresponde ao empenho do autor em criar um lugar do saber caracteristicamente antilhano, à concentração na "elaboração de um saber e de um discurso sobre as Antilhas" (FONKOUA, 2002, pp. 61-62).

Com esta postura, com o caráter detido na absorção de conhecimentos diversos e, finalmente, com a tendência latente ao engajamento sociopolítico, Glissant parece representar bem a "figura de intelectual total, pensador escritor, romancista metafísico e artista filósofo que engaja nas lutas políticas do momento todas essas autoridades e competências reunidas em sua pessoa" (BOURDIEU, 1992, pp. 344-345, grifo do autor). Obviamente, é inevitável a lembrança daquele que concebeu e encarnou esta figura complexa de intelectual total, teórico

\footnotetext{
${ }^{33}$ Centro de saber e formação fundado pelo escritor em 1967 com a participação de um grupo de intelectuais e pesquisadores antilhanos.

${ }^{34}$ Publicação centrada na área das ciências humanas lançada em 1971 e encerrada em 1973.
} 
da liberdade e do engajamento, Jean-Paul Sartre, cujos trabalhos influenciaram toda uma geração, aí incluído Glissant.

Há, com efeito, uma espécie de teia de relações ligando o ativismo político de pensadores e literatos como Sartre e Albert Camus, que atuavam diretamente no centro propulsor das ideias, e autores como Édouard Glissant, que se mobilizavam em regiões periféricas do mundo, com os mesmos objetivos: a contestação do poder constituído, o empenho na luta autonomista das colônias, a procura por novos espaços para a literatura, etc.

A formação glissantiana está, por conseguinte, fundamentada em linhas gerais das ciências humanas, onde o autor encontra sua voz de autoridade, a legitimação para a ação política que exerce e para as propostas que traz em seus estudos. Etnologia, antropologia, sociologia, linguística... - eis alguns dos principais fluxos que alimentam o caudal de reflexões e investigações do pensador martiniquense, definindo um saber filosófico concentrado que lhe permite "importar em cada um dos domínios a totalidade do capital técnico e simbólico adquirido nos outros" (BOURDIEU, 1992, p. 346).

\section{A etapa filosófica da "formação de pensamento"}

O estudo da filosofia, para Glissant, é uma prerrogativa para a exploração dos demais campos de conhecimento no universo das humanidades, pois significa o preparo de um substrato teórico-epistemológico essencial ao assentamento de quaisquer núcleos reflexivos. Como intelectual engajado, à maneira de Sartre, Glissant tem a preocupação de aliar ao debate sociopolítico um lastro filosófico consistente, base fundamental de sua poética e de seu projeto literário.

Conforme visto, Glissant buscou moldar-se de acordo com as necessidades de seu meio, investindo-se no papel de intelectual total para legitimar sua condição de pensador independente em um "país dominado", situação esta que ilustra o drama de todos os escritores colonizados, tendo em vista o propósito maior de restituir ou de proporcionar à sua comunidade os meios de acesso à sua identidade cultural. 
A ação do autor, sugere Crosta (1991), seja ao lado dos independentistas argelinos, seja no Front Antillo-Guyanais ${ }^{35}$, é indicação máxima deste ideal:

A tomada de posição de Glissant frente à formação identitária dos indivíduos e das
coletividades em situação colonial ou departamental, nos revela a não-conformidade
do autor em relação aos limites, às definições, às prescrições dos diversos discursos
do saber, os quais camuflam ou salvaguardam os interesses (políticos, econômicos,
sociais...) de forças políticas em conflito. Esta tomada de posição advém de suas
reflexões sobre a experiência histórica do povo antilhano. Em particular, Glissant
ataca o discurso daqueles que, sob pretexto de "civilizar os primitivos" ou de
"cristianizar os pagãos", legitimaram a sujeição, senão a aniquilação dos povos de
origem africana (CROSTA, 1991, pp. 09-10).

A instauração de um discurso antilhano livre tem, portanto, a qualidade de estabelecer um contraponto em relação aos vários discursos dominantes, uma vez que concede voz simbólica àqueles que se encontram alienados pelo sistema. O discurso colonial representa esta alienação imposta ao indivíduo a fim de melhor controlá-lo, representa um conjunto de práticas sistematizadas que visam a privação da memória cultural e da consciência identitária do colonizado.

O condão da proposta glissantiana da Relação e da comunhão deve-se, nesse sentido, justamente à sábia aliança de suas reflexões acerca da experiência da dominação do povo antilhano com uma nova perspectiva que desenvolve sobre a formação das identidades culturais no mundo pós-colonial.

Assim, ao lado da ação política, configura-se o itinerário filosófico do escritor. Em seus ensaios e textos ficcionais, o escritor semeia conceitos fundamentais que, paulatinamente, vão unir-se em complexas cadeias associativas, gerando um feixe de proposições teóricas à luz das quais toda a obra pode ser lida e interpretada. Trata-se de um processo de autorreflexão que permeia o trabalho de Glissant, em que a filosofia surge como "um domínio essencial permitindo novos combates" (RADFORD, 1982, p. 17), célula original do pensamento deste autor.

Basta acentuar, a esse respeito, que as próprias noções (análogas) de "pensamento construído" e de "formação de pensamento", as quais possuem papel central na escrita glissantiana, repousam numa práxis filosófica específica, no caso aquela da redução fenomenológica. Tomado de empréstimo a Jean Wahl, este princípio define a preponderância

\footnotetext{
${ }^{35}$ A associação Front des Antillais et Guyanais pour l'autonomie, também chamada de Front Antillo-Guyanais, foi fundada em 1961 por Édouard Glissant com o apoio de Paul Niger, Marcel Manville e Cosnay Marie-Joseph, tendo por objetivo a emancipação político-administrativa dos departamentos franceses das Antilhas e Guiana. O Front foi dissolvido, por decreto presidencial, cerca de três meses após a primeira conferência do grupo.
} 
da memória na elaboração do pensamento, ao mesmo tempo em que lhe atribui certo caráter imediatista ${ }^{36}$.

É Romuald-Blaise Fonkoua (2002, p. 51) quem afirma que, para o autor martiniquense, esta ideia veio trazer a possibilidade de rever os caminhos da diáspora negra e de associar uma outra significação à cultura dos povos escravizados no Ocidente, geralmente considerados como "sem memória". Segundo entende Fonkoua:

Jean Wahl esperava reduzir a distância entre o tempo da ciência e o tempo da consciência pela poesia. Glissant tomava consciência, assim, de que sua prática da poesia, bem anterior à viagem à Europa, não era empírica. Ela era, como em Wahl, a forma mais adequada para exprimir o inexprimível do deslocamento da escravidão e da descoberta de um mundo desconhecido, as Índias, e o reconhecimento de um lugar único, o eu antilhano. [...] Assim como Wahl concebe que o cogito é um pensamento instantâneo [...]; que este cogito não pode ser apreendido senão pela poesia, assim Glissant entrevê na redução fenomenológica a possibilidade de pensar o impensável no instante, de fazer surgir do caos, pela poesia, todas as suas verdades instantâneas, de religar enfim um mundo desconhecido do passado a um devir ainda mais desconhecido (FONKOUA, 2002, p. 51).

Divisa-se, graças à admirável leitura de Fonkoua, uma ligação orgânica entre a proposição existencial de Wahl e o pensamento relacional de Glissant, especialmente naquilo que concerne à temporalidade (poética da duração x poética do instante), ao apreensível e ao dizível (dizível poético x indizível poético) e, por fim, à história e à memória (transparência x opacidade). O núcleo da Relação, percebe-se então, não é outro senão aquele fornecido pela redução fenomenológica que distingue a memória e o instante como substâncias particulares do pensamento.

E é justamente neste eixo epistemológico que o autor sustenta os conceitos que organizam seu pensamento, os quais, "surgidos do caos das ideias", são por vezes de difícil apreensão, mas coerentes quando contextualizados pela filosofia glissantiana, conforme expõe Jean-Pol Madou (1996):

O discurso poético de Glissant se articula à intersecção de três problemáticas fundamentais, cada uma constituindo um campo polarizado por uma série de oposições, e as quais o autor fará suportar um deslocamento em relação ao seu lugar de origem: um campo filosófico constituído pelo entrelaçamento de quatro tipos de relações ontológicas: o Um e o Diverso, o Mesmo e o Outro, o Ser e o Não-Ser, o instante e a duração; um campo poético tensionado entre a Poesia e o Relato, entre a exigência do canto e a pulsão narrativa; um campo geopolítico opondo e ligando, ao mesmo tempo, as forças de desterritorialização e de reterritorialização [...] (MADOU, 1996, p. 10).

\footnotetext{
${ }^{36}$ Remetemos o leitor à obra deste filósofo: WAHL, Jean. Du rôle de l'idée de l'instant dans la philosophie de Decartes. Paris: Descartes \& Cie, 1994. [Tese orig. sustentada em 1920].
} 
Todos níveis formadores da linguagem crítica de Glissant e definidores de seus principais objetos reflexivos.

\section{Emancipação e autonomia}

A propósito desta aproximação entre ação política e itinerário filosófico em Glissant, uma vez mais deve-se reforçar o dado da legitimação frente ao meio de origem do autor em situação colonial. A preocupação revelada por Glissant quanto à necessidade de uma formação completa em filosofia, que considerava como ciência-mãe de todas as humanidades, e sua tomada de posição política já significativa no início dos anos 1950 a favor da liberação dos territórios de ultramar sob tutela francesa articulam-se à busca pela afirmação da independência e autonomia de sua terra-natal, na medida em que sua própria independência e autonomia enquanto pensador dependiam da construção deste lugar de cultura e identidade livres, emancipado do jugo da metrópole europeia.

Como expõe Patrick Chamoiseau em seu livro Écrire en pays dominé (1997), a questão é um completo dilema, pois a dependência política interfere diretamente na relação do escritor com a linguagem, afetando sua prática da escrita e sua formação de pensamento:

Como escrever agora que teu imaginário se enche, da manhã até os sonhos, de imagens, de pensamentos, de valores que não são os teus? Como escrever quando aquilo que tu és vegeta fora dos transportes que determinam tua vida?

Como escrever, dominado? (CHAMOISEAU, 1997, p. 17).

Note-se, como reforço, que o pensador martiniquense não procurou deslocar-se da periferia do mundo colonial (as Antilhas) para legitimar-se num centro de saber já consolidado (a França), o que não era raro entre os escritores colonizados, mas investiu, bem ao contrário, em modos de proclamar a originalidade de seu arquipélago, redescobrindo a linguagem e a poesia e através delas fundando a autenticidade de um discurso antilhano.

O sistema filosófico de Glissant, portanto, insere-se nesta linha de legitimação de sua condição de escritor, servindo propriamente ao seu esforço de interpretação da diversidade cultural das Antilhas, cujo ápice e mais emblemática representação, segundo Diva Damato, é Le Discours antillais:

Reunindo parte considerável da produção teórica de Glissant (conferências, artigos, comunicações em congressos, textos para catálogos de exposições de pintura, prefácios, etc.) relativa a um período de dez anos, assim como reflexões sobre publicações anteriores, esse livro é considerado como uma espécie de suma na sua tentativa de abarcar o real antilhano [...] (DAMATO, 1996, p. 19). 
De fato, pontuando a curva de um arco ideal entre o engajamento político e o estudo filosófico, Le Discours antillais completa a longa série de ações e reflexões de Glissant no sentido de desvendar a cultura e a identidade antilhana, revelando um "pesquisador infatigável, com uma riquíssima produção teórica, empenhado em descobrir novos caminhos (ou trilhar os antigos com novo olhar) à procura de pistas que pudessem elucidar a realidade de sua ilha" (DAMATO, 1996, pp. 19-20).

Se a construção de um lugar de enunciação independente mobilizou boa parte dos escritos de Glissant, a busca pela revelação da realidade antilhana foi igualmente fundamental para a deflagração dos principais conceitos que estruturam seu projeto literário. Este projeto também se traduz, para o autor, como uma "intenção" poética, isto é, uma proposta de leitura da diversidade cultural das Antilhas através da conquista do espaço, da história e da língua.

Como explica Diva Damato (1996, p. 22), o arquipélago é assumido por Glissant como "o lugar de uma tripla depossessão", que corresponde a essas respectivas instâncias, e "por meio da literatura o escritor tentaria apropriar-se dessa paisagem, desse passado, dessa palavra, de que o seu povo fora espoliado, dando assim a sua contribuição específica - como escritor - para a construção da nação [...]” (DAMATO, 1996, p. 22). E não apenas isso, mas para o despertar da consciência antilhana, para a afirmação de sua identidade e dos valores particulares de sua cultura.

Le Discours antillais, diga-se novamente, representa o coroamento desta ação engajada de Édouard Glissant, mas também, de acordo com o que foi mencionado no início deste capítulo, um divisor de águas em sua produção. A partir desta obra e dos núcleos epistemológicos que traz, o autor levou seus conceitos para além das fronteiras do cosmo cultural antilhano, percebendo que a Relação, o Diverso e o Todo-mundo ${ }^{37}$ são noções que dizem muito acerca das próprias relações entre povos, línguas e culturas na "totalidade realizada" do mundo moderno.

Esta é, enfim, a grande intuição do pensador martiniquense enquanto escritor-filósofo e intelectual: vislumbrar na experiência local da diversidade antilhana um meio para refletir sobre a diversidade em escala global.

\footnotetext{
37 "Eu chamo Todo-mundo nosso universo tal como ele muda e perdura cambiando e, ao mesmo tempo, a 'visão' que temos dele" (GLISSANT, 1997, p, 176).
} 


\section{Capítulo VII: O programa identitário em Le Discours antillais}

\section{Uma intensa relação entre forma e conteúdo}

Glissant procurou, através de Le Discours antillais, passar em revista os mais variados aspectos do real antilhano, desde a história colonial, passando pela sociedade e pela linguagem, até a política, com o propósito maior de alcançar a identidade cultural de seu povo, o que por si só representa um considerável esforço intelectual. E a escrita bem o revela, destacando-se a ideia de edificação de um grande complexo epistemológico e de agregação de matérias multiformes, onde figuram amiúde conceitos difíceis de serem captados e interpretados. A Relação e o Diverso, conforme visto até aqui, são exemplos dessa ação engajada e, sobretudo, do processo reflexivo encaminhado pelo autor.

Neste volume ensaístico configurado como uma espécie de puzzle ou mosaico textual diversificado, o escritor empenha-se em afirmar a dinâmica antilhana, ao mesmo tempo em que traça grandes eixos de sua obra, no sentido próximo de um movimento de autorreflexão e experimentação. É explorada a "não-história" local, determinada pelo tráfico negreiro, pela escravidão e pela departamentalização; faz-se a crítica do colonialismo; cria-se a integração aos estudos culturais; propõe-se um novo olhar acerca das literaturas emergentes, etc. De modo que o pensamento do autor não se limita às Antilhas francófonas, mas abrange todo o Caribe e além, ao voltar-se para a "totalidade-mundo".

Como projeto completo da pesquisa identitária antilhana, Le Discours antillais traz grandes contrastes em seu itinerário e não segue métodos aparentes. Em suas páginas, o autor anuncia um intento, introduzindo a problemática cultural da região, aspectos históricos e linguísticos que se relacionam, e chamando a atenção também para o imperativo de um discurso independente e para o fato de que apenas através dele, ou seja, do domínio de uma linguagem organizada em saber, é possível alcançar a autodeterminação. Uma fina ironia ajusta-se, então, à crítica pungente contra a ação do colonizador, contra a "assistência" político-administrativa, contra as imposições consentidas (paradoxo!), contra a alienação e sua forma mais extrema, a assimilação cultural. $\mathrm{O}$ escritor, no sentido de intervir produtivamente, reivindica mudanças, propõe novas perspectivas, dispõe de planos-síntese e de manifestos pela revisão do tempo, da memória, da história, da cultura e da identidade antilhana. 
$\mathrm{O}$ autor percebe, nesse processo, a dificuldade de se acercar de seu objeto e ainda os riscos colocados pela própria formulação teórica que se aplica. Em seu discurso crítico chega inclusive a fazer a advertência destes percalços:

Tratar-se-ia de rastrear à força os processos multiplicados, os vetores embaraçados que, ao cabo, teceram para um povo, o qual dispunha de tantos quadros e de indivíduos "formados", a tela de nulidade na qual ele está retido.

Esforço "intelectual”, com suas crises de repetição (a repetição é um ritmo), seus momentos contraditórios, suas exigências de uma formulação ao limite esquematizada, muito frequentemente obscurecida por seu objeto mesmo. Pois a tentativa de aproximar uma realidade tantas vezes ocultada não se ordena de repente em torno de uma série de claridades. Nós reclamamos o direito à opacidade (GLISSANT, 1981, p. 11).

Trata-se, com efeito, de uma demonstração de serena responsabilidade da parte de Glissant a menção aos impasses e possíveis contradições de uma tal obra. À vista da "realidade tantas vezes ocultada" é natural que haja um ofuscamento, assim como ocorre quando se passa das trevas à luz, imagem esta definitiva legada por Platão no "Mito da caverna". Porque o objeto discutido esteve por muito tempo nas sombras, isto é, porque a identidade cultural antilhana esteve por tanto tempo à margem de qualquer debate e como que alijada, não se pode esperar que de um só golpe seja plenamente esclarecida (esclarecer é trazer à luz), mas é preciso considerar com tolerância as repetições, as contradições e dilemas suscitados no decurso de seu exame. Isso o escritor prevê e alerta o leitor, talvez para que não experimente demasiado estranhamento ao percorrer os caminhos pelos quais será guiado.

A estudiosa brasileira de Édouard Glissant, Diva Damato, da mesma forma apontou os desafios da leitura de Le Discours antillais, "tanto na forma como no conteúdo", ao ponderar a grandeza do trabalho, dizendo:

\begin{abstract}
A importância do Discours (e a dificuldade de sua leitura) vem exatamente de sua diversidade, quer no conteúdo quer na forma. Ao tratar dos mais variados assuntos, ora de maneira sistemática (em geral as transcrições de artigos e conferências), ora em forma de fragmentos, ao encadear espaços em branco, textos teóricos, textos poéticos, depoimentos de populares e místicos, documentos históricos, relatos de experiências pessoais, numa sequência que nem sempre é clara para o leitor, Glissant evidencia que o estudo de uma situação tão original e tão complexa quanto a da Martinica exige uma nova forma de abordagem. Posto que, para ele, "o método nunca é inocente", uma de suas preocupações será a de escapar das armadilhas da lógica cartesiana, do formalismo acadêmico [...] (DAMATO, 1996, p. 20).
\end{abstract}

Então seria plausível ver nessa recolha de fragmentos, nessa colcha de retalhos tão variados, a intenção de estabelecer um jogo (ludus) estético-epistemológico no qual a diversidade formal (estética) e a diversidade de conteúdo (epistemológica) aludiria à fundamental diversidade antilhana? A se confirmar tal hipótese, cada entrada ou seção do livro 
poderia ser assumida metaforicamente como uma "ilha" e o próprio livro seria um vasto arquipélago - o Caribe.

A dialética do saber popular e do saber intelectual, característica do estudo da identidade cultural antilhana, também está presente aqui, valendo a observação da justaposição de textos formais e relatos de indivíduos vinculados às tradições locais mais expressivas (o descendente marron, o feiticeiro, o cantador).

Neste volume há que se enfatizar, principalmente, que a forma inovadora vem ao encontro da originalidade do assunto tratado e que a postura de recusa dos modelos teóricos formais (clarté) admitida por Glissant concorre para uma defesa - inversa - da opacidade (opacité). Significa dizer que, em lugar da unidade das formas fixas, o autor propõe a mobilidade de um texto "insular" e, em lugar da revelação absoluta e incontestável prometida pela lógica dos sistemas, propõe uma percepção relacional da diversidade.

Ora, o anúncio desta maneira idiossincrática de proceder à abordagem da questão identitária antilhana se faz nos seguintes termos:

A intenção neste trabalho foi de acumular em todos os níveis. A acumulação é a
técnica mais apropriada de desvelamento de uma realidade que, ela mesma, se
dispersa. Seu desdobramento se aparenta de algumas obsessões que enraízam, ligadas
a evidências que viajam. O trajeto intelectual está consagrado a um itinerário
geográfico, pelo que o "pensamento" do Discurso explora seu espaço e se trança.
As Antilhas, a outra América. Tamborilar sem descanso as ideias-forças que levarão
talvez a seu espaço em nós. O repetido dessas ideias não faz a fala mais clara, ao
contrário, ele a torna opaca provavelmente. Nós temos necessidade dessas espessuras
teimosas onde as reditas tramam para nós um contínuo encerramento, pelo que nós
nos oporemos.
Resumo de um trajeto, relato de uma viagem no universo americano, este discurso
multiplicado porta a marca da exposição oral, se conformando assim a um de seus
mais devassados tormentos. Quando o oral confronta enfim o escrito, as misérias
acumuladas secretas amiúde falam: o indivíduo sai do círculo estreito. Para além de
toda derrisão vivida, um sentido coletivo, uma poética do universo, onde cada voz
conta, onde cada vivido explica.
(Assim o discurso antilhano não se oferece de um golpe. Mas o mundo, em sua
unidade deflagrada, não requer que cada um se esforce em direção da opacidade
reconhecida do outro? Eis uma parcela de nossa opacidade.) (GLISSANT, 1981, p.
13, grifo do autor).

De acordo com o autor, a obra se faz périplo e jornada de descoberta do Novo Mundo, cujo ponto de partida, na ótica glissantiana, seria o Caribe, espécie de prelúdio da multiplicidade cultural, linguística e étnica que se observa pelo continente afora. Para que se chegue a apreender a diversidade deste contexto, Glissant destaca como técnica mais adequada a acumulação, o que se reflete na disposição geral de seu livro: uma sequência de informes, notícias, relatos, notas, manifestos, etc. 
Diante de uma realidade fugidia e cambiante que "se dispersa" ela mesma, este método constitui a possibilidade de flagrar no instante suas marcas e assim fundar seu tempo, sua memória e identidade. As Antilhas figuram como a "outra América", um espaço a ser conquistado, espaço que desafia as ideias, exigindo a opacidade, que é o estado de conciliação e respeito à singularidade e à particularidade.

Por outro lado, o discurso da oralidade é eleito como o meio orgânico de expor a realidade local e de expressar a experiência da diversidade ali vivida. Entre a comunicação oral e a prática da escrita revela-se o "caos-mundo", a desordem que provoca os indivíduos a deixarem o "círculo estreito" das ideias previstas e integrarem a "poética do universo", poética polifônica. Eis um gesto em direção ao outro, da alteridade à diversidade, que sugere o reconhecimento da opacidade (direito a singularidade) de cada um, em que o discurso antilhano leva a novos discursos na Relação.

\section{Discurso e demandas}

Glissant (1981, p. 435) afirma que uma "poética é talvez uma ambição (realizada ou não) tanto quanto (isto é, ao mesmo tempo que) uma organização das palavras". Ora, o projeto relacional global enunciado em Le Discours antillais, por participar de uma rede conceitual mais ampla, ou seja, de uma poética específica, se estabelece como uma forma organizada de princípios ou termos reivindicativos manifestos no discurso. A organização das palavras, então, segue a proposição da demanda identitária antilhana expressamente definida pelo escritor, que ordena sua busca nos moldes de um plano poético, um tipo arquitetural de baixa-planta da identidade a ser construída:

Eu resumo em forma de litania os dados de nossa busca de identidade. A litania convém aqui bem mais que o discurso.

O tráfico de escravos como extirpação à matriz

(a mãe inacessível)

A escravidão como combate sem testemunho

(a palavra sussurrada nas cabanas)

A perda da memória coletiva

(a vertigem do tempo)

A evidência do outro

(a transparência do "universal")

A armadilha folclórica

(o não-projeto intelectual) 
A armadilha do estado civil

(a ideia fixa do nome)

A armadilha linguística

(a dominância)

A não-responsabilidade técnica

(o utensílio, estranho)

A imediatez

(o reboar direto das pressões)

A “suspensão" política

(o medo do reporte ao mundo)

A consumação passiva

(exacerbado)

A nulização

(nem fazer nem criar)

O sistema de muda

(A Martinica, terra de passagem)

O subterfúgio do détour

(a "sabedoria" popular)

A sobrevivência pela subsistência

(a vida ao lado dos limites)

A abertura multilíngue

(no começo da diglossia)

A abertura caribe

(a orla do espaço-tempo)

O passado reconhecido

(as faltas ultrapassadas)

A nação que lancina

(a resolução autônoma dos conflitos de classe)

O oral - o escrito

(o desbloqueio das inibições)

Um povo que se exprime

(o país que se reúne)

Um povo político

(o país que age) (GLISSANT, 1981, pp. 435-437).

Existe no quadro descrito uma toada dos reparos e demandas necessários a constituição da identidade cultural antilhana, daí a remissão autoral à litania, a partir do que são percebidos os diferentes pontos que participam desta complexa questão: o tráfico, a escravidão, a perda da memória coletiva, o drama linguístico, etc. Tais aspectos estão, por sua vez, vinculados à crítica do colonialismo, ao problema da alteridade, à ação política, ao projeto poético de Glissant e à 
sua procura pela apreensão do real caribenho. Este movimento geral converte-se, enfim, em proposta de apreensão das culturas na "totalidade-mundo", seja por meio da Relação, do Diverso ou mesmo da "crioulização".

Do ponto de vista da ação engajada, é marcante a consideração que se toma na sequência deste quadro propositivo, especificamente quando o pensador martiniquense diz:

[...] ao cabo de nossa errância enraizada, a vontade sem retenção de propor para esta ação as vias específicas, tramadas em nosso real e não caídas do céu das ideologias; a verdade não menos forte de nos encerrarmos para tanto nos sectarismos a priori daqueles que não meditam a Relação dos povos; para esta reunião, a audácia criadora coletiva, para a qual cada um contribuirá.

Não é um amém que fecha a litania: pois nós vemos, esparsa na falta, longe no fundo da derrisão, esta nova noite das cabanas nas quais nos reunimos, para sussurrar ainda, raspadas do fundo das gargantas, nossas vozes (GLISSANT, 1981, p. 437).

A conquista da identidade, segundo o autor, passa pela Relação dos povos, isto é, exatamente pela dinâmica das culturas e pela diversidade, não podendo ser alcançada senão pela partilha e pela potência criadora, na qual cumpre que todos participem. Aqui é a comunhão das vozes que constrói o discurso das culturas na modernidade, "a irrupção na modernidade" que Glissant (1981, p. 256, grifo do autor) considera como traço comum entre a comunidade antilhana em busca de identidade e os outros povos cujas identidades se transformam através do tempo.

Eis aí o modo pelo qual está organizado o debate da questão identitária antilhana em Édouard Glissant e os principais eixos de questionamento/pleito/defesa que o autor considera ao abordar criticamente o tema. Conforme a economia do texto, Le Discours antillais se apresenta como espaço de afirmação cultural onde primeiro se discute em profundidade a problemática colonial, o processo de assimilação e a tutela francesa sob a política de departamentalização, entre outros dados da realidade antilhana. E deriva desta soma de planos de reflexão o caráter multidisciplinar da obra, que envolve em sua trama disposições próprias das ciências humanas, da literatura, da filosofia, da linguística, da antropologia etc., evidenciando assim o traço eminentemente humanístico da formação glissantiana.

A partir desse registro de saberes, Glissant interpreta o grande obstáculo à pesquisa identitária antilhana como sendo a alienação da população, que sofre a dependência política, econômica e cultural em relação à metrópole - problema, aliás conhecido por todas as sociedades coloniais. Diante disso, afirma o escritor: 
trabalho autônomo, alienado ou não, a partir do que manifestar esta busca (GLISSANT, 1981, p. 167).

Conforme se observa, na rede de conhecimentos formada em Le Discours antillais, o dado social ocupa lugar destacado no sentido da discussão da problemática identitária, pois está implicado no processo mais amplo e primitivo da colonização, trazendo suas marcas e dilemas. Mas, ao lado desse aspecto social inicialmente referido, surge outro de igual força no cômputo da pesquisa de identidades, o qual corresponde ao plano político. Não se trata, nesse caso, da política como expressão administrativa ou de governo, porém (e melhor dizendo) de políticas institucionais de demanda e reconhecimento, que são mobilizadas na situação em que as relações identitárias, suas interações, são elas mesmas postas em jogo. Isso ocorre quando identidades tornam-se "objeto de representações inadequadas ou não são reconhecidas no quadro de relações instituídas de reconhecimento mútuo" e então "uma identidade estrangeira lhes é imposta por meio de um processo de subordinação, seja assimilando-as à identidade dominante, seja relegando-as à esfera da marginalidade [...]” (TULLY, 2000, p. 198).

No particular das Antilhas, como pondera Glissant, há um risco de perda e dissolução da identidade crioula local frente ao domínio massivo, em diversas áreas, do antigo colonizador. A luta pela afirmação da identidade cultural antilhana deflagrada no Discours, nesse âmbito, vale por todo um movimento pela autodeterminação dos povos e de apoio à diversidade, no qual o autor martiniquense é um pioneiro. Segundo James Tully (2000, p. 202), o objetivo das políticas identitárias seria "encorajar a tomada de consciência e o respeito da diversidade em todas as esferas da sociedade, de sorte que todos possam participar na base de um respeito mútuo" das relações interculturais que abrangem línguas e etnias ao redor do mundo.

Glissant trata também desta questão da luta pela diversidade ao refletir sobre a realidade das ilhas caribenhas, onde a cultura local da resistência, forjada na hibridização e na "crioulização", é ameaçada pela assistência (e pelo peso) dos valores da metrópole. O autor registra, a esse propósito, a importância da tomada de consciência acerca do reconhecimento das identidades em sua multiplicidade, respeitadas as idiossincrasias de cada expressão indentitária e o dado das inter-relações culturais e linguísticas ("mundialidade"38).

Naquilo que tange à pesquisa da identidade, como esclarece Tully (2000, p. 202, grifo do autor), a "reivindicação em favor da diversidade cultural corresponde a um primeiro tipo de luta", um primeiro momento de engajamento que "visa o reconhecimento mútuo e o respeito

\footnotetext{
38 "A mundialidade, se ela se verifica nas opressões e nas explorações dos fracos pelos fortes, se advinha também e se vive pelas poéticas, longe de toda generalização" (GLISSANT, 1997, p. 176).
} 
das diferenças identitárias oriundas da esfera cultural", ou seja, representa uma ação de oposição ao totalitarismo, aos princípios fixos e estereótipos que se encontram na base dos discursos que negam a diferença.

A lembrança da poética da Relação e da poética do Diverso basta para expor a atitude de Glissant face ao problema, demonstrando o empenho do autor na crítica do colonialismo e de seu aparato teórico, na contestação do Mesmo generalizante e da História ocidental (etnocêntrica). Por ter a experiência da cultura da diversidade e por ter consciência da necessidade de afirmação da identidade antilhana, Glissant participa desta outra forma de reivindicação que é a partilha, ou seja, pela aceitação de todas as línguas, de todos os espaços e de todas as culturas em franca abertura. Seria, então, a plena comunhão daquilo que o escritor nomeia "o sal da Diversidade" (GLISSANT, 1993, p. 407).

\section{Uma obra aberta}

A publicação, em 1981, de Le Discours antillais marcou o início de um processo de leitura da realidade cultural dos povos e de defesa da diversidade cujos frutos amadureceriam na década seguinte em uma série de trabalhos voltados à reflexão sobre o tema da identidade, já de maneira extensiva e para além do paradigma antilhano. Dentre estes textos, destacam-se Poétique de la Relation, Faulkner, Mississippi e Traité du Tout-monde, que definem (completam) o projeto filosófico-literário global de Glissant. Nesse sentido, é importante insistir na ideia de ampliação da experiência vivida nas Antilhas, pois as proposições tomadas ao longo do livro nos moldes da pesquisa identitária passaram a valer positivamente para a totalidade das relações e interações entre culturas no mundo. A região insular seria, assim, precursora de um movimento global.

Por fim, as estratégias discursivas e o modo de organização da questão identitária, tal como se apresentam em Le Discours antillais, articulados a diferentes frentes da crítica glissantiana (ao colonialismo, ao etnocentrismo, ao Mesmo redutor...), revelam uma proposta de apreensão e reformulação das noções mesmas de cultura e identidade sob a ótica da Relação e do Diverso, conceitos-chave do pensamento de Édouard Glissant e de sua poética.

Concentrado em um projeto de considerável porte epistemológico, o escritor pondera o alcance de suas reflexões, considerando que a pesquisa identitária pode associar-se ao programa da diversidade cultural, promovendo, então, a abertura de sua obra para a totalidade, 
que concebe a partir dos avatares da "crioulização" e da integração. E é esta abertura, ao cabo, que responde pela dinâmica da fala glissantiana, capaz de ampla abrangência em sua consistência construtiva e criadora de novas ideias. 


\section{Capítulo VIII: Um discurso da diversidade}

\section{O discurso fundador}

Um discurso é um desenvolvimento reflexivo sobre determinado tema, é a expressão verbal do pensamento. A escolha deste termo por Glissant para o título de seu célebre livro não é meramente retórica, mas reflete o fato de a noção de discurso, no domínio da linguística, corresponder a um conjunto de enunciados, de mensagens faladas ou escritas, que se opõe a ideia de sistema, o que poderia ser visto como um primeiro dado da recusa manifesta pelo autor frente a modelos epistemológicos fixos e deterministas, conforme a leitura da obra vem confirmar através de sua constituição fragmentária, de expressão quase oral, baseada justamente em um conjunto heteróclito de excertos.

O chamado "discurso antilhano" revela, assim, uma dupla acepção: incialmente, como mise en cuvre de reflexões sobre a realidade de uma cultura, e depois, como voz simbólica desta mesma cultura, aquela pela qual revelar-se-á. Discurso este que enfeixa formalmente uma série de proposições acerca da problemática identitária antilhana, explorando as múltiplas facetas da realidade cultural daquela comunidade, que pretende abarcar em termos poéticos e filosóficos e apresentar sob uma perspectiva relacional.

A partir do exercício vertiginoso da linguagem, que não é outro senão o de "acumular em todos os níveis" (GLISSANT, 1981, p. 13), ou seja, de somar saberes e linhas de abordagem no sentido de desvendar uma realidade encerrada em si mesma, surge a proposta de um novo olhar sobre a diversidade, que o autor apreende em seu dinamismo e fulgurância: "Correr o risco Terra, ousar a exploração de seus transportes interditos, ou ignorados. Estando por aí nossa morada própria. As histórias dos povos são o cúmulo de nossa poética" (GLISSANT, 1981, p. 13).

E também "a partir deste discurso sobre um discurso" "39 Glissant enfatiza a multiplicidade como aspecto fundamental que vai ao encontro da "marca da exposição oral" (GLISSANT, 1981, p. 13), sendo o oral a máxima da expressão, responsável pela abertura de horizontes aos indivíduos. Mas, longe de ser uma travessia fácil, o discurso assim estabelecido delineia tortuosas veredas, como uma espécie de conglomerado rizomático que pretende

\footnotetext{
39 “A partir de ce discours sur un discours", entrada da seção 2 de Le Discours antillais.
} 
mimetizar os imprevisíveis contornos da diversidade que tem por objetivo debater, conforme fica assentado para o autor:

A meu ver o Discours é uma soma arqueológica a tal ponto vertiginosa que um leitor
ou uma leitora, sozinho, não saberia esgotá-lo com satisfação. Há cruzamentos,
entrecruzamentos, da História, da literatura, da poética, da sociologia, da economia,
da política. Este entrecruzamento é a tal ponto complexo que toda leitura linear está
certamente consagrada ao fracasso (GLISSANT, 1983, apud DAMATO, 1996, p. 19).

O pensador martiniquense introduz sua obra tal como fonte caudalosa, impossível de ser esgotada totalmente num esforço de leitura, e adverte sobre os perigos de se buscar aplicar a semelhante texto uma "leitura linear", ao mesmo tempo em que afirma a complexidade da rede de assuntos ali desenvolvidos, oferecendo ao intérprete, a esse propósito, um importante conselho, senão mesmo o fio de Ariadne de seu livro. O texto, por isso, exige uma abordagem dinâmica, multifocal e diversificada, capaz de captar de sua estrutura proteiforme e de sua rede conceitual a ideia-imagem ${ }^{40}$ tecida no complexo "entrecruzamento" disciplinar que apresenta.

Seria este discurso, conforme o exposto, uma "soma arqueológica" dos diferentes aspectos que caracterizam o contexto cuja análise o autor procura levar a efeito, isto é, uma substancial recolha de matérias de origens variadas que figuram como artefatos a serem investigados, os quais trariam pistas sobre o passado de uma cultura em busca de sua memória coletiva, de sua identidade. Glissant, por isso, pode ser visto no papel de arqueólogo que reconstitui este passado a partir do registro dos fragmentos que dele restaram, o que termina por justificar a mobilização, em sua exposição, de recursos provenientes do mais amplo espectro de conhecimentos (história, antropologia, literatura, política, etc.).

Como nota de curiosidade, seja visto que a noção de "discurso sobre um discurso" leva a pensar na própria ideia de "cultura como um discurso" ${ }^{41}$ que opera em diversas frentes, incorporando a linguagem, as tradições, as artes e demais patrimônios partilhados por um grupo, como expressão mesma de sua memória e identidade. Nesse sentido, o discurso estabelecido por Glissant, enquanto procedimento reflexivo, está voltado para o exame de um outro "discurso", ou seja, a cultura antilhana, tomada em sua multiplicidade de representações, em suas incoerências e contrastes, bem como em sua potencialidade e ensinamentos. Assim, o objeto de Le Discours antillais é ele mesmo assumido como um "discurso", que ali identificase com o conceito de cultura, de modo que o autor, ao assumir tal relação entre exame e matéria,

\footnotetext{
${ }^{40}$ Empregamos esta expressão, em linguagem experimental, por nos parecer representativa do caráter impalpável e sutil, essencialmente abstrato, embora reconhecível, do conteúdo da obra glissantiana.

${ }^{41}$ Cf. Hall (2006, p. 50), já citado no capítulo I desta pesquisa.
} 
acaba por multiplicar a semântica do termo que adota, promovendo uma verdadeira explosão dos sentidos.

Daí a ideia de um "discurso da diversidade" que, a um só tempo, reflete e penetra o real antilhano eivado pelo diverso, pelo múltiplo, pelo heterogêneo, os quais remetem a um processo que o mundo inteiro experimenta hoje, quando as culturas e identidades passam pela lógica relacional da flexibilidade, amiúde pela fragmentação e pela impermanência, em substituição aos antigos quadros de estabilidade e fixidez. Sendo novamente a experiência da diversidade vivida nas Antilhas a fornecer o paradigma deste movimento global, seja por meio do hibridismo tanto étnico quanto linguístico de sua comunidade ou da abertura fractal de sua geografia insular, demonstrando a contingência da linguagem e a força dos contatos entre os povos num contexto onde as culturas não figuram restritas a quaisquer territórios, mas viajam através dos espaços.

Esta é, afinal, a exata medida da potencialidade da cultura antilhana, manifesta na diversidade e na afirmação das diferenças, antecipando um movimento que caracteriza em seu conteúdo e expressão a modernidade. O discurso proposto por Glissant como meio de investigação do real antilhano e como plataforma de acesso à identidade cultural daquela comunidade transforma-se, assim, em possibilidade de diálogo entre culturas na "totalidademundo", possibilidade de integração e intermediação comunicativa.

Trata-se, pois, de um discurso que, ao reclamar a diversidade - nada mais que a situação concreta das Antilhas - e ao anunciar o advento do "nós", reabilita a memória impedida de se sedimentar pelos dramas históricos da formação social antilhana, resgatando o sentido fundamental da "crioulização" como adaptação e transformação, como processo de resistência e sobrevivência cultural, principalmente como resposta à rigidez identitária e ao mito da raiz única.

\section{O discurso caótico}

Aqui, precisamente, emerge outra concepção do discurso glissantiano, agora como fenômeno da linguagem, ou melhor dizendo, como resultado de uma ação sobre a linguagem que visa desconstruir as velhas categorias sócio-discursivas já desconformes com a realidade cultural do mundo contemporâneo, discurso este que adota a expressão oral, as falhas da comunicação, suas pausas e silêncios, numa disposição não-linear e não-presumida, 
apresentando por isso um caráter "aparentemente delirante, porque está em contradição com o discurso corrente", quando na verdade é a "única testemunha perceptível de uma fala verdadeira" (CHANCÉ, 2001, p. 163).

E, ainda de acordo com a leitura sugerida por Dominique Chancé (2001), o discurso glissantiano revela a "verdade de uma situação", a qual bem poderia ser tratada como consequência da expansão da diversidade e da dissolução das tradicionais concepções que introduzem as identidades como dados fixos e imutáveis. Nas palavras da pesquisadora:

O autor, numa tal situação, é aquele que, a exemplo do analista, entende algo dos lapsos, dos atos falhos, das falhas do discurso, que revelam a tensão entre o discurso manifesto, manifestamente fora de prumo, e o desejo verdadeiro, ético quanto libidinal, que sustentaria o sujeito, se este pudesse reconhecê-lo por sua vez. O escritor é aquele que dá a entender o discurso delirante, e que mesmo fala, por um lado, esse discurso (CHANCÉ, 2001, p. 163).

Enquanto fenômeno da linguagem em processo de transformação, o discurso glissantiano, tanto em sua dimensão literária quanto filosófica, traz as marcas da tensão entre dois sistemas culturais distintos, isto é, entre o mundo europeu da escrita codificada e regrada e o mundo antilhano da oralidade, em que pesem as ressonâncias dessa tensão no desenvolvimento do pensamento e sua consequente expressão verbal, donde poder-se-ia pensar que derivam “as sentenças obscuras, insanas, 'opacas' no léxico glissantiano" (CHANCÉ, 2001, p. 163), além dos próprios "conceitos de difícil apreensão" que organizam sua poética.

Daí talvez a insólita configuração discursiva e formal de Le Discours antillais, assumida como parte da proposta de uma escrita criativa consoante ao caráter da matéria de que se ocupa o autor, objetivamente voltada para a questão identitária antilhana e metaforicamente dirigida ao fluxo da diversidade na "totalidade-mundo".

Destarte, retomando a derradeira ideia de escrita criativa, seria possível observar em detalhe a atitude do pensador martiniquense no sentido mesmo da construção de seu "discurso sobre um discurso", sem que se perca de vista, entretanto, a relação já assinalada entre discurso crítico e cultura como discurso. A oportunidade para tal observação, Glissant a concede num apêndice de Poétique de la Relation:

Uma das condições do exercício da escrita hoje não é que ele se veja precedido do discurso? É, em todo caso, o que acontece o mais frequentemente: eu aceito convites para expor publicamente pontos de vista, cada vez que a reunião proposta convém ao meu projeto (não projetando). Acontece por vezes que o tema sugerido desdobra outros prolongamentos, radículas, variantes inéditas.

A apresentação pública funciona como uma espécie de rascunho do texto escrito que dela resultará. Mas esta apresentação terá entrementes decidido linguagens deste 
texto, orientado sua economia. A prática da escrita encerrará depois, ou estenderá, o que a apresentação houver liberado (GLISSANT, 1990, p. 239).

Destaca-se, assim, do trecho ilustrado, a semelhança com o pensamento evocado em Le Discours antillais, quando o autor diz que seu discurso porta a "marca da exposição oral", ou seja, na medida em que tal discurso se constitui como expressão verbal do pensamento e antecede a sua organização escrita, etapa posterior que the é condicionada. Sendo esta disposição, por parte de Glissant, uma resposta contundente àquela tensão verificada entre escrita e oralidade típica da situação colonial, porquanto assenta que o discurso (prática oral) enseja a prática da escrita, estabelecendo não o divórcio entre um e outro nível, mas sua harmonia e organicidade, conforme faz questão de registrar: "As duas práticas concorrem para um dado onde não nos certificamos mais do que seja escrita 'pura' nem oralidade transcrita" (GLISSANT, 1990, p. 239). E acaba afirmando, na mesma dicção, que a escrita é uma "provocação da oralidade” (GLISSANT, 1990, p. 239).

E também em Le Discours antillais registra-se esta atitude a partir da reiteração da proposição poética que permeia a obra:

Na conjunção do oral e do escrito, este discurso sobre o discurso tentou adaptar sua
maneira ao seu propósito. Ele se disse em mim como uma melopeia, se repetiu como
um cantochão, estacou como um grande tambor, e por vezes se desenvolveu como o
ardor delgado dos ti-bois [instrumento de bambu] em fundo de caixa (GLISSANT,
1981, p. 452).

Sendo este um exemplo do tipo de fala que levou Chancé (2001, p. 163) a considerar a "hipótese de que o discurso literário, em Édouard Glissant, procura uma posição singular, extremamente delicada, sutil, entre o discurso do mestre [a tradição francesa] e o discurso do histérico, sempre mais próximo do louco que do escrito colonialista", particularmente naquilo que ele contém de inovador e desafiador. A "histeria", nesse sentido, poderia articular-se ao que o próprio Glissant chama de "caos-mundo", uma ruptura das estruturas convencionais e uma liberação total da linguagem, um movimento arrebatador em direção ao novo e à diversidade. Aliás, diversidade como força propulsora deste discurso e sua principal fonte conceitual.

Ao cabo, seria a elaboração de um discurso descentrado e caótico, discurso rizomático de infinitos desdobramentos semânticos, a estratégia de oposição e contestação dos tradicionais discursos de poder mais produtiva e dinâmica, ao mesmo tempo em que fundamentalmente propositiva, posto que investe em novos modos de se perceber noções como cultura, linguagem e identidade, a partir da abrangência da diversidade na "totalidade-mundo". 


\section{O discurso renovador}

O discurso glissantiano, por isso, claramente procura a "renovação de todas as coisas" (GLISSANT, 1997, p. 231), a abertura de horizontes e a participação no imaginário de todas as culturas, para o que concorre multiplicando perspectivas, introduzindo inéditas possibilidades poéticas e criando conceitos próprios, no sentido preciso de (re)ler a realidade com outro olhar.

Ao visitar todas as instâncias que organizam o conceito de cultura - história, língua, religião, formação étnica, repertório mítico... -, como parte do esforço de descoberta da identidade antilhana, Glissant fez do discurso seu campo de ação, onde empreendeu a desconstrução de cada uma delas, para daí lançar as bases de novas noções capazes de traduzir mais apropriadamente o real do contexto sobre o qual se debruça. Mas, além de campo de ação, o discurso é também palco das demandas, anseios, revoltas e expectativas do autor, donde revela-se o caráter "histérico" que lhe atribui Dominique Chancé, tanto por se tratar de um discurso do abalo e da mudança, quanto por se tratar de um discurso que afasta a ideia de unidade em benefício da fragmentação.

De maneira que se poderia ver nessa disposição pela busca identitária empreendida em Le Discours antillais, conforme se tem insistido, uma nova orientação acerca do próprio conceito de identidade, que o pensador martiniquense passa a considerar sob o signo da diversidade.

Esta elaboração discursiva sísmica e irruptiva seria, então, suscetível de ser aproximada do movimento geral que atesta, em Le Discours antillais, uma tentativa por parte do escritor de localizar na fragmentação e na disjunção a potência do "nós" antilhano, sendo a sua afirmação a solução possível, e provavelmente a única segundo Glissant, para a questão identitária suscitada naquele contexto.

Assim, ao fundar um discurso da diversidade, em cujo arcabouço desaparecem sistemas e categorias fixas, o qual consubstancia tanto sua produção crítica (ensaística) quanto literária (ficcional), Glissant fez mais do que resgatar a memória antilhana, despertando a todos para a realidade cultural do mundo contemporâneo, onde está em curso uma nova dinâmica identitária, dinâmica que se baseia no encontro de antigas e novas civilizações, como um longo diálogo entre partes distintas que enfim convivem. 


\section{Capítulo IX: As Antilhas falam ao mundo}

\section{O triplo alicerce}

No prefácio à edição brasileira de Introdução a uma poética da diversidade, a pesquisadora e tradutora Enilce Albergaria Rocha oferece uma síntese precisa da natureza do pensamento glissantiano, através da qual revela sua própria sensibilidade ao sentido da poética do autor, às preocupações e propostas presentes em sua vasta obra, o que sem dúvida constitui um importante passo a ser incorporado à leitura que ora se apresenta, especialmente por assentar alguns aspectos basilares que completam o quadro de análise definido ao longo deste estudo e cuja lembrança desde já valerá cumprir-se:

\footnotetext{
Em sua produção poética, ficcional e ensaística, Glissant discute as forças centrípetas das culturas antilhanas e das Américas marcadas pelo Tráfico de africanos, pelo sistema de plantação e a escravidão, forças que considera determinantes no processo de constituição da identidade cultural de uma grande parte dos povos da América colonizada pela Europa, e marcada pela presença africana. Nessa perspectiva, o autor fornece parâmetros para compreender a complexidade das questões culturais colocadas aos povos historicamente colonizados, e que hoje vivenciam os impactos dos processos de globalização.

Entretanto, sua reflexão transborda o espaço do Caribe e da América da diáspora africana, e, dentro de uma perspectiva supranacional, nos remete à questão do contato entre as culturas, as línguas e as civilizações, na contemporaneidade (ROCHA, 2005, p. 10).
}

Da fala da intérprete destaca-se com maior ênfase o apontamento acerca da correlação entre três decisivos pilares que sustentam as reflexões de Glissant, ou seja, o tráfico negreiro, a escravidão e o sistema da plantação, justamente a partir dos quais o pensador martiniquense avalia os processos de formação cultural nas Antilhas e na América como um todo e que estima fundamentais quanto à constituição identitária em tal contexto. E, de forma nítida, este mesmo trípode conceitual embasa Le Discours antillais, cujo conteúdo efetivamente nutre-se da discussão insistente e reiterada desse tema sob diferentes luzes e pontos de vista, conforme o propósito colocado pelo autor de "acumular em todos os níveis" em busca de apreender a fugidia realidade antilhana.

Em sua obra, Glissant assume que a articulação das três instâncias referidas projeta a rede de sentidos da cultura caribenha, respondendo pela dinâmica das relações humanas na região e também pelas idiossincrasias tanto étnicas quanto linguísticas que expõem o teor mesmo da hibridização ou da "crioulização" ali observada. Daí o lugar privilegiado da imagem do arquipélago no pensamento do escritor, que vê na geografia insular um dado representativo 
do encontro e da partilha (de povos, línguas, costumes, etc.) sob a lógica da diversidade. Nesse sentido, os elementos que caracterizam esta cultura, seus avatares, corresponderiam às marcas e consequências da ação colonial europeia - incluídos choques, violências e traumas consubstanciadas e depuradas na experiência da Relação e transformadas em "ato de sobrevivência", como caracterização que lhe é própria e definidora.

Para o autor, dessa forma, qualquer tentativa de penetração da problemática identitária antilhana deve levar em conta a tríade a partir da qual organizou-se o "ato colonial" gerador daquele povo e daquela cultura particularmente. Todo o esforço que despende para dominar esses polos fundamentais da memória histórica antilhana, por isso, envolve uma "exploração criativa" do passado e do presente da realidade local, passando ela pela desconstrução de antigas categorias e sistemas, paralelamente à proposição de um novo olhar acerca dos fenômenos que caracterizam esta realidade.

Sob esse ponto de vista, o programa identitário desenhado em Le Discours antillais seria ilustrativo do exercício desta "exploração criativa" do contexto antilhano proposta por Glissant, não apenas pelo fato de a obra enfeixar um conjunto de análises as mais variadas relativas a esse objeto, contribuindo para o reestabelecimento da consciência coletiva da comunidade ao conceder-lhe voz simbólica (discurso), mas sobretudo por orientar a construção de um outro sentido de identidade através da pluralidade.

\section{O tráfico negreiro}

O primeiro passo no exame da comutação das três "forças centrípetas" no qual investe o autor aponta para o tráfico negreiro como origem da impossibilidade de sedimentação da consciência histórica do povo antilhano e das rupturas ou disjunções que constituem para ele o quadro de uma "não-história”. Como choque traumático e única experiência comum aos cativos africanos de proveniências, etnias e línguas diversas entre si, o tráfico impôs desde logo uma forma de contato absolutamente precária desses povos com o novo meio para o qual se viram "transplantados", donde resultaram uma percepção interrompida e um conhecimento insuficiente por parte dos membros da comunidade em formação acerca do próprio lugar em que estavam destinados a se estabelecer e ocupar. Glissant (1981, p. 130) identifica nesse fato, então, a raiz da questão identitária antilhana, que estaria vinculada justamente ao descompasso 
na relação entre o entorno (natureza) e o acúmulo de experiências (cultura) no cotidiano do sujeito colonizado, gerando uma espécie de abalo de sua consciência.

Além disso, mas em consonância com os “efeitos" decorridos do tráfico negreiro, outro aspecto relevante assinalado por Glissant refere-se à relação do colonizado com a história, ou melhor, sua percepção da história, a qual se dá ainda em termos de apropriação, pelo sujeito, da realidade do ambiente no qual está inserido e consequente datação desta realidade, ou seja, o estabelecimento de determinada ordem temporal de eventos e fatos que lhe conceda o “argumento de sua consciência” (GLISSANT, 1981, p. 131). Posto que não tenha havido a consolidação de um conhecimento efetivo do seu entorno pelo povo antilhano - como parcela essencial da "dinâmica natureza-cultura" -, este também não pôde desenvolver verdadeiramente uma história, no sentido exato em que esta define a trama complexa de uma cultura (civilização) com seu passado, a forjar assim a noção de memória. Logo, quando se verifica esta situação, o povo colonizado permanece à mercê tanto da periodização quanto da “manipulação concertada da história por detentores de poder"42, portanto não sendo ele próprio a fazer a sua história mas a recebê-la passivamente do colonizador ${ }^{43}$.

Decorre daí a recusa demonstrada pelo autor face à noção de uma História linear e hierarquizada (que grafa com "h" maiúsculo propositalmente). No seu entendimento, "uma das consequências mais terrificantes da colonização será esta concepção unívoca da História, e portanto do poder, que o Ocidente impôs aos povos" (GLISSANT, 1981, p. 159), representativa tão somente da pujança de sua cultura frente aos colonizados. Como forma de contestação, Glissant diz que não é a História fixa e rígida que se observa no Caribe, mas, bem ao contrário, são "histórias diversificadas" que "produzem hoje um outro desvelamento: aquele de sua convergência subterrânea" (GLISSANT, 1981, p. 134).

A diáspora forçada dos povos africanos nas Antilhas, segundo o escritor (1981, p. 134, grifo do autor), engendrou, a despeito de rupturas e falhas, "conjunções de histórias que se fizeram subterraneamente" e que ensinam uma "dimensão insuspeita, porque evidente, do agir humano: a transversalidade", a partir do que fica clara a debilidade da pseudo-cronologia

\footnotetext{
${ }^{42}$ Cf. Ricœur (2007, p. 93), já citado no capítulo II desta pesquisa.

43 "[...] eis em que a busca de identidade torna-se para certos povos incerta e ambígua" (!) (GLISSANT, 1981, p. 158).
} 
imposta pelo colonizador, imprópria a um contexto onde a história se multiplica em "histórias solidárias" que se entrecruzam em extrema relativização ${ }^{44}$.

Para Glissant, a compreensão da autêntica história antilhana, de fato "histórias convergentes" dos povos submetidos à experiência do apresamento e da travessia marítima, passa pela ideia de uma "ligação submarina" 45 fundamental, a qual considera poeticamente:

Eu não traduzo, quanto a mim, esta proposição, senão evocando tantos africanos lastreados com grilhões e lançados por cima da amurada cada vez que um navio negreiro se encontrava perseguido por inimigos e se estimava demasiado fraco para sustentar o combate. Eles semearam nas profundezas os grilhões do invisível. É assim que nós aprendemos, não a transcendência nem o universal sublimado, mas a transversalidade. Nos foi preciso muito tempo para sabê-lo. Nós somos raízes da Relação.

Raízes submarinas: significa dizer derivadas, não implantadas de um só mastro numa só aluvião, mas prolongadas em todos os sentidos de nosso universo por sua rede de ramificações (GLISSANT, 1981, p. 134, grifo do autor).

Assim, fica assentado para o pensador martiniquense que é pela aceitação das “conjunções de histórias” de sua realidade, e não pela subordinação paciente à História imposta, que se franquearia ao povo antilhano o acesso à sua memória histórica redimensionada, em que pese ser a memória o "componente temporal da identidade [...]” (RICCEUR, 2007, p. 94). Nesse caso, a ressignificação do imenso trauma representado pelo tráfico de escravos revelaria a verdade da história antilhana, aclarando sua realidade passada e presente, e principalmente seu devir.

\section{A escravidão}

Seguindo o programa reflexivo de Glissant, o passo seguinte na escalada identitária antilhana se faz na direção da análise do regime de escravidão como eixo das tensões sociopolíticas observadas ao longo do processo de formação histórica daquela sociedade. A investigação da organização desse regime e sua aplicação pelos colonizadores, para o autor, conduz à origem da "especificidade" do povo antilhano, porquanto envolve um modo operatório efetivamente particular e inédito no âmbito do empreendimento colonial europeu, com dramáticas consequências humanitárias.

\footnotetext{
44 "Se bater contra o um da História, para a Relação das histórias, é talvez ao mesmo tempo reencontrar seu tempo verdadeiro e sua identidade: colocar em termos inéditos a questão do poder" (GLISSANT, 1981, p. 159).

${ }^{45} \mathrm{O}$ autor toma esta consideração, conforme explica na "NOTE 2 (sur la transversalité)", subtópico da seção 27 de Le Discours antillais, a partir do comentário do poeta e historiador Braithwate sobre a história caribenha, resumido na frase "The unity is submarine". Cf. Glissant (1981, p. 134).
} 
Ao contrário do observado em outras regiões do mundo, em especial na África e na Ásia, onde o colonizador europeu submetia as populações locais à escravidão como parte do projeto econômico-administrativo destinado aos territórios obtidos, nas Antilhas o procedimento foi bem outro. As ilhas do arquipélago foram primeiramente despovoadas de seus habitantes autóctones (os indígenas chamados Caraíbas, dizimados no decurso da Conquista) para depois serem reocupadas com crescentes levas de africanos. Assim, da associação entre o apresamento, o tráfico e o comércio de escravos negros deriva o povo antilhano.

E esse processo se estendeu para outras porções da América, assinalando uma constituição social sob a égide de "formas fragmentárias e patológicas" (HALL, 2008, p. 313) que caracterizam o sentimento de dispersão e perda provocado pela diáspora e pela escravidão. Daí as diversas abordagens do tema por escritores da região que viram no rigor do sistema colonial o legado de uma "neurose coletiva", ou seja, de um quadro psíquico no qual a sociedade percebe a si mesma como produto de uma violência, e por isso tende a "recalcar" suas lembranças ${ }^{46}$, a negar seu passado ou a nutrir a "repugnância por 'voltar às coisas do passado"" (GLISSANT, 1981, p. 134).

Nascido da captura, do flagelo e da diáspora forçada de seus ancestrais, o povo antilhano não pôde consolidar sua consciência histórica ou conceber sua própria identidade, quando, ao contrário, a história se lhe afigurava dolorosa e os laços de identificação com o passado rompidos.

De sua parte, Glissant considera fundamental revisitar até mesmo este passado traumático e explorar aquilo que a escravidão não toldou, intentando desse modo, como anuncia Hall (2008, p. 313), "não a redescoberta, mas a produção de identidade" e não uma identidade baseada na pesquisa estéril, "mas na re-escritura do passado". Esse propósito, o autor o assume em termos de "reunificação imaginária" (HALL, 2008, p. 313), enquanto ato poético a partir do qual reestabelece os laços identitários do povo antilhano subjacentes ao drama da escravidão, potencializando inclusive aspectos imaginativos ligados à dura realidade desse regime, ao fundar, por exemplo, aquilo que nomeia como "marronnage créateur" ${ }^{47}$, componente criativo da literatura antilhana forjada na "relação das culturas" (GLISSANT, 1990, p. 85).

\footnotetext{
${ }^{46}$ As duas expressões entre aspas que aparecem no trecho foram extraídas da "NOTE 1 (sur l'histoire comme névrose)", subtópico da seção 27 de Le Discours antillais. Cf. Glissant (1981, pp. 133-134).

${ }^{47}$ Para uma análise deste aspecto na obra de Glissant, sugerimos a leitura de Suzanne Crosta, Le marronnage créateur: Dynamique textuelle chez Édouard Glissant (1991), indicada nas referências finais.
} 
Se o regime escravista ensejou uma série de rupturas e fragmentações drásticas na relação da sociedade com seu meio e, além disso, se determinou uma "arbitrária hierarquia de raças e por consequência a negação ou a amputação dos povos de origem africana" (CROSTA, 1991, p. 10), impedindo a sedimentação da consciência coletiva do povo antilhano, pode-se afirmar concretamente que Glissant buscou em sua "intenção" poética restaurar "uma plenitude, uma completude imaginária" a fim de religar esse povo à "história interrompida de [seu] passado" (HALL, 2008, p. 313), dispondo acessível a identidade cultural que the pertence.

\section{A plantação}

Assim, no raciocínio sustentado, o último vetor das "forças centrípetas” que Enilce A. Rocha detecta na base do pensamento glissantiano como marcas da cultura antilhana corresponde ao sistema da plantação, que vem a ser parte essencial de seu processo de formação. No nível da problemática identitária, a plantação surge como espaço físico propriamente dito de florescimento de elementos de definição cultural, tais como práticas religiosas e manifestações artísticas, hábitos e costumes partilhados. Acerca desse aspecto, especialmente, pronuncia-se Stuart Hall na seguinte dicção:

O paradoxo é que precisamente o desenraizamento da escravidão e da deportação, e a integração na economia da plantação (e na economia simbólica) do mundo ocidental, que "unificou" esses povos para além de suas diferenças, ao mesmo tempo que lhes tiravam toda possibilidade de alcançar seu passado (HALL, 2008, p. 316).

Ora, o espaço da plantação, núcleo da economia agrícola colonial e principal sorvedouro da mão-de-obra escrava, desempenhou um papel decisivo, ainda que paradoxal, no sentido de integração dos cativos a um modo de vida comum e a um "arranjo" cultural que os unia a despeito de suas diferenças, pois que "os escravos eram também oriundos de tribos, de países, de aldeias diferentes; eles possuíam línguas e deuses diferentes” (HALL, 2008, p. 316). A ideia de "unificação", tal como aparece em Hall, não supõe todavia um apagamento das diferenças (idiossincrasias) entre os africanos deportados para o Caribe, mas aponta diretamente para o processo de "crioulização" desses povos e para a elaboração gradual da chamada "cultura de sobrevivência" que lhes garantiram a comunicação linguística, o intercâmbio étnico e um quadro de vida minimamente estável fora de sua comunidade perdida. Daí Glissant (1990, p. 89) ver a plantação como "berço da crioulização", "uma parte, medida, da lição do mundo".

À plantação o autor atribui o grau de microcosmo da diversidade que veio a se constituir como matéria mesma da modernidade, considerando-a como ambiente produtor do 
imaginário das culturas, não apenas da cultura antilhana, mas de todas as culturas que se encontram (e dialogam) na "totalidade-mundo". Na sua visão, trata-se de um lugar que, embora fechado, projeta uma abertura maximamente produtiva para o mundo exterior, dado que concentra os principais dados em discussão na contemporaneidade:

É na Plantação que, como num laboratório, nós vemos o mais evidentemente em obra
as forças confrontadas do oral e do escrito, uma das problemáticas mais enraizadas
em nossa paisagem contemporânea. É lá que o multilinguismo, esta dimensão
ameaçada de nosso universo, por uma das primeiras vezes constatáveis, se fez e se
desfez de maneira orgânica. É ainda na Plantação que o encontro das culturas se
manifestou com a maior acuidade diretamente observável, ainda que nenhum daqueles
que a habitaram tenha tido a menor desconfiança de que se tratava verdadeiramente
de um choque de culturas. A mestiçagem cultural que nos ocupa a todos, nós podemos
surpreender lá algumas de suas leis de formação. É nos prolongamentos da Plantação,
naquilo que ela pariu no momento mesmo em que desaparecia como entidade
funcional, que se impôs para nós a pesquisa de historicidade, esta conjunção da paixão
de se definir e da obsessão do tempo, que é também uma das ambições das literaturas
modernas (GLISSANT, 1990, p. 89).

Destarte, verifica-se que a plantação figura de fato e direito, na poética glissantiana, como "ventre" da cultura antilhana, na medida exata em que esse espaço sustentou o processo de "crioulização" que concorreu para a formação de um povo e abrigou as formas de seu imaginário, sendo por isso caracterizada pelo escritor como território da identidade dessa comunidade. Mas, paralelamente, também como plataforma para novos modos de percepção cultural e identitária nos dias atuais.

\section{Para além da experiência insular, o imaginário das culturas}

Desse derradeiro apontamento, ademais, pode-se extrair a lição geral do pensamento de Glissant, onde a questão antilhana ela mesma suscita e inspira um novo olhar voltado à realidade contemporânea, onde a "anomalia" do quadro de sua história contribui para o entendimento de situações semelhantes vis-à-vis da modernidade (GLISSANT, 1990, p. 88), transbordando assim o alcance de sua análise o "espaço do Caribe e da América da diáspora africana", no dizer de Enilce A. Rocha.

E, no que concerne a essa espécie de duplo movimento, das Antilhas para o mundo, o autor demonstra sua visão profética, conforme permanece registrado em Le Dicours antillais:

Uma realidade que foi muito tempo não evidente a ela mesma e que tomou corpo em qualquer sorte ao lado da consciência que os povos tinham é da competência tanto da problemática exploratória quanto da planificação histórica. É esta implicação "literária" que orienta o fulcro da reflexão histórica, da qual nenhum dentre nós pode pretender estar salvo (GLISSANT, 1981, p. 133). 
Assim, no trabalho da linguagem, na elaboração discursiva, na construção poética como possibilidades de expandir o imaginário das culturas, Glissant oferece sua contribuição à discussão das identidades na contemporaneidade, quando a abordagem dessa questão muito peculiar ao contexto antilhano veio produzir para o autor um entendimento que se projeta para além da experiência insular, atingindo a "totalidade-mundo" e repercutindo na afirmação da diversidade.

O que se observa então, no caso do projeto literário de Édouard Glissant, é o empreendimento de uma viagem de descoberta e invenção, na qual visita diferentes instâncias do conhecimento para descortinar perspectivas outras, originais e dinâmicas, no sentido de desvelar a realidade das culturas e das identidades, auxiliando as coletividades em sua própria jornada rumo à Relação.

As atribuições da literatura nesse âmbito e suas conquistas para a realização das aspirações poéticas do escritor martiniquense, como etapa concludente desse complexo processo, serão vistas a seguir, onde espera-se atingir a ideia de completude acerca da proposta reflexiva que norteou esta pesquisa. 


\section{Capítulo X: A conquista da Literatura}

\section{O enigma}

A historiografia registra a importância de Aimé Césaire, poeta, ensaísta e político martiniquense, na formação da moderna literatura antilhana de língua francesa, concedendo ao seu principal trabalho, Cahier d'un retour au pays natal (1944), o grau de legado coletivo da intelectualidade caribenha. É nesta obra, precisamente, que pela primeira vez se formula a questão fundamental acerca da identidade cultural nas Antilhas, o que ocorre de modo arrebatador: "Quem e quais nós somos? Admirável questão!” (1983, p. 28). Ao expor esta indagação, Césaire vai além da sondagem ontológica do ser, perscrutando séculos de carência identitária sofrida pelos povos africanos dispersos no Novo Mundo, ao mesmo tempo em que traz à tona o drama humanitário aí implicado. Na raiz do problema, está também enunciado o processo de formação étnica e linguística da comunidade antilhana e suas implicações no modo de representação e identificação do sujeito colonizado com determinados valores e aspectos da realidade na qual está inserido, de sorte que a pesquisa de identidade neste contexto logo transformou-se em luta por reconhecimento e emancipação, com mérito para a ação de escritores e intelectuais da região.

Desde então, na quase totalidade das expressões literárias caribenhas têm sido discutidos meios de afirmação identitária, os quais seguem basicamente os eixos que Pierre Rivas (2005, p. 239) define como "próprios das culturas 'periféricas' (oposição do litoral e do interior; do escrito e do oral; da língua e da tradição; do cosmopolitismo e do enraizamento, etc.)" e visam traduzir uma possível "consciência coletiva". Esta literatura emergente, então, tende a aprofundar o debate acerca das noções de pertencimento e memória como dados de identificação cultural, ao mesmo tempo em que procura pensar as identidades sob a ótica da multiplicidade e da abertura, propondo "não mais um fixismo identitário, mas um 'hibridismo' cultural, linguístico e literário [...]" (RIVAS, 2005, p. 242). Trata-se, por isso, de um processo paralelo, em que a construção identitária passa pela conquista do espaço literário, tornado território de uma "diversidade fragmentada" que é análoga à realidade local, onde se encontram e entremeiam diferentes culturas.

Nesse sentido, é notável o fato de a literatura ter sido mobilizada como veículo da pesquisa identitária, constituindo-se como frente principal dos esforços pela afirmação da 
cultura antilhana em sua diversidade e originalidade. No que se refere a Glissant, particularmente, o tratamento desta questão se apresenta sob a forma de uma dupla interpretação. Num primeiro momento, o autor concentra-se em explorar o "real" de sua comunidade, no intuito de franquear ao povo antilhano o acesso à sua identidade cultural, em que pese a publicação de Le Discours antillais. Já num segundo momento, o escritor introduz o cenário caribenho como paradigma de um movimento global em curso, onde são construídas novas identidades a partir do contato intercultural, valendo a recordação dos conceitos de "crioulização" e "mundialidade" inaugurados em obras como Introdução a uma poética da diversidade e Traité du Tout-monde.

\section{A busca}

Em Glissant, a tentativa de resolução da problemática identitária antilhana e o programa reflexivo que se organiza ao seu redor estão vinculados a uma proposta poética inovadora e a um projeto literário fundamentalmente amplo, como a confirmar os laços orgânicos existentes entre a composição de um espaço autoral e a formação de uma consciência coletiva. Isso porque, nos dois planos, está colocada a incontornável urgência de legitimação que, conforme visto, surge para o autor como uma espécie de força motriz, como uma exigência a partir da qual se estabeleceram seu itinerário filosófico e seu pensamento. Nessa ótica, não seria exagero conceber o complexo literário glissantiano como resultado de uma busca, isto é, a busca pela identidade, onde cada pedra assentada representa um avanço em direção a essa demanda e, sobretudo, um aditivo à sua consolidação.

O que está em jogo, nesse caso, é verdadeiramente um trabalho pela "afirmação de um campo literário antilhano autônomo" (BONNET, 2001, p. 147) e adequado à representação da identidade que se vai redescobrindo e firmando naquele meio. Glissant, nesse processo, desempenhou um papel que poderia ser referido como de liderança, sem dúvida ao menos de referência, ao reunir uma ampla gama de conhecimentos e ao assumir destacado ativismo político frente aos impasses de sua comunidade de origem, onde, a bem dizer, a dimensão sociopolítica envolve e penetra todas as demais, inclusive a literária. A literatura, como projeto identitário, constitui a forma mais remota de reivindicação na região e não deixa de ser também 
a mais eloquente, com especial ênfase sobre a poesia, por razões de alcance ideológico, apelo sensível e veiculação ${ }^{48}$.

De tal maneira que, naquilo que responde propriamente pela busca identitária, acentuase um movimento geral e dinâmico de apropriação do universo cultural antilhano conduzido pelos agentes da nova literatura ali produzida, em que se assiste a uma intensa pesquisa historiográfica, a uma ação empenhada pela redescoberta das tradições crioulas ancestrais, com vistas a uma compreensão mais autêntica dos saberes, mitos e crenças da sociedade local. E basta observar, a esse propósito, os muitos ciclos identitários na produção ficcional caribenha, como em Glissant, Condé e Pineau, por exemplo.

A literatura, neste contexto particular, seria um outro ponto de intersecção no quadro orgânico das relações entre língua, cultura e identidade, com o traço extra de "combate e de afirmação identitária" (RIVAS, 2005, p. 241) que é peculiar às regiões emergentes. Nas Antilhas, assim como na maioria dos territórios saídos da situação colonial em meados do século passado, a literatura constituiu-se num meio de reapropriação dos valores culturais extraviados durante suas tragédias históricas, à maneira da escravidão, das diásporas e ocupações, valores estes que compõem um mapa daquilo que Glissant entende como "depossessão", ou seja, a perda compulsória dos liames que sustentam a memória coletiva, o impedimento da sedimentação do sentimento de pertencimento ao lugar, ao grupo, à sociedade.

O desenvolvimento literário, sob tais condições, nasceria então, de acordo com Pierre Rivas (2005, p. 239) “com a necessidade de exprimir um universo semiótico irredutível (um ecossistema específico, uma outra maneira de apreender o espaço e o tempo, produtos indígenas até então 'inominados')". Seria, em outras palavras, parte de uma iniciativa que visa dirimir a fratura existente na temporalidade e espacialidade do colonizado, que se constata entre natureza e cultura, entre oralidade e escrita, e lança sombra à sua busca por identidade.

\footnotetext{
${ }^{48}$ Como ocorreu, de resto, no período de emergência do próprio conceito de "nação", na Europa, em finais do século XVIII. Recordemos, a esse propósito, que a noção mesma de "nação", como construção histórica, envolveu a ideia de partilha de elementos simbólicos como língua, religião e tradições pelos membros de uma comunidade situada no interior de um território político. Ora, este processo se deu no mesmo momento em que surgia o Romantismo, movimento estético-filosófico fortemente comprometido com um projeto de construção identitária nacional, para o qual a literatura, e mais significativamente a poesia, foi mobilizada com grande empenho.
} 


\section{A Literatura}

Mas são as próprias condições em que surge esta literatura antilhana (literatura emergente, literatura pós-colonial) que é preciso examinar, valendo aqui, por oportuno, recuperar a fala de Raphaël Confiant (1994, p. 172): "Em qual lugar se elabora a literatura antilhana? Sobre qual torrão ela toma apoio? De que matriz ela jorra?’. Para responder a esta questão, não apenas a consideração da conjuntura histórica, já bastante essencial, mas mais precisamente, dos vínculos entre o contexto sociocultural e a produção literária se faz indispensável. Porque, afinal, é o dado posto da contestação e da luta pela emancipação, guardado o evidente protagonismo da problemática identitária, que pontua o ritmo desta literatura, seus movimentos e contramovimentos complementares, assentando sua associação, como quer Antonio Candido (1989, p. 154), “ao começo da capacidade de inovar no plano da expressão e ao desígnio de lutar no plano do desenvolvimento econômico e político".

Inicialmente, cumpre registrar que todo programa de desenvolvimento literário nas Antilhas passa pela matéria da linguagem, aceito que justamente esta "define a idiossincrasia de uma literatura" (RIVAS, 2005, p. 239). Assim, este programa de desenvolvimento está de antemão implicado na zona de tensão entre dois polos: a literatura antilhana se estabelece, de um lado, em face da diglossia, de outro, em face da escrita. Aí se manifesta o dilema do escritor colonial, que deve se haver num primeiro momento com a escolha de uma língua e depois com a tarefa mesma da escrita, dupla herança de uma divisão artificial imposta na realidade de uma cultura oral. Sobre isso fala Raphaël Confiant, que interpreta a questão a partir da leitura de $L e$ Discours antillais, onde Glissant assinala a existência de "um vazio, até mesmo de um abismo, entre o escrito antilhano, seja em francês ou em crioulo, e aquilo que nomeamos doravante oralitura, isto é, o conjunto de práticas linguageiras codificadas (contos, advinhas, cantos de trabalho, etc.)" (CONFIANT, 1994, p. 171).

Em sua análise, Confiant se detém sobre o lapso entre as chamadas "práticas linguageiras", relativas ao uso da linguagem oral, e a prática da escrita literária, que considera em termos de ausência, a ausência de "qualquer passarela" (CONFIANT, 1994, p. 172) a conectar um e outro nível de registro. Trata-se da mesma constatação de "vazio" (béance) feita por Glissant, um espaço não trilhado que produz desvios e saltos improváveis, "espaço de atrito de duas línguas, de dois imaginários, de duas semióticas tão estreitamente mescladas que embaralha as pistas do pesquisador e complica a tarefa deste prático da escrita que é o escritor" (CONFIANT, 1994, p. 172). Nesse âmbito, o autor avalia o processo de formação da maior 
parte das literaturas nacionais, as quais se constituíram a partir de uma "lenta transcrição de falas" (CONFIANT, 1994, pp. 171-172), por diferentes agentes, de modo tal que se estabelecesse um corredor seguro, uma via de passagem equilibrada e livre de traumas entre a oralidade e a escrita. O que não ocorre na sociedade antilhana, formada numa base multiétnica e multilíngue, com a soma de povos ágrafos de origem africana, onde a escrita, na qualidade de legado estrangeiro, não encontra firmados os mesmos laços simbióticos no plano da linguagem oral $^{49}$.

Dois aspectos práticos deste descompasso entre as dimensões da oralidade e da escrita são desde logo assumidos por Glissant e Confiant a título de exame, o primeiro correspondendo a temporalidade e o segundo a descrição. Diz Glissant (1994, p. 122) que o tempo em que opera a narrativa oral ancestral não é o mesmo tempo da narrativa escrita consagrada no Ocidente: "nossa concepção de tempo não é aquela linear do tempo ocidental - malgrado nossas assimilações", algo que tem implicações no modo de percepção da realidade em torno, dos aspectos da vida comum, expressa na relação entre tempo natural e tempo cultural propriamente dita. E o autor acrescenta: "Nós temos, por exemplo, nos países do Caribe, os países crioulos, um tempo natural que não é o tempo cultural do Ocidente" (GLISSANT, 1994, p. 122), acentuando as consequências desse contraste no fazer literário. Já Confiant (1994, p. 172) prefere concentrar-se "na ausência de vocabulário descritivo" em crioulo ao abordar as diferenças de escrita nesta língua e em francês, servindo-se de sua experiência pessoal.

O autor considera duas dificuldades nesse caso: a carência de léxico descritivo em crioulo, que atribui ao caráter eminentemente rural da língua ${ }^{50}$, oriunda do universo da plantação; e o desafio de descrever em francês imagens e objetos já esgotados pelo discurso literário europeu. Dificuldades estas que não deixaram de ter significativa repercussão no processo de desenvolvimento da literatura antilhana, onde se apresentam de maneira objetiva em termos linguísticos, psicológicos, criativos, de sociologia da leitura, etc.

\footnotetext{
${ }^{49}$ Ralph Ludwig (1994, p. 15, grifo nosso) considera que nesta situação particular reside o "impulso" da literatura antilhana: "O arquipélago é o lugar de contato e de confrontação entre o mundo europeu do escrito, da alfabetização e das tradições literárias, de um lado, e o mundo da oralidade, da língua crioula, do contista, da festa popular, de outro. É da análise deste aspecto particular da situação cultual - a clivagem entre escrituralidade francesa e oralidade crioula - que procede a força motriz da literatura antilhana".

50 “".... a língua crioula, essencialmente rural e oral, não possui nível descritivo. Sabemos que não existe sociedade onde o camponês se extasie com a beleza de uma árvore, de uma paisagem ou de um rio (falo de um ponto de vista estético, obviamente, e não produtivo). Vivendo em simbiose estreita com seu meio, ele não precisa estetizá-lo de maneira verbal, escritural ou pictural" (CONFIANT, 1994, p. 172).
} 
Para aprofundar o debate assim ensejado, convém não obstante ouvir o próprio autor em seu testemunho, pelo que resta exposta parte de uma discussão fundamental à formação literária caribenha:

\begin{abstract}
Passado ao francês, [...] tive a surpresa de me encontrar confrontado a um problema similar [àquele da falta de vocabulário descritivo em crioulo], ainda que em termos completamente diferentes. Como descrever um coqueiro? Como dizer que uma praia de areia branca é bela? Coqueiro e areia branca, toda a paisagem antilhana afinal de contas, foram reificados pelo discurso exótico europeu. Um escritor euro-americano pode exaltar a beleza de um pinheiro ou da neve, um escritor antilhano não pode fazer o mesmo pelo coqueiro e pela praia de areia branca. E o drama, para mim, escritor antilhano, é que nem o coqueiro nem a praia de areia branca são exóticas na minha vida cotidiana mas, desde o instante em que, usando da língua francesa, me pego a evocá-los, eu me encontro literalmente refém, aterrorizado no sentido etimológico do termo, pelo olhar reificante do Ocidente (CONFIANT, 1994, p. 173).
\end{abstract}

Confiant enuncia no trecho destacado uma dificuldade de escrita central no desenvolvimento da literatura antilhana, a qual corresponde precisamente a "um problema linguístico no nível do crioulo e um problema semiótico no nível do francês", quando nenhuma das duas línguas chega a satisfazer o desejo do escritor "de dizer o real antilhano, as rochas, as colinas, os trabalhos e os dias" (CONFIANT, 1994, p. 174). Trata-se de uma dificuldade que repercute na localização desta literatura em um campo de expressão definido, portanto em sua própria identificação e "pertencimento" sociocultural.

Sendo que, por trás da relação desta literatura com a oralidade e da problemática linguística envolvida, há um fator mais decisivo ainda, aquele que o escritor associa à semiótica e que corresponde à "convergência de dois sistemas culturais diferentes", donde deriva seu "espírito plural, heteróclito e conflituoso" (RIVAS, 2005, p. 268). Daí o porquê de a preocupação com a autenticidade ser constante nesse contexto e a busca pela ancoragem num campo literário emancipado acompanhar com insistência a busca identitária.

A preocupação com a autenticidade, conforme expõe Confiant, deve-se à necessidade do resgate da realidade local por meio de uma escrita que, quando em crioulo, seja suficiente para transmitir suas propriedades, quando em francês, não esteja contaminada pelos lugarescomuns do discurso exótico europeu. Isso porque, diante do olhar ocidental, as demais culturas figuram como "exóticas", acontecendo de o discurso, tanto científico quanto artístico, concorrer para disciplinar esta característica, submetendo-a a categorias tais como o exotismo, o orientalismo, etc.

O desafio do escritor colonial seria, então, enfrentar as tópicas artificiais criadas a partir dessas categorias e simplesmente mimetizadas e repetidas, o que caracteriza um 
verdadeiro esforço semiótico pela absorção da realidade ocultada sob aquele discurso. Esforço que se traduz, enfim, na pesquisa por novas fontes de inspiração e conhecimento que venham renovar a prática da escrita e consubstanciar o fazer literário em sua potencialidade expressiva.

No caso das Antilhas, Glissant interpreta a potencialidade a partir do imaginário da plantação, que o pensador define através da admirável imagem do "lugar fechado, palavra aberta", um sistema que "organiza o ritmo da produção econômica e funda um estilo de vida" capaz de ser partilhado em "regiões linguisticamente tão diferenciadas, engajadas em dinâmicas políticas tão divergentes” (GLISSANT, 1990, p. 77). O sistema da plantação, transfigurado em imaginário cultural, estimulou expressões artísticas autênticas no seio da sociedade caribenha multiétnica, como representação dinâmica da antilhanidade latente:

Compreendemos que está aí um universo onde todo grito faz evento. [...] De um lado a outro desse mundo, a melopeia, sincopada, picada por interditos, liberada por todo o impulso dos corpos, produz sua linguagem. Essas músicas nascidas do silêncio, negro spirituals e blues, continuados nos burgos e cidades crescentes, jazz, biguines e calypsos, estourados nos barrios e favelas, salsas e reggaes, reúnem em uma fala diversificada aquilo que era secamente direto, dolorosamente engolido, pacientemente diferenciado. Elas são o grito da Plantação, transfiguradas em fala do mundo (GLISSANT, 1990, p. 88).

Aqui está presente a ideia de uma identidade literária antilhana comum e superposta à diversidade geopolítica, étnica e linguística das ilhas caribenhas e de suas comunidades, configurada a partir de experiências compartilhadas por seus membros e convertidas num estilo de vida específico. Nesse sentido, a noção de um espaço de contato intercultural, que desde logo identifica-se ao arquipélago, representa para a literatura do Caribe um "conjunto de realidades trans ou supranacionais, em estruturas concêntricas" (RIVAS, 2005, p. 238).

A literatura da região, assim, bem poderia ser definida como literatura de cultura, superior às noções restritas de nacionalidade ou de língua de expressão ${ }^{51}$, literatura cuja identidade é multifacetada e cujo campo particular se constrói no próprio imaginário comungado pelos membros dessa cultura. Enfim, literatura "franco-hispano-holandesa-inglesa de que se encontrará em Glissant, por exemplo, uma primeira profecia” (RIVAS, 2005, p. 238).

\footnotetext{
${ }^{51}$ Acerca desse aspecto, citemos o comentário provocador de Pierre Rivas (2005, p. 237): “A ideia de que uma literatura nacional deva exprimir-se em uma língua nacional una, é ela mesma uma ideia histórica, como, de resto, as ideias de nação, de língua nacional e a própria ideia de literatura. [...] Lembraremos que, na Idade Média, é o gênero literário, não a nacionalidade do autor, que leva à escolha de uma língua, por exemplo o provençal e o galaico-português para a lírica; as distribuições linguísticas não coincidem com conjuntos políticos, que elas transcendem ou fragmentam. É evidente que uma literatura não se identifica com uma língua ou uma nação [...]".
} 


\section{A conquista}

É curioso observar que, ao cabo, a literatura antilhana, em sua dupla exigência (por identidade e por um campo próprio), tenha acabado por encontrar suas demandas no sentido mesmo da "crioulização", isto é, num hibridismo tanto linguístico quanto étnico, como tradução da multiplicidade identitária antilhana, sendo desenvolvida no entremeio insular, num plano que transcende as fronteiras nacionais, conforme admite o próprio escritor em nota de Le Discours antillais ${ }^{52}$ : “Os encontros entre as literaturas antilhanas (anglófona, francófona, hispanófona, crioula) não provêm de uma decisão dos produtores de textos; são os efeitos ainda camuflados de um mesmo movimento histórico, de um mesmo pertencimento cultural" (GLISSANT, 1981, p. 130).

Nas Antilhas, segundo Glissant (1990, p. 85), a literatura é forjada na "relação das culturas", e valeria acrescentar que também na "relação das poéticas" que desenham sua consciência humana e estética, pelo que o autor lhe atribui três momentos de produção contundentes: "como ato de sobrevivência inicialmente, como embuste em seguida, como esforço ou paixão da memória, enfim" (GLISSANT, 1990, p. 82). Três momentos que se acordam, respectivamente, ao descontínuo da oralidade crioula, ao fulgor criativo e à "imersão do psicológico no drama do devir comum" (GLISSANT, 1990, p. 85), conforme um movimento de transformação do discurso e de renovação semiótica.

A literatura antilhana plurilíngue, crioula, encontra, destarte, na diversidade a sua matéria conceitual, responsável por identificá-la, e no arquipélago seu "espaço de expressão" (PAGEAUX, 2011, p. 30), o perímetro no qual se manifesta, compondo uma região de influência. E, nesse âmbito, repetindo a concepção de Pageaux (2011, p. 25), trata-se de uma literatura que pressupõe que a "multiplicidade não venha a abolir a singularidade", ou seja, que a afirmação do diverso nesse campo literário e que sua realização, ela mesma culturalmente diversificada, não significam uma diluição das particularidades, porém, ao contrário, acentuam a importância do respeito à subjetividade e à outridão ${ }^{53}$. De sorte que, neste estro de espírito que expande a pluralidade, tal literatura postula "uma noção aberta, plural, dinâmica, de identidade, não como núcleo duro, mas como casca de cebola, mosaico, rosa-dos-ventos, identidade heteronímica [...]" (RIVAS, 2005, p. 238).

\footnotetext{
${ }^{52}$ Cf. nota 1 da página indicada.

${ }^{53} \mathrm{O}$ termo é aqui empregado no sentido de uma "compreensão da alteridade como emergência, ou seja, do processo que leva do outro-mundo-circundante ao outro objetivado na sua alteridade", tal como propõe Figueiredo (1998, p. 73, grifo do autor).
} 
Poder-se-ia talvez intuir da obra glissantiana a emanação primeira deste sentimento (a)colhido pelos autores da literatura antilhana: a posse da paisagem, a fundação de um discurso autêntico (seja em francês ou em crioulo), a introdução à Relação das culturas, o diálogo e a partilha. Tal como aparece em Le Discours antillais, a experiência cultural e literária antilhana promoveu uma incomparável mudança, não outra que a passagem "do universo transcendental do Mesmo imposto [...] pelo Ocidente ao conjunto difratado do Diverso [...]" (GLISSANT, 1981, p. 190), contribuindo assim para a transformação positiva da civilização e para a descentralização ideológica do mundo.

Ao empreender a tarefa de responder ao enigma de sua identidade, os autores da literatura antilhana trouxeram, no retorno da Errância e da Margem $^{54}$, novos aportes para se pensar esta noção que vem sendo desconstruída na contemporaneidade, porquanto "Quem e quais nós somos?" deriva de um questionamento maior que atravessa os limites das culturas, como gesto de compreensão ou convite à descoberta que supera tensões e dilemas identitários, pensando-se em relação ao seu próprio sentido. Eis a conquista alcançada.

54 "Não mais o enraizamento identitário nacional, mas Errância e Margem (à imagem do escritor da periferia, latino-americano ou africano, condenado ao exílio pelas tragédias de sua história nacional)" (RIVAS, 2005, p. 241). 


\section{Conclusão}

Nas preliminares desta pesquisa, objetivou-se proceder ao exame do modo como a questão identitária, presente factualmente na realidade antilhana, aparece na obra de Édouard Glissant Le Discours antillais e como o autor a trata, isto é, de que maneira interpreta esta problemática e quais recursos mobiliza para discuti-la, tendo em vista sobretudo a constatação do papel fundamental que desempenha na própria constituição do pensamento e do projeto literário do autor esse tema. Sobre a escolha de Le Discours antillais, nesse caso, seria bastante considerar que se trata de um dos principais trabalhos do escritor martiniquense e sumamente representativo de sua poética, naquilo que ela concentra de mais importante. Além disso, poderse-ia acrescentar que o volume culmina no esforço mais significativo pela apreensão do real antilhano, pela redescoberta da memória e da identidade de uma cultura, donde a relevância de se observar ali, talvez mais que em qualquer outra produção, o exercício crítico de Glissant.

Em consideração ao contexto histórico, político e social das Antilhas e ao lugar de destaque que ocupa a pesquisa de identidade na região, privilegiou-se uma abordagem analítica aberta e interdisciplinar, a partir da qual fosse possível oferecer uma leitura original e em qualquer sorte inovadora sobre o assunto focado, no que contribuíram as perspectivas oferecidas pela linguística, pela sociologia, pela teoria literária, pelos estudos pós-coloniais e pelos cultural studies. A análise também se fez à luz dos conceitos que organizam o pensamento glissantiano e de trabalhos de outros autores e intelectuais do cenário caribenho, aos quais se recorreu sempre que preciso para melhor ilustrar o quadro da situação descrita.

Já a organização e distribuição dos capítulos foi estabelecida no sentido da coerência e da progressão dos termos acordados no estudo, com um esclarecimento contínuo e regular acerca da problemática instaurada, desde a apresentação das noções basilares de língua, cultura e identidade, passando pela contextualização da formação histórica da sociedade antilhana, pelas frentes de reflexão acerca da questão identitária, pela constituição cultural crioula, pela ideia de "identidades plurais", pela ação política do autor, pela disposição do programa identitário levado a cabo em Le Discours antillais, pelo sentido do "discurso da diversidade", pelo alcance da proposta poética de Glissant (das Antilhas para a "totalidade-mundo"), até as considerações sobre o caráter da literatura antilhana e seu papel na afirmação da relação das culturas. 
Assim, foi visto inicialmente que a noção de cultura está em permanente evolução através das épocas e não se restringe a um sentido único, mas admite diferentes argumentos em sua definição; que a língua é veículo da cultura e possui um vetor social fundamental, e que a partir da complexa associação entre língua e cultura projeta-se a ideia mesma de identidade, da qual participam diversos outros elementos. Além disso, as identidades também deixaram de ser dados fixos e passaram a assumir feições cambiantes, o que se reflete na modernidade, conforme aponta Stuart Hall (2006, p. 07), como uma verdadeira crise, "que é vista como parte de um processo mais amplo de mudança, que está deslocando as estruturas e processos centrais das sociedades modernas $[\ldots]$ "..

Ora, seguindo esse raciocínio, chega-se a perceber que particularmente no âmbito das liberações coloniais de meados do século XX o problema identitário colocou-se com grande força, expondo dramas linguísticos, traumas históricos, impossibilidade de sedimentação da memória coletiva etc., o que ensejou debates sobre novas perspectivas acerca do conceito, com demandas e proposições que abasteceram toda uma literatura. Nesse âmbito, a busca pela própria identidade cultural envolveu um movimento paralelo de contestação do "enraizamento identitário nacional" (RIVAS, 2005, p. 241), tal como surge no Ocidente, em favor da afirmação de identidades heterogêneas e rizomáticas, as quais representariam uma relação aberta à alteridade e à diversidade.

No que tange às Antilhas, a questão identitária, conforme tratado, remonta ao período da ocupação europeia, quando a conjuntura tráfico negreiro-escravidão-plantação originou uma comunidade multiétnica e multilíngue carente de laços com seu entorno, de temporalidade e de consciência histórica. Sob tais condições organizou-se, como propõe Dahomay, uma "cultura da sobrevivência" baseada na hibridização de elementos de diversas proveniências, a qual é igualmente referida como cultura crioula, que permitiu aos seus membros, ainda que precariamente, "[refundar] o mundo e [reorganizar] uma certa instituição simbólica do social" (DAHOMAY, 2000, p. 101). De modo que nesse arranjo reside a especificidade do "caso antilhano", onde a configuração daquela comunidade resultou de um choque entre dois mundos opostos e da violência implicada na ação colonial, advindo daí a dificuldade de qualquer tentativa de identidade na região.

A partir da mobilização de diferentes fontes e do aprofundamento da leitura de $L e$ Discours antillais, definiu-se que Glissant estabelece sua abordagem dessa questão considerando que as rupturas e disjunções da formação insular constituem uma "não-história", porquanto o povo antilhano não dispôs nenhuma datação de sua realidade, ou seja, nenhuma 
organização temporal de fatos e eventos, mas tão somente aceitou a datação imposta pelos dominadores, submetendo-se assim ao poder de uma cultura outra. Por outro lado, as marcas da diáspora forçada, da dispersão e da escravidão fomentaram a repulsa da sociedade pelo seu próprio passado, que prefere contornar e se possível afastar, o que impede que se crie para ela uma memória coletiva. Sendo que, para o autor, esse painel expõe as deficiências que baldam a busca de identidade para os antilhanos, em que pesem também os processos políticos de assimilação cultural e departamentalização.

Frente a semelhante contexto, a primeira preocupação de Glissant foi firmar sua posição como escritor independente, no que buscou uma formação humanista, reunindo conhecimentos amplos em vários campos disciplinares, na precisa acepção de intelectual total. Em sua atividade poética, procurou cruzar caminhos não trilhados ou percorrer os antigos com novo olhar, desconstruindo sucessivamente as categorias tradicionais do pensamento, com o firme propósito de "descolonizar" territórios do saber como a história, a filosofia, a literatura e as artes, para reorganizá-los num leque mais amplo de sentidos. E por isso questionou o caráter unívoco da História legada pelo ocidente e opôs-se ao primado do eu em defesa do nós, além de propor a Relação e o Diverso como possibilidades inovadoras de interpretação do mundo.

Toda essa elaboração passa, no entanto, pelo crivo da realidade antilhana e pela questão identitária ali suscitada, uma vez que o escritor empreende o questionamento das linhas tradicionais que pretendem a cultura e as identidades como noções fixas justamente porque a experiência de sua comunidade com a diversidade étnica, linguística e cultural aponta numa direção inusitada que exige sua remodelação e transformação. Daí o fato de assumir a história antilhana como uma conjunção de "histórias solidárias", assumir o conceito de rizoma em lugar da raiz única (o mito da origem), assumir a dinâmica do multilinguismo, assumir enfim a relação intercultural na "totalidade-mundo", em atitude que introduz a ideia de culturas compósitas e identidades abertas, não mais a unicidade nem a rigidez. Em tudo isso, portanto, fundamenta-se o pensamento glissantiano acerca da pesquisa de identidade nas Antilhas: pela recuperação ou invenção da(s) história(s), pela ênfase na diversidade, pela liberação do imaginário poético dos povos, pela crença na "crioulização".

Assim, as propostas de Glissant, no sentido da busca identitária, perpassam a crítica do colonialismo, o exame das particularidades da formação da sociedade antilhana, a problemática linguística, culminando na reflexão literária que apresenta em Le Discours antillais, onde explora os mais diversos aspectos do real de sua comunidade, "acumulando em todos os níveis" no intuito de apreendê-la num todo dinâmico e complexo. Conforme se insistiu 
em dizer, esta obra veio conceder ao povo antilhano voz simbólica, expondo as múltiplas facetas de sua cultura e demonstrando que as identidades podem ser pensadas em termos de flexibilidade e partilha, como construção constante e solidária. E como voz simbólica projetou a fala (o canto) do autor, cujo dever seria resgatar a memória e expressar a consciência antilhana, sobretudo contribuir para o restabelecimento da relação orgânica entre natureza e cultura antilhanas.

Em vista das repercussões da questão identitária na literatura antilhana, não se deixou de discutir, na etapa final do presente estudo, os principais aspectos do projeto glissantiano, particularmente naquilo que diz respeito a conquista de um campo literário próprio na região. Foram, então, consideradas as questões principais nesse contexto, a exemplo da relação entre oral e escrito, entre língua francesa e língua crioula, etc., sem perder o horizonte do papel da literatura na afirmação da identidade antilhana. Nesse caso, Glissant prevê a integração em torno de uma literatura antilhana plurilíngue e supranacional, como um "território" onde são partilhados valores comuns e um mesmo imaginário cultural, a refletir não mais do que a própria diversidade ali confirmada. Com isso, o escritor assinala para a potência poética em seu alcance utópico, como possibilidade emancipatória e de participação na Relação.

Também de acordo com aquilo que ficou assentado ao longo da análise desenvolvida, observa-se que as conquistas do autor nesta matéria desbordam o espaço insular caribenho, abrangendo a natureza mesma do "contato entre as culturas, as línguas e as civilizações, na contemporaneidade" (ROCHA, 2005, p. 10). Na sua concepção, as Antilhas estariam na vanguarda de um movimento geral que toma lugar no mundo de hoje, quando as culturas, linguagens e identidades se fazem em processo de "crioulização", pela troca e comunhão de caracteres sem perda da subjetividade e das particularidades. Daí emergindo a grande e duradoura lição de sua obra: "que nos reencontramos para partilhar a cada vez um frêmito, ínfimo ou revelador, físico ou social ou político, da totalidade-terra” (GLISSANT, 1997, p. 183).

Destarte, dentro dos limites da proposta de investigação aqui admitida, conclui-se que o tratamento da questão identitária antilhana em Le Discours antillais se coaduna a uma forma de abordagem inovadora que envolve diferentes frentes e métodos, como revela a estrutura em mosaico dessa obra, formada por transcrições de artigos e conferências, por instantâneos poéticos, depoimentos, reflexões e documentos, num intricado arranjo, sendo que esta forma de abordagem não-linear e irregular projeta o sentido exato da busca empreendida pelo autor, o sentido da acumulação: "a técnica mais apropriada de desvelamento de uma realidade que, ela 
mesma, se dispersa" (GLISSANT, 1981, p. 13). Ao discutir cumulativamente as diferentes instâncias da realidade antilhana, Glissant tornou tangível o que antes era etéreo, apreendeu pelo condão do discurso a cultura flutuante no tempo inacessível de sua "não-história" e dinamizou a visão sobre as identidades através do fazer poético. Nessa tessitura heterogênea, por conseguinte, estiveram implicadas a força criativa do autor, sua capacidade de percorrer os mais diversos assuntos e deles extrair fundamentos para analisar o particular de sua ilha natal, mas sem limitar-se a ela apenas, ajudando a compreender inúmeros aspectos da paisagem contemporânea em fluxo e transformação. 


\section{Referências}

ARTIÈRES, Philippe. "'Solitaire et solidaire'. Entretien avec Édouard Glissant”. Terrain (Poésie et politique), no 41, sep. 2003. Paris: Éditions du patrimoine, 2003, pp. 09-14.

BAKHTIN, Mikhail. Marxismo e filosofia da linguagem. Trad. Michel Lahud e Yara F. Vieira. 8a ed. São Paulo: Editora Hucitec, 1997.

BAUMAN, Zygmunt. Modernidade Líquida. Trad. Plínio Dentzien. Rio de Janeiro: Zahar, 2003. [1 ${ }^{\text {a }}$ ed. orig. 2000].

BHABHA, Homi K. O Local da Cultura. Trad. Myriam Ávila, Eliana L. L. Reis e Gláucia R. Gonçalves. Belo Horizonte: Editora UFMG, 1998.

BERNABÉ, Jean; CHAMOISEAU, Patrick; CONFIANT, Rafaël. Éloge de la créolité. Paris: Gallimard, 1993. [1 ${ }^{\text {a }}$ ed. orig. 1989].

BONNET, Véronique. "Les traces intertextuelles ou l'affirmation d'un champ littéraire francoantillais". In: FONKOUA, Romuald; HALEN, Pierre (dir.). Les champs littéraires africains. Paris: Éditions Karthala, 2001, pp. 135-149.

BOURDIEU, Pierre. Les règles de l'art. Génèse et structure du champ littéraire. Paris: Éditions du Seuil, 1992.

BROWN, Henry D. Teaching by principles: an interactive approach to language pedagogy. Englewood Cliffs: Prentice Hall Regents, 1994.

CANDIDO, Antonio. "Literatura e subdesenvolvimento". In: A educação pela noite e outros ensaios. São Paulo: Ática, 1989, pp. 140-162.

CÉSAIRE, Aimé. Cahier d'un retour au pays natal. Paris: Éditions Présence Africaine, 1983. [1 ${ }^{\mathrm{a}}$ ed. orig. 1947].

CHAMOISEAU, Patrick. Écrire en pays dominé. Paris: Gallimard, 1997.

CHANCÉ, Dominique. L'auteur en souffrance. Col. "Écritures francophones". Paris: PUF, 2000 .

Poétique baroque de la Caraïbe. Paris: Éditions Karthala, 2001.

CLIFFORD, James. Routes: Travel and Translation in the Late Twentieth Century. Cambridge: Harvard University Press, 1997.

CONFIANT, Raphaël. "Questions pratiques d'écriture créole”. In: LUDWIG, Ralph (dir.). Écrire la "parole de nuit". La nouvelle littérature antillaise. Paris: Gallimard, 1994, pp. 171-180.

CROSTA, Suzanne. Le marronage créateur: Dynamique textuelle chez Édouard Glissant. Col. "Essais", no 09. Saint-Foy/Québec: GRELCA, 1991.

CUCHE, Denys. A noção de cultura nas ciências sociais. Trad. Viviane Ribeiro. Bauru: EDUSC, 1999. 
DAHOMAY, Jacki. "Identité culturelle et identité politique. Le cas antillais". In: KYMLICKA, Will; MESURE, Sylvie (dir.). Les identités culturelles. Comprendre: revue de philosophie et de sciences sociales, $\mathrm{n}^{\circ}$ 01, 2000. Paris: Presses Universitaires de France, 2000, pp. 99-118.

DAMATO, Diva B. Édouard Glissant. Poética e Política. São Paulo: Annablume, 1996.

DELEUZE, Gilles; GUATTARI, Félix. "Introdução: Rizoma". In: Mil Platôs.

Capitalismo e Esquizofrenia. 5 Vols. Col. "Trans". Trad. Ana L. de Oliveira, Aurélio Guerra Neto e Célia P. Costa. São Paulo: Editora 34, 1995, v. 1, pp. 10-37.

EAGLETON, Terry. A ideia de cultura. Trad. Sandra C. Branco. São Paulo: Editora da Unesp, 2005.

FANON, Frantz. Pele negra, máscaras brancas. Trad. Renato da Silveira. Pref. Lewis R. Gordon. Salvador: EDUFBA, 2008.

FERGUSON, Charles A. “Diglossia”. Word, vol. 15, 1959, pp. 325-340.

FIGUEIREDO, Luís C. "A questão da alteridade nos processos de subjetivação e o tema do estrangeiro”. In: KOLTAI, Caterina (org.). O estrangeiro. São Paulo: Escuta/Fapesp, 1998, pp. $61-75$.

FONKOUA, Romuald-Blaise. Essai sur une mesure du monde au XXème siècle. Édouard Glissant. Paris: Honoré Champion, 2002.

GLISSANT, Édouard. L’Intention poétique. Poétique II. Paris: Éditions du Seuil, 1969.

Le Discours antillais. Paris: Éditions du Seuil, 1981.

Poétique de la Relation. Poétique III. Paris: Gallimard, 1990.

Tout-monde. Paris: Gallimard, 1993.

. "Le chaos-monde, l'oral et l'écrit". In: LUDWIG, Ralph (dir.). Écrire la "parole de nuit". La nouvelle littérature antillaise. Paris: Gallimard, 1994, pp. 111-129.

Traité du Tout-monde. Poétique IV. Paris: Gallimard, 1997.

Introdução a uma poética da diversidade. Trad. e pref. Enilce Albergaria Rocha. Juiz de Fora: UFJF, 2005. [1 $1^{\text {a }}$ ed. orig. 1995].

Philosophie de la Relation (poésie en étendue). Paris: Gallimard, 2009.

HALL, Stuart. A identidade cultural na pós-modernidade. Trad. Tomaz T. da Silva e Guacira L. Louro. 11 ${ }^{\mathrm{a}}$ ed. Rio de Janeiro: DP \& A Editora, 2006.

"Identité culturelle et diaspora". In: Identités et Cultures. Politiques des cultural studies. Ed. est. por Maxime Cervulle. Trad. do inglês de Christophe Jaquet. Paris: Éditions Amsterdam, 2008. pp. 311-325.

JUMINER, Bertène. "La parole de nuit". In: LUDWIG, Ralph (dir.). Écrire la "parole de nuit". La nouvelle littérature antillaise. Paris: Gallimard, 1994, pp. 131-149. 
KRAMSCH, Claire. Language and Culture. Oxford: Oxford University Press, 1998.

LUDWIG, Ralph (Introd.). In: (dir.). Écrire la "parole de nuit". La nouvelle littérature antillaise. Paris: Gallimard, 1994, pp. 13-25.

MADOU, Jean-Pol. Édouard Glissant. De mémoire d'arbres. Col. "Monografique Rodopi en Littérature Française Contemporaine", vol. XXVI. Amsterdam-Atlanta: Rodopi, 1996.

MEMMI, Albert. Retrato do Colonizado precedido pelo Retrato do Colonizador. Trad. Roland Corbisier e Mariza P. Coelho. Série "Ecumenismo e Humanismo", vol. 11. São Paulo: Paz e Terra, 1967.

PAGEAUX, Daniel-Henri. "Introdução. O comparatismo: entre tradição e renovação". In: Musas na encruzilhada (ensaios de literatura comparada). Org. Marcelo Marinho, Denise A. Silva, Rosani K. Umbach. Vários tradutores. São Paulo: Editora Hucitec/URI/UFSM, 2011, pp. 19-42.

PETTER, Margarida. "Linguagem, Língua, Linguística”. In: FIORIN, José L. (org.). Introdução à Linguística. Vol. I Objetos teóricos. $4^{\mathrm{a}}$ ed. São Paulo: Editora Contexto, 2010, pp. 11-24.

PINEAU, Gisèle. L'Exil selon Julia. Paris: Éditions Stock, 1996.

RADFORD, Daniel. Édouard Glissant. Col. "Poètes d'aujourd'hui”. Paris: Seghers, 1982.

RICCEUR, Paul. A memória, a história, o esquecimento. Trad. Alain François et al. Campinas: Editora da Unicamp, 2007.

RIVAS, Pierre. Diálogos interculturais. São Paulo: Editora Hucitec, 2005.

ROCHA, Enilce A. (Pref. e trad.). Introdução a uma poética da diversidade. Juiz de Fora: UFJF, 2005.

SANTOS, José L. dos. O que é cultura. 16ª ed. São Paulo: Editora Brasiliense, 2006.

SAUSSURE, Ferdinand de. Curso de Linguística Geral. Org. Charles Bally, Albert Sechehaye e Albert Riedlinger. Trad. Antonio Chelini, José Paulo Paes e Izidoro Blikstein. Pref. Isaac N. Salum. $27^{\mathrm{a}}$ ed. São Paulo: Cultrix, 2006.

SCOTT, Joan W. "Multiculturalism and the Politics of Identity". In: RAJCHMAN, John (ed.). The Identity in Question. Nova Iorque/Londres: Routledge, 1995, pp. 03-12.

TULLY, James. "Une étude de la politique de l'identité". In: KYMLICKA, Will; MESURE, Sylvie (dir.). Les identités culturelles. Comprendre: revue de philosophie et de sciences sociales, $\mathrm{n}^{\circ}$ 01, 2000. Paris: Presses Universitaires de France, 2000, pp. 193-218.

UllmanN, Reinholdo A. Antropologia: O Homem e a Cultura. $3^{\text {a }}$ ed. Petrópolis: Vozes, 1991.

VIERTLER, Renate B. "Estudos sobre 'identidade"”. In: LUCENA, Célia T.; GUSMÃO, Neusa M. M. (org.). Discutindo identidades. São Paulo: Humanitas, 2006, pp. 45-55. 